\title{
TURA VERBAL TONOLOGY
}

\author{
Michael R. Marlo \\ University of Maryland
}

This article provides a comprehensive description and analysis of the verbal tone system of Tura, a previously undocumented dialect of Luyia (Bantu, Kenya, J.30). Tura has many tonal Patterns marking tense-aspect-mood-polarity distinctions that are characterized by a grammatical ("melodic") $H$ tone on different positions of the verb stem. The realization of melodic Hs depends on the prosody of the verb stem (number of syllables, syllable weight, C-initial vs. Vinitial) and complex interactions with $\mathrm{H}$-toned prefixes. Some melodic Hs surface whether or not there is a $\mathrm{H}$-toned prefix; others do not surface after a $\mathrm{H}$ toned prefix; and one surfaces only in combination with a H-toned prefix. Some melodic $\mathrm{Hs}$ block the $\mathrm{H}$ of the reflexive from surfacing; others are blocked from surfacing by the reflexive $\mathrm{H}$; and another surfaces along with the reflexive $\mathrm{H}$. The article describes and analyzes these and other cross-melody differences in the Tura tonal system as well as variation between two speakers of the dialect.

* The data provided in this paper come from approximately 19 hours of recorded interviews with two native speakers of Tura in Busia, Kenya in 2006: 10 hours with Jonathon Wabala in May-June, plus 9 hours with Kenneth Okumu in August. This paper could not have been written without their assistance. Alfred Anangwe aided in arranging interviews and, along with Moses Egesa, provided logistical support in the field. I would also like to thank the participants in my Phonology of Tone seminar in Fall 2008 at Indiana University, as well as Kris Ebarb, Larry Hyman, Dave Odden, Mary Paster, Cédric Patin, and an anonymous reviewer for their helpful comments on earlier drafts of this paper. Recorded examples of the Tura data are available online at http://ling.osu.edu/sal/Vol37/Marlo/Tura.zip (400 Mb) in the form of an "audio paradigm archive" of 3 hours 8 minutes of sound files corresponding to the paradigms in this article. Thanks to Cathryn Panganiban and Michelle Perrault for their help in Spring 2008 in creating the archive. Research support leading to this paper was provided by a National Science Foundation Graduate Research Fellowship and National Science Foundation Doctoral Research Improvement Grant 0545246. The usual disclaimers apply. 


\section{Introduction.}

The Tura dialect of Luyia (Bantu, Kenya, J.30) is previously undocumented, mentioned for the first time in the literature on Luyia linguistics in Marlo (2007). The Batura people are found across three political districts in Kenya's Western Province: Busia, Mumias-Butere, and Bungoma, roughly in the area indicated in the map in (1). The size of the Batura ethnic group is presently unknown, although it is certainly smaller than the nearby Khayo community, reported to have 60,000 speakers in a 1980 SIL survey cited on the Ethnologue online.' The main goal of this paper is to provide a comprehensive description and analysis of the Tura verbal tone system, based on data collected from two Tura speakers in Busia, Kenya in 2006.

(1) Map of the Luyia dialect area (adapted from Leung 1991)

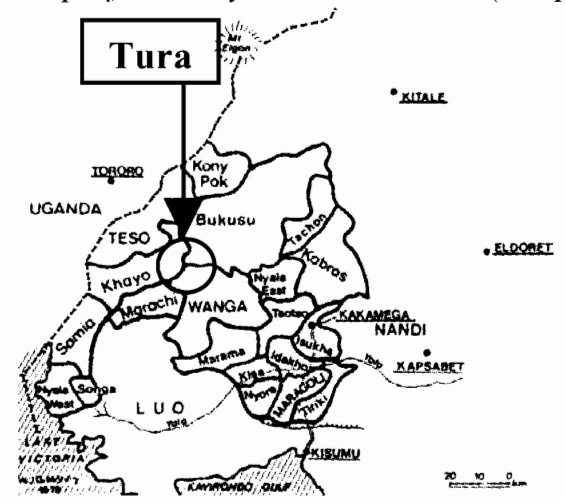

More recent figures are not available, and it is difficult to estimate how the number of speakers has changed since those figures were reported. The population within the Western Province of Kenya has grown considerably over the past 30 years, nearly doubling from 1,832,663 to $3,358,776$ between the 1979 and 1999 censes, but it is not known whether the Turaspeaking community has also grown, or even what it was 30 years ago! Concerning the longterm outlook for the dialect, we note that the children of Kenneth Okumu, a consultant to this project residing in Butura, are learning Tura as their first language, but the percentage of children who are growing up in Tura-speaking areas, learning the dialect, and continuing to use it into adulthood is likely decreasing, possibly significantly. The Batura appear to have existed for some time as a marginalized minority group within Luyia, having never had their own administrative division and even losing land during colonial times to the dominant Wanga ethnic group when Chief Mumia Nabongo was buried in Butura, according to my consultants. 
Considering the relative similarity of their non-tonal phonological systems, the Luyia dialects have remarkably different tonal systems. These are among the most typologically diverse tonal systems in all of Bantu, including tonally conservative dialects such as Logoori, which have a $\mathrm{H}$ vs. Ø lexical constrast in verb roots, tonally reversed dialects such as Marachi, where historically H-toned roots were reanalyzed as L, and tonally predictable dialects such as Tura, which have eliminated the lexical tonal contrast in verb roots (Marlo 2008). There are further tonal differences within these types of tonal systems. In fact, each Luyia dialect whose tonal system has been studied to date has been found to be different, and non-trivial tonal differences have also been found among speakers of the same dialect, as we see in this article.

The present study adds to the relatively small database of languages whose melodic tone systems are extensively described and constitutes the first in a series of studies of Luyia tonal systems by this author. Studies of this type provide the empirical foundation for the future testing of theories of morphologically specific phonology, tonal rules and representations, and language variation and change.

\section{Overview of Tura Tone.}

Verbal tone in Tura is most similar to the Khayo, Nyala-West, Saamia, and Songa dialects to its southwest (Marlo 2007, 2008, to appear). These dialects have predictable tone systems, which lack lexical tonal contrasts in verb roots (Odden 1989). Stem tone patterns generally reflect the presence of grammatical $\mathrm{H}$ tones called "melodic Hs", which mark tense-aspect-mood-polarity distinctions and surface on different positions of the stem depending on the 'tense', used here as a cover term for all TAMP distinctions. Complex tonal alternations are triggered in Tura by $\mathrm{H}$-toned prefixes, including object prefixes, the reflexive prefix, and some tense prefixes. This paper systematically discusses each of the known melodic tonal patterns in Tura as well as other tonal alternations and discusses variation between two speakers of the dialect.

Like many other Bantu languages (Hyman 2001, Stevick 1969), Tura has a privative tonal system with an underlying $\mathrm{H}$ vs. $\varnothing$ opposition. There is a surface contrast between level $\mathrm{H}$ and level $\mathrm{L}$ on short and long vowels, where $\mathrm{L}$ is the default tone, i.e., the automatic phonetic implementation of phonological $\varnothing$. There is no clear evidence for phonologically specified L tone in Tura, although as discussed in section 3.1, L could possibly be involved in the account of downstep in the dialect. Falling and rising tones are found on long vowels as combinations of $\mathrm{H}$ and $\varnothing$, though one speaker, Wabala, systematically eliminates potential $\varnothing \mathrm{H}$ 
rising tones (see section 8.2). Phrase-final $\mathrm{H}$ tones are realized with some variation as phonetically falling, a predictable effect of phonetic implementation that is not reflected in the transcriptions below.

Like other western and central Luyia dialects, all tenses of Tura are inflected with a melodic $\mathrm{H}$, and as is typical within Luyia, Tura has an unusually high number of tonal melodies. Abstracting away from differences due to to the prosodic shape of the verb stem, there are nine known surface patterns, whose differences derive from a small set of parameters. These melodic patterns are summarized in (2) for verb stems of three or more syllables with a long stem-initial syllable, along with melody-internal forms with the $3 \mathrm{sg}$ object prefix (OP) /mú-/ and the reflexive prefix $\left(\mathrm{OP}_{\mathrm{Refl}}\right) / \mathrm{e}^{\mathrm{H}}-/$.

(2) Tonal marking of tense-aspect-mood-polarity distinctions in Tura ${ }^{2}$

Pattern la: Indefinite Future

ßa-li[teex-ér-án-á]

a-li-mú[liingéér-á]

a-ly-ee[kaangúlúl-á] 'they will cook for e.o.'

'he will watch him' +OP

'he will untie himself'

Pattern 1b: Near Future

a-lá[fuundúlúx-á]

a-lá-mu[liingéér-á]

a-l-ée[kaangúlúl-á]

'he will unknot'

'he will watch him'

$+\mathrm{OP}$

'he will untie himself'

$+\mathrm{OP}_{\text {Refl }}$

Pattern 2a: Indefinite Future Negative

sí-ßa-li[liingéér-a] tá

'they will not watch'

ś1-ßa-li-mú[liingéér-a] tá

'they will not watch him'

$+\mathrm{OP}$

ś1-y-ee[ [ßoolól-aang-a] $]^{3}$

'he is not untying himself'

$+\mathrm{OP}_{\text {Refl }}$

Pattern 2b: Immediate Past Negative

sí- $\beta$-a-xá[teex-án-ir-a] tá

'they did not just cook for e.o.'

ś1-y-a-xá-mu[liingéér-a] tá

'he did not just watch him'

$+\mathrm{OP}$

ś-y-a-x-ée[liingéér-a] tá

'he did not just watch himself'

$+\mathrm{OP}_{\text {Refl }}$

\footnotetext{
${ }^{2}$ These examples have the 3 sg and $3 \mathrm{pl}$ subject prefixes $a$ - and $\beta a-$, which are both toneless and do not trigger tonal alternations.

${ }^{3}$ This example is from the Present, another tense with Pattern 2a tonal properties. Reflexive forms in the Indefinite Future Negative have not been elicited.
} 
Pattern 3a: Hodiernal Perfective
a[fuunduluul-é]
'he unknotted'
a-ßá[ríingeer-eré]
'he watched them'
$+\mathrm{OP}$
y-ee[káánguluul-é]
'he untied himself'
$+\mathrm{OP}_{\text {Refl }}$

Pattern 3b: Imperativesg

[liingeer-á]

mu[língeer-é]

w-e[káángulul-é]

'watch!'

'watch him!'

$+\mathrm{OP}$

'untie yourself!'

$+\mathrm{OP}_{\text {Refl }}$

Pattern 4a: Remote Past

$\beta$-aá[téex-an-ir-a]

'they cooked for e.o.'

$y$-á-mu[língeer-a]

y-ée[tééx-er-a]

'he watched him'

$+\mathrm{OP}$

'he cooked for himself'

$+\mathrm{OP}_{\text {Refl }}$

Pattern 4b: Subjunctive

xu[teex-án-ir-e]

'let's cook for e.o.'

xu-mú[káangulul-e]

'let's untie him'

$+\mathrm{OP}$

xw-ee[káángulul-e]

'let's untie ourselves'

$+\mathrm{OP}_{\text {Refl }}$

\section{Pattern 4c: Imperative Sg Negative}

o-la[liingeer-a] tá

o-la-mú[kaangúlul-a] tá

o-l-ee[língeer-a] tá 'don't watch!'

'don't untie him!'

'don't watch yourself!'
$+\mathrm{OP}$

$+\mathrm{OP}_{\text {Refl }}$

The melodies are given numeric and alphabetic labels, e.g., Pattern 1a. Each numeric value reflects a major difference in the surface position or in some other tonal property of the melodic $\mathrm{H}$. Patterns $1-3$ are defined primarily by the position of the melodic $\mathrm{H}$ : on the moras after the stem-initial syllable (Pattern 1), on the moras of the second stem syllable (Pattern 2), on the stem-final mora (Pattern 3). The Pattern 4 melodic Hs are found on the moras of the first (Pattern 4a) or second syllable of the stem (Patterns $4 \mathrm{~b}-\mathrm{c}$ ); what unifies these melodies into a single Pattern is the interactions of their melodic Hs with $\mathrm{H}$-toned prefixes: the Pattern 4 melodic Hs do not surface in combination with the $\mathrm{H}$ of the reflexive, which surfaces on the moras of the stem-initial syllable.

Alphabetic distinctions reflect relatively minor tonal differences. The "a" and "b" subtypes reflect differences in the underlying tone of the tense prefix in Patterns 1-2: "a" melodies have a toneless tense prefix, while " $b$ " melodies have 
a H-toned tense prefix. The differences in alphabetic labels in Patterns 3-4 reflect more or less "quirky" tonal differences. Pattern 3a differs from Pattern $3 b$ in that the $\mathrm{H}$ of an object prefix spreads to the stem-initial mora in Pattern $3 \mathrm{a}$, while it shifts to the stem-initial syllable in Pattern 3b. The Pattern 4 subtypes differ in whether the melodic $\mathrm{H}$ surfaces on moras of the first (Pattern 4a) or second (Patterns 4b-c) stem syllable and the nature of the interaction of the melodic $\mathrm{H}$ with H-toned prefixes: the Pattern 4a-b melodic Hs do not surface after a H-toned prefix, the Pattern $4 \mathrm{c}$ melodic $\mathrm{H}$ surfaces only after a H-toned prefix.

This taxonomy partially reflects the robustness of the melody within the Tura TAMP system. A list of tenses in which each of these melodies is found is provided in (3). ${ }^{4}$ Pattern 1 occurs in the largest number of tenses and includes the tenses that have the 'lexical' tonal pattern lacking a melodic $\mathrm{H}$ in conservative Luyia dialects like Tachoni (Odden 2009). Pattern 2 is also common, while the Pattern 3 and Pattern 4 a melodies occur in only one or two tenses each. This robustness measure is not perfect, however, as the Pattern $4 \mathrm{~b}$ and Pattern $4 \mathrm{c}$ melodies occur in at least three tenses each.

Summary of tenses in each melody

Pattern la

Hesternal Perfective

Indefinite Future

Present

Pattern $1 b$

Immediate Past

Near Future

Near Future Negative

Remote Future

Remote Future Neg. y-aa[kaangúlúúl-é]

ßa-li[teex-ér-án-á]

a[teex-ááng-á] 'he untied'

'they will cook for e.o.'

'he is cooking'

${ }^{4}$ This list includes the known contexts in which each melody occurs for which complete data have been collected and are reported in this article in the main text or appendix. There are undoubtedly other verbal contexts in the language that take these and possibly other melodic patterns. One unstudied context that likely complicates but possibly helps better understand the "natural class" of features or properties underlying each Pattern is relative clauses. In Khayo, relativization plays a role similar to negation in determining the melody for different tenses (Marlo 2009). Based on parallel data in Khayo and Marachi (Marlo 2007, 2009), there is also likely to be a currently unattested Pattern 5 melody in Tura found in certain conditional clauses, where the entire verb, including prefixes, surfaces toneless. 


\section{Pattern $2 a$}

Hest. Perf. Neg. $[W]^{5} \quad$ sí-y-aa[liingéer-ere] tá 'he did not watch'

Indefinite Future Neg. sí- $\beta$ a-li[liingéér-a] tá 'they will not watch'

Present Negative sí- $\beta$ a[fuundix-a] tá 'they are not knotting'

\section{Pattern $2 b$}

Immediate Past Neg. sí- $\beta$-a-xá[teex-án-ir-a] tá 'they did not just cook for e.o.'

Pattern $3 a$

Hodiernal Perfective a[funduluul-é] 'he unknotted'

Pattern $3 b$

Imperative $_{S g}$

[liingeer-á]

'watch!'

\section{Pattern $4 a$}

Remote Past

$\beta$-aá[téex-an-ir-a]

Remote Past Negative sí-y-á[fuundix-a] tá

'they cooked for e.o.' 'he did not knot'

\section{Pattern $4 b$}

Crastinal Future

Imperative $\mathrm{Pl}$

Subjunctive

n-aa[liingáál-e]
mu[saambúl-e]
xu[teex-án-ir-e] 'he will watch'

'you (pl) de-roof!'

'let's cook for e.o.'

\section{Pattern $4 c$}

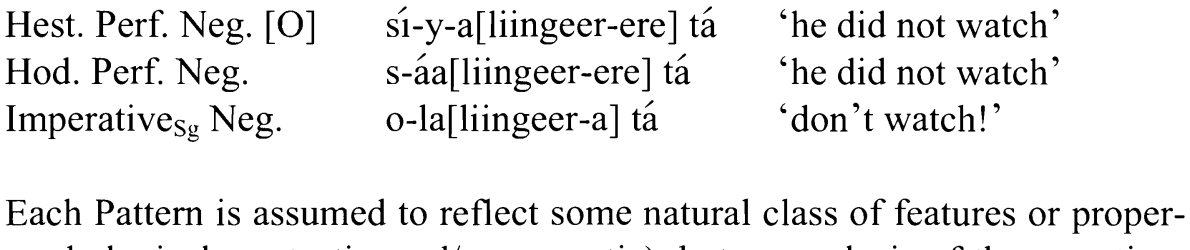
ties (morphological, syntactic, and/or semantic), but an analysis of these particu-

\footnotetext{
Most examples provided here and below reflect the tonal patterns of both speakers, but some examples are representative of only one of the speakers. Examples attested by Okumu only are indicated by [O], and examples attested by Wabala only are indicated by [W]. Examples with no explicit marking of the source are attested by both speakers, except where otherwise noted in the text. In some cases, examples are attested by only one of the speakers because identical examples were not collected from both speakers. In other cases, examples are attested by only one of the speakers because the examples were produced differently by the speakers. See section 8 for discussion of the variation between the two speakers.
} 
lar groupings of tenses into Patterns is not currently possible. Polarity partly defines the set of Pattern 2 and Pattern 4c contexts, but polarity differences do not affect the set of Pattern $1 \mathrm{~b}$ and Pattern $4 \mathrm{a}$ tenses. Similarly, the Pattern $4 \mathrm{~b}$ contexts all take the final vowel suffix $-e$, but not all tenses with $-e$ are in Pattern $4 \mathrm{~b}$, e.g., the Pattern 1b Remote Future. Several of the tonal rules posited below are restricted such that apply only in certain Patterns but not others. For the present purposes, each Pattern refers to the listed set of tenses in (3), with the expectation that that this listed set of tenses can be replaced in the future by some features or properties, once they are better understood.

This classification of the tonal melodies into various Patterns is meant to facilitate cross-Luyia comparison and ultimately the reconstruction of the ProtoLuyia melodic tonal system. Khayo has a very similar grouping of tenses into melodic patterns with similar tonal properties (Marlo, to appear). For example, the Hesternal Perfective, Indefinite Future, and Present tenses also function together as the Pattern la melody in Khayo and have a melodic $\mathrm{H}$ that surfaces from the second syllable of the stem to the final. This classification system allows for differences to be identified in the groups of tenses that take a particular melody and in the specific tonal properties of the melodies. For example, the tenses that are classified as Pattern $1 \mathrm{~b}$ in Tura subdivide into two distinct subtypes (Patterns $1 \mathrm{~b}$ vs. 1c) in Khayo, differing in the tonal properties of short verb stems. Additionally, the melodic distinction between Patterns $2 \mathrm{a}$ and $4 \mathrm{c}$ in Tura is neutralized into a single Pattern 2a melody in Khayo. It remains to be seen how well this classification system works for more distantly related Luyia dialects or for other Bantu languages outside Luyia.

Several important observations concerning the main similarities and differences of the Tura tonal melodies are given in (4). These melodies differ in their surface position on the stem (4a), whether the tense prefix is $\varnothing$ or $H(4 b)$, and how the melodic $\mathrm{H}$ interacts with $\mathrm{H}$-toned prefixes (4c-f).

(4) Summary of the tonal differences among the Tura melodies

a. The surface position of the melodic H (in trisyllabic and longer stems)

i. on the moras after the stem-initial syllable: Pattern 1

ii. on the moras of the second stem syllable only: Patterns 2, 4b, 4c

iii. on the stem-final mora only: Pattern 3

iv. on the moras of the stem-initial syllable only: Pattern $4 \mathrm{a}$ 
b. The tone of the tense prefix

i. H tense prefix: Patterns $1 b, 2 b$, and $4 a$.

ii. $\varnothing$ tense prefix: Patterns 1a, 2a, 3a-b, 4b-c.

c. Whether and how a melodic $H(M H)$ surfaces after a $H$-toned prefix

i. MH surfaces whether or not there is a H-toned prefix: Patterns 1-3.

ii. MH does not surface after a H-toned prefix: Patterns 4a-b.

iii. $\mathrm{MH}$ surfaces only after a H-toned prefix: Pattern $4 \mathrm{c}$.

d. Whether a melodic $H$ is realized on a monosyllabic stem after $H$

i. Yes: Pattern 1.

ii. No: Patterns 2, 4c.

e. Whether the H of a prefix doubles onto the stem-initial mora

i. Doubling applies: when the melodic $\mathrm{H}$ does not surface (Pattern $4 \mathrm{a}$ no object prefix, Pattern $4 \mathrm{~b}$ with object prefix), when the melodic $\mathrm{H}$ surfaces only on the stem-final mora (Pattern 3a with object prefix).

ii. Doubling does not apply: all other contexts (the melodic $\mathrm{H}$ surfaces on the moras of the first or second syllable of the stem).

f. How the $H$ of the reflexive interacts with the melodic $H$

i. The reflexive $\mathrm{H}$ does not surface; the melodic $\mathrm{H}$ does: Patterns 1-2.

ii. The reflexive $\mathrm{H}$ surfaces; the melodic $\mathrm{H}$ does not: Pattern 4.

iii. The reflexive $\mathrm{H}$ and the melodic $\mathrm{H}$ surface: Pattern 3.

The general approach taken here to account for these many differences among the Tura tonal melodies is to posit several distinct Pattern-specific rules of Melodic H Assignment (MHA)-the rule that initially maps the melodic $\mathrm{H}$ to the verb stem. These rules, along with one additional Pattern-specific rule that shifts the melodic $\mathrm{H}$ from the position to which it is assigned to the moras of the following syllable, account for the different surface positions of the melodic Hs in (4a). Some MHA rules are sensitive to the presence or absence of $\mathrm{H}$ tone before the target mora, which accounts for the differences in $(4 \mathrm{c})$. The other interactions between the melodic $\mathrm{H}$ and prefixes in $(4 \mathrm{~d}-\mathrm{f})$ derive from the relative ordering of the MHA rules with respect to Doubling, a rule assigning the reflexive $H$ to the stem (Object $\mathrm{H}$ Assignment), and a rule that deletes $\mathrm{H}$ from a monosyllabic stem after $\mathrm{H}(\mathrm{H}[\mathrm{H}]$ Deletion). 
In the following sections, each of the melodic tone patterns is discussed, along with tonal alternations triggered by prosodic differences in the verb stem and by object prefixes and the reflexive prefix. A summary and discussion of aspects of the analysis are provided in section 7. Variation between the two Tura speakers is discussed in section 8 , concluding remarks are offered in section 9, and an appendix containing additional data from other tenses is provided in section 10 .

\section{Pattern 1.}

Pattern 1 has a melodic $\mathrm{H}$ suffix that links to the stem-final mora and spreads left. There are two Pattern 1 subtypes: Pattern 1a, which has a toneless tense prefix, and Pattern 1b, which has a H-toned tense prefix.

3.1 Pattern 1a. Pattern la is found in the tenses in (5). This section discusses the Indefinite Future; data for the other tenses are provided in section 10.1 in the appendix.

\section{Pattern la tenses}

Hesternal Perfective Indefinite Future

Present

The Pattern la melodic $\mathrm{H}$ is realized on the lone mora of monosyllabic verb stems (6a), on all moras of disyllabic stems (6b), and on all moras after the initial syllable of trisyllabic and longer stems $(6 \mathrm{c})$.

(6) Indefinite Future 'he (a-) / they ( $\beta \mathrm{a}-)$ will ...'
a. a-li[fw-á]
'die'
a-li[ry-á]
'eat'
b. a-li[ßék-á]
'shave'
a-li[xín-á]
'dance'
a-li[réé $\beta$-á]
'ask'
a-li[tééx-á]
'cook'
c. a-li[ßakál-á]
'set out to dry' a-li[ßukúl-á]
'take'
ßa-li[karááng-á] 'fry'
a-li[lexúúl-á]
'release'
a-li[fuundix-á] 'knot'
ßa-li[siindıx-á]
'push'
a-li[liingéér-á]
'watch'
ßa-li[saangáál-á]
'be happy'
ßa-li[siindı́x-án-á] 'push e.o.'
ßa-li[teex-ér-án-á]
'cook for e.o.' 
The combination of a $\mathrm{V}$-initial stem with a $\mathrm{V}$-final prefix gives rise to vowel hiatus. Hiatus is resolved in Tura by a number of relatively common repair strategies, such as the formation of glides from high vowels plus compensatory lengthening. The processes resolving hiatus create potential contour tones when one of the input moras has or acquires a $\mathrm{H}$. The underlying moraic structure of the $/ \mathrm{V}+\mathrm{V} /$ combination is generally preserved as a long vowel on the surface, along with the tonal pattern that otherwise occurs on those moras: $\varnothing+\varnothing \rightarrow \varnothing \varnothing, \mathrm{H}+\varnothing$ $\rightarrow \mathrm{HØ}, \varnothing+\mathrm{H} \rightarrow \varnothing \mathrm{H}, \mathrm{H}+\mathrm{H} \rightarrow \mathrm{HH}$.

The tonal patterns of V-initial stems in Pattern 1a are essentially the same as $\mathrm{C}$-initial stems. VCV stems in (7a) surface with a $\mathrm{H}$ on both moras of the stem, and longer stems ( $7 \mathrm{~b}$ ) surface with a $\mathrm{H}$ on all moras after the stem-initial syllable. A rising tone is created as the combination of $\varnothing+\mathrm{H}$ through resyllabification in $\mathrm{VCV}$ stems, under the assumption that tones remain linked to their moras throughout the processes of hiatus resolution. The data from VCV stems in (7a) are those of Okumu; we see in section 8.2 that the other Tura speaker, Wabala, predictably eliminates this and other rising tones.

Indefinite Future V-initial stems 'he will ...'
a. a-l[ímb-á] [O] 'sing'
a-1[ínts-á] [O]
'come'
b. a-1[iirúx-á]
'run'
a-ly[aaníx-á]
'set out to dry'
a-ly[aand'́́k-á] 'write'
a-ly[aasyáák-á]
'split wood'

All known object prefixes are $\mathrm{H}$ in Tura. ${ }^{6}$ The object prefix surfaces $\mathrm{H}$ in Pattern 1a, and the stem tone pattern is unaffected: $\mathrm{H}$ on the lone mora of monosyllabic stems (8a), on all moras of disyllabic stems (8b), and on all moras after the initial syllable of trisyllabic and longer stems $(8 \mathrm{c})$.

\footnotetext{
${ }^{6}$ Due to time constraints, only the object prefixes most likely to have any tonal difference, based on comparative studies of other Luyia dialects, were elicited: $3 \operatorname{sg} m u^{-}, 1 \operatorname{sg} N_{-}^{-}$, and reflexive $e^{{ }^{H}}$; $3 \mathrm{pl} \beta a^{\prime}$ - was also occasionally elicited and, as expected, shows the same tonal properties as the $3 \mathrm{sg}$ and $1 \mathrm{sg}$ object prefixes. Combinations of two object prefixes were judged ungrammatical by Okumu. Wabala pronounced combinations of the $3 \mathrm{sg}$ and the $1 \mathrm{sg}$ object prefixes, which are possible in Khayo (Marlo 2009, see section 8), in Pattern 1a on one occasion, but these forms were not discussed again.
} 
Indefinite Future + $O P$ ' he will ... him'
a. a-li-mú[ry-á]
'fear'
a-li-mú[xw-á]
'pay dowry"
$\begin{array}{ll}\text { b. a-li-mú[ßék-á] } & \text { 'shave' } \\ \text { a-li-mú[l'índ-á] } & \text { 'wait for' }\end{array}$
a-li-mú[rém-á]
'chop'
a-li-mú[rééß-á]
'ask'
c. a-li-mú[ßukúl-á] 'take'
a-li-mú[xalák-á]
'cut'
a-li-mú[lexúúl-á] 'release'
a-li-mú[ßßoolól-á]
'untie'
a-li-mú[teex-ér-á] 'cook for'
a-li-mú[liingéér-á]
'watch'

Note that the $\mathrm{H}$ of the object prefix and the melodic $\mathrm{H}$ are realized at the same pitch level in monosyllabic and disyllabic stems (8a-b). Although it is not directly indicated in the transcriptions, Tura has automatic downstep of Hs separated by $\varnothing$, so the melodic $H$ is realized at a lower pitch level than the $H$ of the object prefix in trisyllabic and longer stems (8c), but each mora of the melodic $\mathrm{H}$ on the stem is realized at the same pitch level. Hs that become adjacent during the course of the derivation are sometimes realized at the same pitch level, as in (8ab), but in one known context-Pattern 3 b forms with an object prefix-a H-toned prefix surfaces on the stem-initial mora immediately followed by a downstepped melodic $\mathrm{H}$ on the stem-final mora, e.g., $m u[\beta e ́$ 'ké] 'shave him!'.

Note further that the $\mathrm{H}$ of the object prefix does not spread onto the steminitial mora in trisyllabic and longer stems $(8 \mathrm{c})$. The $\mathrm{H}$ of a prefix spreads to the stem-initial mora in some other contexts where the melodic $\mathrm{H}$ does not surface at the left edge of the stem, e.g., Pattern $3 \mathrm{a} a$ - $\beta a$ [líingeer-eré] 'he watched them', cf. a[fuunduluul-é] 'he unknotted'.

The data in (9) have the $1 \mathrm{sg}$ object prefix $N$-, a homorganic nasal that triggers a variety of $\mathrm{NC}$ effects common to Bantu languages (see Hyman 2003 for an overview). Here we find the usual stem tone patterns: all stem moras surface $\mathrm{H}$ in monosyllabic and disyllabic stems, and all moras after the stem-initial syllable surface $\mathrm{H}$ in trisyllabic and longer stems. The nasal prefix lengthens the preceding

7 The appropriate gloss for this form is 'he will pay her dowry' or 'he will pay the dowry for her', not to be confused with the (unattested but predicted) form $a$-li-mú $[x w$-éér-á] 'he will pay the dowry for him', with the applicative suffix.

${ }^{8}$ Downstep is also transcribed in Pattern 4b Remote Past Negative forms in (86) with V-initial stems and an object prefix such as sí-y-á'-mw[ïr-a] tá 'he did not kill him', which is also attested as sí-y-á-mw[ïr-a] tá, with a stem-initial rise. As noted in the discussion of these forms below, this is likely a coarticulatory phonetic effect in the implementation of a rise after $\mathrm{H}$. Downstep is therefore 'automatic', since the Hs are separated phonologically by $\varnothing$. 
vowel (even when the nasal is deleted). The nasal itself is not tone-bearing, and the $\mathrm{H}$ of the object prefix remains associated to the mora of the nasal, which goes to the left, surfacing as a $Ø \mathrm{H}$ rise on the lengthened pre-NC vowel, cf. Kerewe, where the $\mathrm{H}$ of the nasal prefix shifts to the right, while the nasal's mora goes to the left (Odden 2000).

\begin{tabular}{|c|c|c|c|}
\hline a-lí1[ry-á] & 'fear' & a-líı[mbék-á] & 'shave' \\
\hline a-líı[nźrr-á] & 'kill' & a-lí1[núı́nd-á] & 'wait for' \\
\hline a-liı́[ndéé $\beta$-á] & 'ask' & a-lí́[mbukúl-á] & 'take' \\
\hline a-lí1[nyimb-ír-á] & 'sing for' & a-líi[mboolól-á] & 'untie' \\
\hline a-lír[nzasyáák-irr-á] & 'split for' & a-líi[ndexúúl-á] & 'release' \\
\hline a-lí1[niingéér-á] & 'watch' & a-lí1mbodóóxán-á] & 'go around' \\
\hline
\end{tabular}

When the 3 sg object prefix mú- co-occurs with a V-initial stem, the high vowel of the object prefix becomes a glide, and the stem-initial vowel is lengthened, preserving the underlying mora of the prefix vowel. The $\mathrm{H}$ of the object prefix remains associated to its underlying mora, which goes to the right, creating a $\mathrm{H} \varnothing$ falling tone through resyllabification with the stem-initial vowel, and the melodic $\mathrm{H}$ surfaces on all moras after the stem-initial syllable. The tonal pattern of VCV stems in (10a) is somewhat unexpected since C-initial disyllabic stems surface with a $\mathrm{H}$ on the stem-initial mora. One might have expected a level $\mathrm{H}$

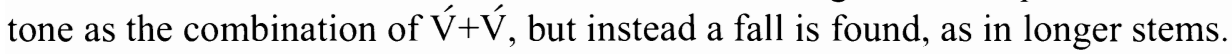

(10) Indefinite Future + $O P$ V-initial stems 'he will ... him'

a. a-li-mw[áar-á] 'operate on' a-li-mw[1ir-á] 'kill'

b. a-li-mw[1imb-ír-á] 'sing for' a-li-mw[1ixás-y-á] 'help sit' a-li-mw[áandík-1́r-á] 'write for' a-li-mw[áasyáák-1r-á] 'split for'

Like other object prefixes, the reflexive contributes an underlying $H$, but it has different tonal properties from other object prefixes. The $\mathrm{H}$ of the reflexive never surfaces on the reflexive itself. The reflexive $H$ surfaces on the moras of the stem-initial syllable in Patterns 3-4, e.g., Pattern 3a y-ee[káánguluul-é] 'he untied himself', cf. a[fuunduluul-é] 'he unknotted'. However, the H of the reflexive does not always surface; it systematically fails to be realized in Patterns 1-2; only the melodic $\mathrm{H}$ is realized on the stem. The monosyllabic stem in (11a) and the disyllabic stems in (11b) realize the Pattern 1a melodic $\mathrm{H}$ on all stem moras, while the 
longer stems in $(11 \mathrm{c})$ realize the melodic $\mathrm{H}$ on all moras after the stem-initial syllable.

(11) Indefinite Future $+O P_{\text {Refl }}[\mathrm{O}]$ 'he will ... himself'
a-ly-ee[ry-á]
'fear'
a-ly-ee[ßék-á]
'shave'
a-ly-ee[y-ir-á]
'kill'
a-ly-ee[fwáál-á]
'dress'
a-ly-ee[fwíimb-á] 'cover'
a-ly-ee[fumír-á]
'stab'
a-ly-ee[y-imb-ir-á] 'sing for'
a-ly-ee[ßoolól-á]
'untie'
a-ly-ee[fwiimbúl-á] 'uncover'
a-ly-ee[karáang-ir-á] 'fry for'
a-ly-ee[y-asyáák-ir-á] 'split for'
a-ly-ee[kaangúlúl-á] 'untie'

The main tonal properties of Pattern 1 can be accounted for by the rules in (12). The melodic $\mathrm{H}$ is first assigned to the stem-final mora by Melodic H Assignment (MHA): Final, a rule that applies only in Pattern 1 contexts. The leftward extent of the melodic $\mathrm{H}$ is determined by two spreading rules: Minimal Spread, which spreads $\mathrm{H}$ to all moras of a preceding syllable within the stem, and Unbounded Spread, which spreads $H$ iteratively leftward within the stem but not onto a mora of the stem-initial syllable.

(12) MHA: Final

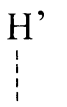

$\mu]_{\text {stem }}$

(Pattern 1)

(Iterative,

$\mu \mu \mu$ domain: stem)

Unbounded Spread

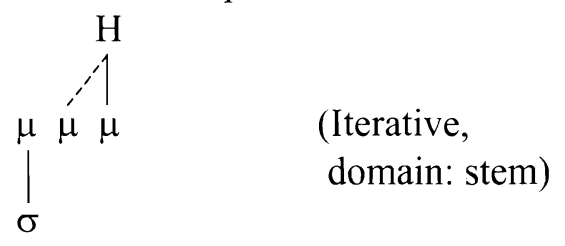

Minimal Spread

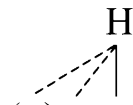

( $\mu) \mu \mu$

(Domain: stem)

In monosyllabic stems (13a), the melodic $H$ is assigned to the stem-final mora, but Minimal Spread does not subsequently apply because the mora to the left of the melodic $\mathrm{H}$ is not within the stem. In disyllabic stems (13b-c), the melodic $\mathrm{H}$ is assigned to the stem-final mora and spreads to all moras of the steminitial syllable by Minimal Spread. In trisyllabic and longer stems (13d), the melodic $\mathrm{H}$ is assigned to the final, spreads to the moras of the preceding syllable by 
Minimal Spread, and then continues to spread leftward up to but not onto the moras of the stem-initial syllable by Unbounded Spread.

(13) Pattern Ia

a. Monosyllabic stems: a-li[fw-á] 'he will die'

$\begin{array}{ccc}\text { MHA: Final } & \text { Minimal Spread } & \text { Unbounded Spread } \\ \vdots & & \\ \text { a-li[fw-a }] & \rightarrow & \text { Does Not Apply } \rightarrow \text { Does Not Apply }\end{array}$

b. CVCV stems: a-li[ßék-á] 'he will shave'

MHA: Final Minimal Spread Unbounded Spread

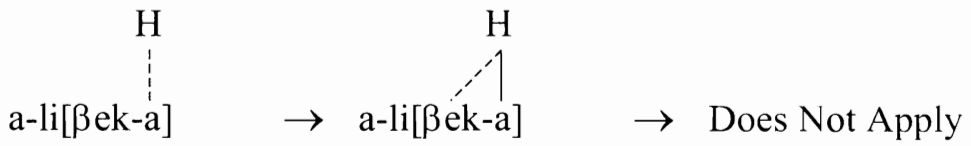

c. CVVCV stems: a-li[tééx-á] 'he will cook'

MHA: Final Minimal Spread Unbounded Spread

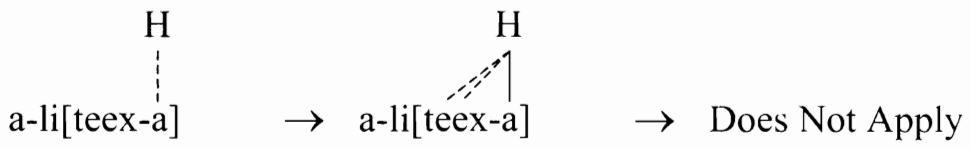

d. Trisyllabic and longer stems: ßa-li[teex-ér-án-á] 'they will cook f. e.o.' MHA: Final Minimal Spread Unbounded Spread

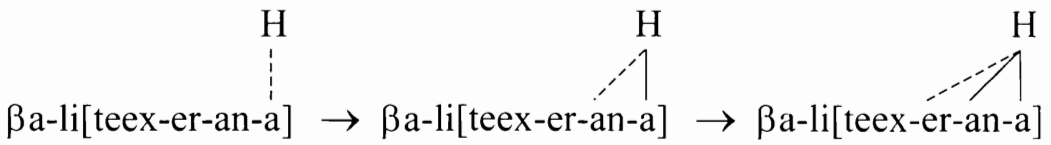

The formulations of the tonal rules in (12) and the derivations in (13c-d) highlight an important issue that arises in Tura tone and throughout Luyia tonal systems-the status of the tone-bearing unit (TBU): whether tones link to moras or syllables, and how to formulate tonal generalizations in the language which sometimes have contradictory patterns of sensitivity to syllable-internal vowel length differences. Two facts of Tura tone require the mora to the TBU. First, there is a surface contrast between level $\mathrm{H}$, rise, and fall on long vowels, and these contour tones are best analyzed as $\varnothing \mathrm{H}$ and $\mathrm{H} \varnothing$ sequences. Second, forms like the Pattern 3a a- $\beta a$ [língeer-eré] 'he watched them', which has a H-toned object prefix and a melodic $\mathrm{H}$ which surfaces on the stem-final syllable, motivate 
a rule of Doubling that spreads the $\mathrm{H}$ of a prefix a single mora to the right to the stem-initial mora, cf. a[fuunduluul-é] 'he unknotted'. This rule cannot be stated if syllable-internal moraic structure is invisible to tonal rules.

Although the mora is unquestionably the TBU in Tura, many tonal generalizations in the language are insensitive to syllable weight differences and require reference to the syllable in their formal account. For example, whether the stem-initial syllable is short or long, Unbounded Spread does not spread the melodic $\mathrm{H}$ onto the moras of the stem-initial syllable. Furthermore, various rules discussed below assign a melodic $\mathrm{H}$ to all moras of the stem-initial syllable, whether this syllable is short or long. These syllable-level generalizations are formalized in the present analysis using parentheses notation at the moraic level.

It is logically possible that the initial syllable of disyllabic stems surfaces as a level $\mathrm{H}$ as the combined result of two rules: a rule of Minimal Spread that spreads $\mathrm{H}$ by only a single mora left, followed by a rule that eliminates the intermediate rising tone in the stem-initial syllable by syllable-internal spreading: ali[teex-á] $\rightarrow$ a-li[teéx-á] $\rightarrow$ a-li[tééx-á] 'he will cook'. This solution fails because there is no general restriction against rising tones in Okumu's idiolect; rising tones are commonly created and preserved in V-initial stems, e.g., $a$-l[iits-á] 'he will come' (see (14) below). Similar reasoning precludes a purely moraic statement of Unbounded Spread and the rules discussed below that assign $\mathrm{H}$ to all moras of the stem-initial syllable. It is logically possible to divide stem-initial H assignment into two steps: assignment of $\mathrm{H}$ to the stem-initial mora, followed by leveling of fall when the stem-initial syllable is long, but this two-step solution is rejected for similar reasons as the two-step solution to leftward spreading: there is no restriction on falling tones, which commonly arise through resyllabication of $\mathrm{H}+\varnothing$ and the application of the rule of Doubling.

Returning to the analysis of $\mathrm{V}$-initial stems, note that no additional rules are necessary to account for their tonal properties. The tonal pattern of VCV stems can be derived assuming cross-linguistically common tone and mora preserving principles. I assume that most tonal rules apply before rules resolving vowel hiatus and that there is an initial round of syllabification in which the steminitial mora is in a syllable distinct from the syllable of the preceding tense prefix $l i-$. As shown in the derivation in (14), which is simplified by omitting rules that do not apply such as Unbounded Spread and by showing the syllabic affiliation of 
vowels (moras) only, Minimal Spread associates the melodic $\mathrm{H}$ with the steminitial mora, and the various hiatus resolution rules then apply, creating a rise. ${ }^{9}$

(14) Pattern la, VCV stems: a-l[íits-á] [O] 'he will come'

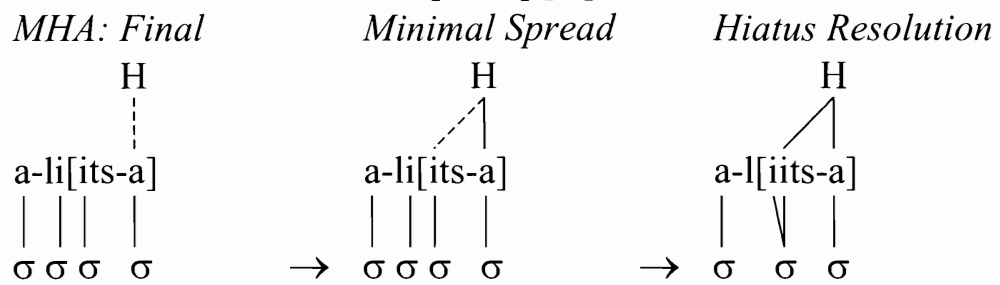

Turning now to Pattern la forms with an object prefix, we can note that the derivation of the stem tone patterns of these forms is straightforward, given the rules above, since the melodic $\mathrm{H}$ surfaces in the same positions as when there is no object prefix. However, several remarks remain to be made about these forms because they fail to show effects of some tonal rules found in other melodies discussed below. One of the most significant analytical challenges of the Tura tonal system is accounting for the many contexts where a rule motivated for one melody fails to apply in other melodies.

In the case of trisyllabic and longer stems with an object prefix such as $a-l i$ mú[liingéér-á] 'he will watch him', a rule of Doubling, which spreads $\mathrm{H}$ from a prefix immediately preceding the stem to the stem-initial mora, does not apply. Doubling, whose formulation is provided in (15), applies in forms like Pattern 3a a-ßá[líingeer-eré] 'he watched them', cf. a[fuunduluul-é] 'he unknotted'. Doubling does not apply in Pattern 1 because it is ordered after Pattern 1 MHA and requires the moras of the first two syllables of the stem to be toneless.

9 Since the product of Hiatus Resolution at the stem boundary is always a long monophthong, the stem boundary is shown to include the mora of the preceding prefix vowel in V-initial stems to avoid the appearance of a syllable boundary if the "underlying" position of the stem boundary were shown, e.g., a-li[ítsá] 'he will come'. There is no evidence that the stem boundary actually moves as a consequence of the rules of Hiatus Resolution. 
(15) Doubling

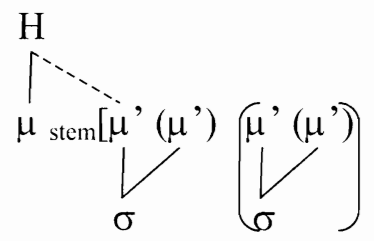

The derivation of monosyllabic stems with an object prefix in Pattern la such as a-li-mú[ry-á] 'he will fear him' should be apparent-the melodic $\mathrm{H}$ is assigned to the stem-final mora, following the $\mathrm{H}$ of the object prefix. However, structurally similar forms undergo alternations in other melodies, so we must account for the lack of alternations here. The examples in (16) show that the only context in which a melodic $\mathrm{H}$ is realized on a monosyllabic stem after a $\mathrm{H}$-toned prefix is Pattern 1-in Pattern 1a forms with an object prefix and, as we will see in detail below, in Pattern $1 \mathrm{~b}$ forms, which have a $\mathrm{H}$-toned tense prefix.

(16) Melodic $H$ is realized on a monosyllabic stem after a H-toned prefix

Pattern la + OP (Indefinite Future, 'he will ... him')

a-li-mú[ry-á] 'fear'

Pattern Ib (Near Future, 'he will ...')

a-lá[fw-á] 'die'

The examples in (17) show that in Pattern 2 and Pattern 4c, the melodic $\mathrm{H}$ is not realized on a monosyllabic stem following a $\mathrm{H}$-toned prefix. Other forms in the same context are provided to show that a melodic $\mathrm{H}$ is otherwise expected on the moras of the initial syllable of monosyllabic and disyllabic stems. (In Patterns 3, $4 \mathrm{a}$, and $4 \mathrm{~b}$, the relevant context cannot be created.)

(17) Melodic $H$ is not realized on a monosyllabic stem after a H-toned prefix

Pattern $2 a+O P$ (Indefinite Future Negative, 'they will not ... him')

sí-ßa-li-mú[ry-a] tá 'fear' cf. s-áa-li[fw-á] tá [O] 'die'

Pattern $2 b$ (Immediate Past Negative, 'he did not just ...')

sí-y-a-xá[ly-a] tá 'eat' cf. sí-y-a-xá-mu[ry-á] tá [O] 'fear'

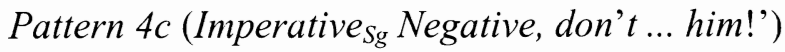

o-la-mú[ry-a] tá 'fear' cf. o-la-mú[rééß-a] tá 'ask' 
A rule called $\mathrm{H}[\mathrm{H}]$ Deletion, whose formulation is given in (18), is posited below to delete the melodic $\mathrm{H}$ from a monosyllabic stem after a $\mathrm{H}$-toned prefix. The interaction of the MHA rules with Doubling and the assignment of the $\mathrm{H}$ of the reflexive to the stem (discussed below) motivates an ordering in which Pattern 1 MHA precedes the Pattern 2 and Pattern 4c rules of MHA. H[H] Deletion must follow the Pattern 2 and Pattern 4c MHA, and by transitivity, Pattern 1 MHA. To prevent $\mathrm{H}[\mathrm{H}]$ Deletion from applying to the melodic $\mathrm{H}$ in Pattern 1, a rule of $\mathrm{Fu}$ sion specific to Pattern 1 is posited to fuse a melodic $\mathrm{H}$ on a monosyllabic stem with a preceding $\mathrm{H}$. Since there is only a single $\mathrm{H}$ after Fusion applies, H[H] Deletion subsequently fails to apply in Pattern 1 forms.
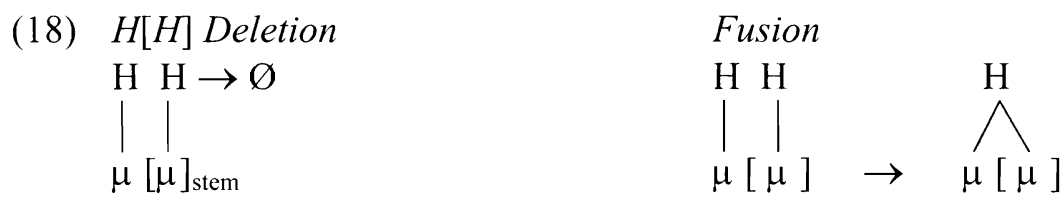

(Pattern 1)

Before continuing with the analysis of $\mathrm{V}$-initial stems with an object prefix, we now consider the tonal representations of forms with short verb stems and an object prefix, in which the $\mathrm{H}$ of the object prefix and the melodic $\mathrm{H}$ on the steminitial mora are realized at the same pitch level. To understand these forms, we must compare the range of cases where adjacent $\mathrm{Hs}$ are realized at the same pitch level with those where the second $\mathrm{H}$ is downstepped. Recall that the second of two Hs separated by a toneless mora is automatically downstepped in Tura.

There is one known context in Tura with downstep: in Pattern $3 \mathrm{~b}$ forms with an object prefix such as $m u[\beta e ́$ 'ké] 'shave him!', cf. mu[líingeer-é] 'watch him!' (see also fn. 8). As we see below, the $\mathrm{H}$ of the object prefix is first assigned to all moras of the stem-initial syllable in these forms, and the melodic $\mathrm{H}$ is then assigned to the stem-final mora by MHA: Final II, a later rule of MHA.

There are many contexts in Tura where adjacent Hs are realized at the same pitch level. There is no downstep between H-toned prefixes and a stem-initial melodic H (19a), between the negative prefix sí- and the Remote Past tense prefix $a$ - in the Remote Past Negative (19b), and in all cases of a stem-final H immediately followed by the negative marker tá (19c). 
(19) Contexts where adjacent $H$ s are realized at the same pitch level

a. H-toned prefixes followed by the melodic $H$

Pattern la + OP (Indefinite Future, 'he will ... him')

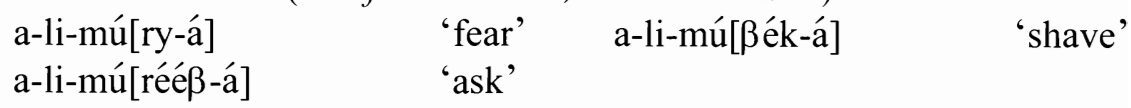

Pattern $1 b$ (Near Future, 'he will ...')

$\begin{array}{lll}\text { a-lá[fw-á] } & \text { 'die' } & \text { a-lá[ßék-á] } \\ \text { a-lá[tééx-á] } & \text { 'cook' } & \end{array}$

Pattern $2 a+O P$ (Indef. Fut. Neg., 'they will not ... him')

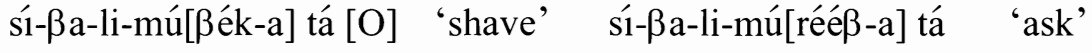

Pattern $2 b$ (Immediate Past Negative, 'he did not just ...')

sí-y-a-xá[ßék-a] tá [O] 'shave' sí-y-a-xá[rééß-a] tá 'ask'

Pattern $4 c+O P$ (Imperative $_{S g}$ Negative, 'don't ...!')

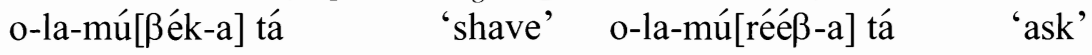

b. Negative marker sí-followed by the Remote Past tense prefix á-

Pattern 4 a (Remote Past Negative, 'he did not ...')

ś-y-á[teex-a] tá 'cook' sí-y-á[ßukul-a] tá 'take'

c. Stem-final melodic or reflexive H followed by the negative marker tá Pattern $1 b$ (Near Future Negative, 'he will not ...')

$\begin{array}{llll}\text { s-áa-lá[ly-á] tá } & \text { 'eat' } & \text { s-áa-lá[kón-á] tá } & \text { 'sleep' } \\ \text { s-áa-lá[línd-á] tá } & \text { 'wait' } & \text { s-áa-lá[Bukúl-á] tá } & \text { 'take' }\end{array}$

Pattern $2 a$ (Indef. Fut. Neg., 'he will not ...')

s-áa-li[fw-á] tá [O] 'die'

Pattern $2 b+O P$ (Immediate Past Negative, 'he did not just ... him') sí-y-a-xá-mu[ry-á] tá [O] 'fear' (but see fn. 16)

Pattern $4 a+O P$ (Remote Past Negative, 'he did not ... him')

sí-y-á-mu[ry-á] tá 'fear' 


$$
\begin{aligned}
& \text { Pattern } 4 c+O P_{\text {Refl }} \text { (Imperative }{ }_{S g} \text { Negative, 'don't ... yourself!') } \\
& \text { o-l-ee[ry-á] tá }
\end{aligned}
$$

Since there is a contrast between derived adjacent Hs separated by a downstep and derived adjacent $\mathrm{Hs}$ that are realized at the same pitch level, there must be a representational difference in the output of the phonology between these two patterns. There are two general approaches that could be used, which are schematized in (20).

(20) Representations of downstep

a. Every distinct H triggers downstep (Bickmore 2000, Odden 1982, Schuh 1998)

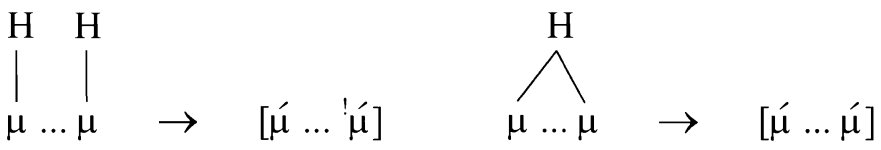

b. L triggers downstep (Bird 1966: 135, Clements \& Ford 1979: 206, Paster \& Kim 2007)

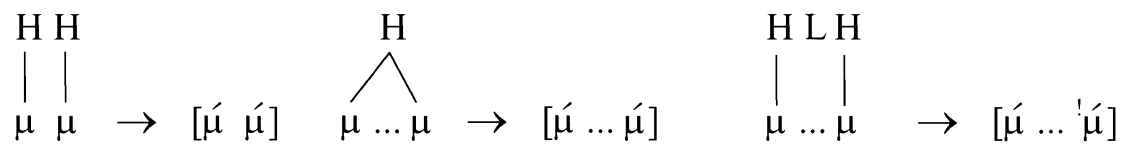

Capitalizing on the facts that (i) Tura has automatic downstep of the second of any two non-adjacent Hs, (ii) each link of a multiply linked $\mathrm{H}$ is realized at the same pitch level, and (iii) there is no other evidence in Tura for phonologically specified L tones, we could follow the approach of (20a), in which the second of any two Hs, whether adjacent or non-adjacent, is automatically lowered in pitch by the phonetics component. As a result, in any case where there are two input Hs that surface in adjacent positions and are realized at the same pitch level, the two input $\mathrm{Hs}$ are fused into a single $\mathrm{H}$ in the output of the phonology. To account for the fact that Fusion does not apply to Pattern $3 \mathrm{~b}$ forms with an object prefix such as $m u[\beta e ́ ! k-e ́]$ 'shave him!', Fusion must be ordered before the Hs become adjacent, or the context in which Fusion applies must somehow be restricted. Fusion 
could be restricted such that it applies only across morphological boundaries, e.g., across the left or right edge of the stem. ${ }^{10}$

Alternatively, we could follow the approach of (20b) that downstep is triggered only by L tones intervening between Hs; adjacent surface Hs and a single multiply linked $\mathrm{H}$ have the same phonetic output-each $\mathrm{H}$-toned mora is realized at the same pitch level. Under this approach, a rule of Default L Insertion would be required to insert $\mathrm{L}$ tones on any toneless moras. In the one case where there is downstep-in Pattern 3b forms with an object prefix such as $m u[\beta e ́ ! k-e ́]$ 'shave him!'-L would be inserted before the two Hs become adjacent, the L dislodged by one of the Hs. There does not appear to be any strong empirical evidence in Tura for choosing between these two approaches to downstep in Tura.

Turning now to the tonal pattern of VCV stems with an object prefix, we can note that one additional rule is necessary to account for these forms. The rules presented thus far predict the unattested form *a-li-mw[áár-á] (from intermediate $\left.a-l i-m u\left[a^{\prime} r-a ́\right]\right)$, where the $\mathrm{H}$ of the object prefix and the melodic $\mathrm{H}$ are realized at the same pitch level on each half of the resyllabified syllable at the stem boundary. The fall in the attested form $a-l i-m w[a ́ a r-a ́$ ' 'he will operate on him' is created by the late rule in $(21)$, which delinks the second $H$ within a syllable when that $\mathrm{H}$ is also linked to a mora in the following syllable. We see in section 4 that when the second of two Hs within a syllable is not multiply linked, the two Hs are realized at the same pitch level, i.e., as a level H-toned long syllable.

(21)

$[H-H]_{\sigma}$ Delinking

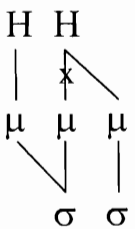

A representative derivation of VCV stems with an object prefix is given in (22), showing the application of $[\mathrm{H}-\mathrm{H}]_{\sigma}$ Delinking after MHA, Minimal Spread, and Hiatus Resolution." In longer stems such as $a$-li-mw[íimb-ír-á] 'he will sing for

\footnotetext{
${ }^{10}$ The only context where adjacent $\mathrm{Hs}$ realized at the same pitch level do not straddle one of the edges of the stem is when the negative prefix si- precedes the Pattern 4a Remote Past tense prefix $a^{-}$, yet the Hs are still realized at the pitch level. See fn. 22.

${ }^{11}$ We can reject the possibility of restating Minimal Spread as a conditional rule that requires the mora immediately preceding the target to be toneless since Minimal Spread freely spreads
} 
him', no further analysis is necessary, as rules given thus far put the tones in the correct positions, and the vowel hiatus resolution strategies will create a falling tone from an intermediate sequence of $\mathrm{V}+\mathrm{V}$.

(22) Pattern la $+O P, V C V$ stem: a-li-mw[1ir-á] 'he will kill him'

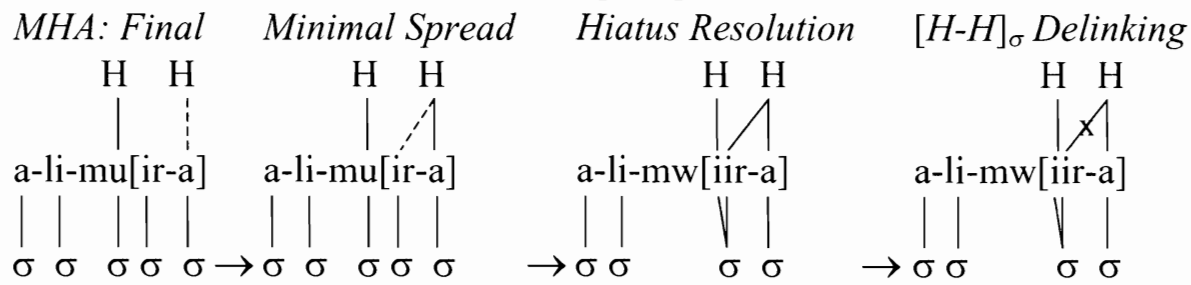

The reflexive $e_{-}{ }^{H}$ contributes an underlying $H$ that surfaces on all moras of the stem-initial syllable in Patterns 3-4, e.g., Pattern 3a y-ee[káánguluul-é] 'he untied himself', cf. a[fuunduluul-e] 'he unknotted'. However, the $\mathrm{H}$ of the reflexive does not surface in Patterns 1-2, e.g., Pattern la a-ly-ee[kaangúlúl-á] 'he will untie himself'. The reflexive is analyzed here as an underlying floating $\mathrm{H}$, like a melodic $\mathrm{H}$. It is assigned to all moras of the stem-initial syllable by the rule of Object H Assigment (OHA: $\sigma 1)$ in (23). This rule requires the target moras as well as the moras of the second syllable of the stem, if there is one, to be toneless. In other words, if there is already a melodic $\mathrm{H}$ on the first or second syllable of the stem, OHA does not apply. Additionally, this rule applies only to floating Hs that are morphologically object prefixes, i.e., not melodic Hs.

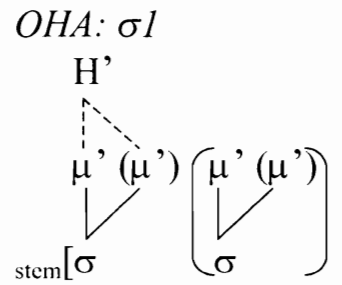

( $\mathrm{H}$ is contributed by an object prefix)

the melodic $\mathrm{H}$ to all moras of the initial syllable of $\mathrm{C}$-initial disyllabic stems preceded by a $\mathrm{H}$ toned prefix. It also cannot be that $\mathrm{H}$ must not be preceded by $\mathrm{H}$ within the syllable-such representations are in fact found in Pattern 2, and, moreover, Hiatus Resolution has not yet applied in the present forms, so the pre-stem mora and the stem-initial mora are not yet part of the same syllable. Incidentally, in the nearby Khayo dialect, Pattern 1a tenses have a rule of Minimal Spread that does require the mora before the target to be toneless (Marlo 2009). 
The derivation in (24) shows that MHA and the rules of leftward spreading derive the placement of the melodic $\mathrm{H}$ on the stem. Since the melodic $\mathrm{H}$ occupies the second syllable of the stem, OHA fails to assign the reflexive $\mathrm{H}$ to the stem. ${ }^{12}$

Pattern $1 a+O P_{\text {Refl: }}$ a-ly-ee[karááng-ír-á] 'he will fry for himself' MHA: Final

Minimal Spread

$\mathrm{H}$

$\mathrm{H}$

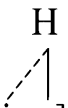

Unbounded Spread

a-li-e[karaang-ir-a] $\rightarrow$ a-li-e[karaang-ir-a]

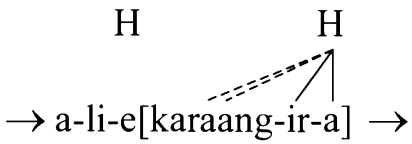

$O H A: \sigma 1$

Hiatus Resolution

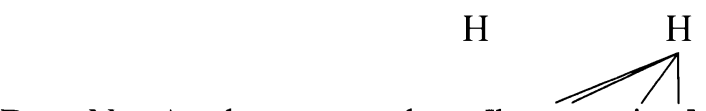

Does Not Apply $\rightarrow$ a-ly-ee[karaang-ir-a]

In an earlier version of this paper available on the author's webpage, the Pattern la tonal properties were accounted for by a rule that spreads the melodic $\mathrm{H}$ iteratively left across the stem, followed by a rule that delinks $\mathrm{H}$ from all moras of the initial syllable of trisyllabic and longer stems. As discussed in the earlier draft, the delinking rule suffers conceptually under most theories of locality since it applies only to a $\mathrm{H}$ multiply linked to moras in the first three syllables of the stem. The choice of the Spread+Delink analysis is motivated mostly by analysisinternal factors-in particular, by a guiding assumption that there are only two simple rules of MHA in Tura: one rule assigning the melodic $\mathrm{H}$ to the moras of the stem-initial syllable and one rule assigning the melodic $\mathrm{H}$ to the stem-final mora. The Conditional Spread analysis adopted here is considered but rejected since as noted there "the entire melodic tonal system of Tura would have to be reanalyzed" to make the analysis to work.

The present account indeed reanalyzes the entire Tura melodic tone system, rejecting the assumption that there are only two MHA rules. Although the present approach involves several MHA rules that are more complex than the two in the former account, it has various advantages over the earlier analysis. The rules of this analysis respect conventions of locality, and tonal derivations are more transparent than in the former analysis. The present analysis is also very similar to the

${ }^{12}$ There does not appear to be any empirical evidence to determine whether the $\mathrm{H}$ of the reflexive persists in the phonological representation. The $\mathrm{H}$ has no phonetic effect, so a late rule of Stray Erasure could be posited to delete the $\mathrm{H}$ of the reflexive. 
analysis of the tonal system of the closely related Khayo dialect (Marlo, to appear), which cannot be accounted under a Spread+Delink approach or under the assumption that there are only two MHA rules in the language. The present analysis is therefore more plausible on both synchronic and diachronic grounds.

3.2 Pattern 1b. The Pattern $1 \mathrm{~b}$ tonal melody is found in the tenses in (25). This section discusses the tonal patterns of the Near Future. Paradigms for each of these other tenses are provided in section 10.2 in the appendix.

(25) Pattern 16 tenses

$\begin{array}{lll}\text { Immediate Past } & \text { Near Future } & \text { Near Future Negative } \\ \text { Remote Future } & \text { Remote Future Negative } & \end{array}$

The stem tone patterns of Patterns $1 \mathrm{a}$ and $1 \mathrm{~b}$ are identical; the only tonal differences between these two Patterns derive from the fact that Pattern $1 \mathrm{~b}$ forms have a $\mathrm{H}$-toned tense prefix, making them tonally identical to Pattern 1a forms with an object prefix. As the data in (26) show, the tense prefix lá-surfaces $\mathrm{H}$, and the usual Pattern 1 stem tone patterns obtain. Monosyllabic and disyllabic stems surface with the melodic $\mathrm{H}$ on all moras of the stem, and trisyllabic and longer stems surface with the melodic $\mathrm{H}$ on all moras after the stem-initial syllable. When the melodic $\mathrm{H}$ surfaces on the stem-initial mora in monosyllabic and disyllabic stems, immediately following the $\mathrm{H}$ of the tense prefix, the two Hs are realized at the same pitch level. These basic tonal patterns of Pattern $1 \mathrm{~b}$ can be captured with the same rules governing the realization of the melodic $\mathrm{H}$ as in Pattern 1a: MHA: Final, Minimal Spread, and Unbounded Spread.

(26) Near Future 'he will ...'

$\begin{array}{llll}\text { a-lá[fw-á] } & \text { 'die' } & \text { a-lá[tsy-á] } & \text { 'go', } \\ \text { a-lá[ßék-á] } & \text { 'shave' } & \text { a-lá[kúl-á] } & \text { 'buy' } \\ \text { a-lá[tééx-á] } & \text { 'cook' } & \text { a-lá[xwéés-á] } & \text { 'pull' } \\ \text { a-lá[ßakál-á] } & \text { 'set out to dry' } & \text { a-lá[ßukúl-á] } & \text { 'take' } \\ \text { a-lá[karááng-á] } & \text { 'fry' } & \text { a-lá[fuundix-á] } & \text { 'knot' } \\ \text { a-lá[saangáál-á] } & \text { 'be happy' } & \text { a-lá[fuundúlúx-á] } & \text { 'unknot' }\end{array}$

The data in (27) show the tonal patterns of $\mathrm{V}$-initial stems in Pattern $1 \mathrm{~b}$, which are parallel to the forms of $\mathrm{V}$-initial stems with an object prefix in Pattern 1a. A HØ falling tone is realized on the derived long stem-initial syllable, and 
subsequent moras are $\mathrm{H}$. VCV stems have a stem-initial fall due to $[\mathrm{H}-\mathrm{H}]_{\sigma}$ Delinking, delinking $\mathrm{H}$ from the stem-initial moras after Minimal Spread.

Near Future $V$-initial stems 'he will ...'

\begin{tabular}{|c|c|c|}
\hline a-1[éemb-á] & 'sing' & a-1[óol-á] \\
\hline a-1[áaníx-á] & 'set out to dry' & a-1[éerúx-á] \\
\hline a-1[áandíı-á] & 'write' & a-l[éeß’́ı́rı́r-á] \\
\hline
\end{tabular}

The data in (28) show that the $\mathrm{H}$ of an object prefix is deleted following the $\mathrm{H}$-toned tense prefix in Pattern $1 \mathrm{~b}$. In these forms, the tense prefix surfaces $\mathrm{H}$, the object prefix surfaces toneless, and the otherwise typical stem tone patterns occur: monosyllabic and disyllabic stems surface with the melodic $\mathrm{H}$ on all stem moras, and trisyllabic and longer stems surface with the melodic $\mathrm{H}$ on all moras after the stem-initial syllable.

(28) Near Future + OP 'he will ... him'

\begin{tabular}{|c|c|c|c|}
\hline a-lá-mu[ry-á] & 'fear' & a-lá-mu[xw-á] & 'pay dowry' \\
\hline a-lá-mu[ßék-á] [O] & 'shave' & a-lá-mu[lól-á] [O] & 'see' \\
\hline a-lá-mu[línd-á] [O] & 'wait for' & a-lá-mu[réé $\beta$-á] [O] & 'ask' \\
\hline a-lá-mu[ßukúl-á] & 'take' & a-lá-mu[lexúúl-á] & 'release' \\
\hline a-lá-mu[ßoolól-á] & & a-lá-mu[siindı́x-á] & 'push’ \\
\hline a-lá-mu[liingéér-á] & 'watch' & a-lá-mu[ß̧otóóxán-á] & 'go around' \\
\hline
\end{tabular}

The 1sg object prefix has the same tonal patterns as other object prefixes: the $\mathrm{H}$ of the object prefix is deleted after the $\mathrm{H}$-toned tense prefix, and the usual Pattern 1 stem tone patterns are found. In these examples, shown in (29), lengthening of the vowel before the nasal creates a falling tone in the pre-stem syllable.

(29) Near Future $+O P_{1 s g}[\mathrm{O}]$ 'he will ... me'

$\begin{array}{llll}\text { a-láa[ry-á] } & \text { 'fear' } & \text { a-láa[mbék-á] } & \text { 'shave' } \\ \text { a-láa[nźir-á] } & \text { 'kill' } & \text { a-láa[nínd-á] } & \text { 'wait for' } \\ \text { a-láa[ndééß-á] } & \text { 'ask' } & \text { a-láa[nyimbir-á] } & \text { 'sing for' } \\ \text { a-láa[mbukúl-á] } & \text { 'take' } & \text { a-láa[mboolól-á] } & \text { 'untie' } \\ \text { a-láa[ndexúúl-á] } & \text { 'release' } & \text { a-láa[niingéér-á] } & \text { 'watch' } \\ \text { a-láa[nzasyáák-1́r-á] } & \text { 'split for' } & \text { a-láa[mbodóóxán-á] } & \text { 'go around' }\end{array}$

The data in (30) show the tonal patterns of Pattern $1 \mathrm{~b}$ forms with an object prefix and a V-initial stem. In these forms, the tense prefix always surfaces $\mathrm{H}$. In 
VCV stems, the resyllabified stem-initial syllable is realized with a rise-the expected combination of the toneless mora of the object prefix and a $\mathrm{H}$ on the steminitial mora. In longer stems, the stem-initial mora is toneless since Unbounded Spread does not spread onto the moras of the stem-initial syllable, and subsequent moras are $\mathrm{H}$.

(30) Near Future + OP V-initial stems 'he will ... him'

a-lá-mw[aár-á] [O] 'operate on' a-lá-mw[ïrr-á] [O] 'kill'

a-lá-mw[iimb-ir-á] 'sing for' a-lá-mw[aand'́1k-ir-á] 'write for'

The tonal pattern of Pattern $1 \mathrm{~b}$ forms with an object prefix motivate the common tonal rule known as Meeussen's Rule, provided in (31), which deletes the second of two adjacent Hs. Meeussen's Rule is ordered early and affects only underlyingly adjacent Hs, i.e., prefixes. The melodic $\mathrm{H}$ is never affected by Meeussen's Rule because the rule applies before any melodic Hs are assigned to the stem.

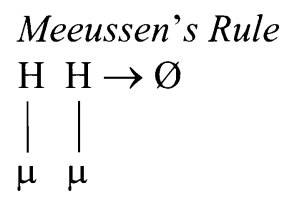

The derivation in (32) shows that Meeussen's Rule causes the deletion of the $\mathrm{H}$ of the object prefix after the $\mathrm{H}$ of the tense prefix in Pattern $1 \mathrm{~b}$ forms, and then the rules determining the surface position of the melodic $\mathrm{H}$ apply.

(32) Pattern $1 b+O P$ : a-lá-mu[ßotóóxán-á] 'he will go around him' Meeussen's Rule

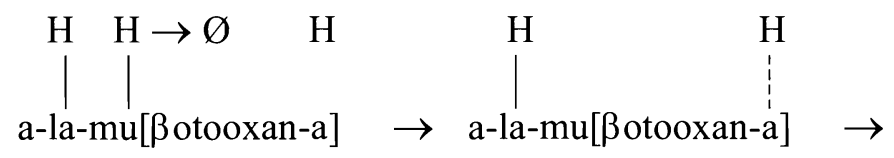

Minimal Spread

Unbounded Spread

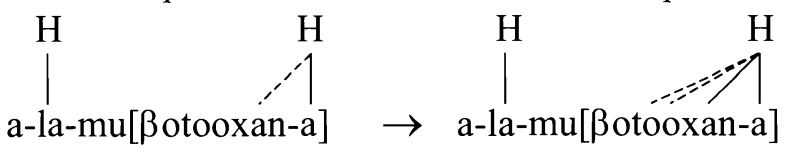


The data in (33) show the tonal patterns of the reflexive prefix in Pattern $1 \mathrm{~b}$, which show no significant tonal difference compared to Pattern $1 \mathrm{~b}$ forms lacking an object prefix or forms with a $\mathrm{CV}$ - object prefix. The vowel of the reflexive prefix forms a single long syllable with the tense prefix, and the $V+V$ sequence is predictably realized as a fall: /lá+e/ $\rightarrow$ [lée].

$\begin{array}{llll}\text { (33) } & \text { Near Future }+O P_{\text {Refl }}[\mathrm{O}] \text { 'he will ... } & \text { himself' } \\ \text { a-l-ée[ry-á] } & \text { 'fear' } & \text { a-l-ée[ßék-á] } & \text { 'shave' } \\ \text { a-l-ée[y-1r-á] } & \text { 'kill' } & \text { a-1-ée[fwáál-á] } & \text { 'dress' } \\ \text { a-1-ée[fumír-á] } & \text { 'stab' } & \text { a-1-ée[y-imb-1r-á] } & \text { 'sing for' } \\ \text { a-l-ée[lexúúl-á] } & \text { 'release' } & \text { a-l-ée[ßoolól-á] } & \text { 'untie' } \\ \text { a-l-ée[y-asyáák-1r-á] } & \text { 'split for' } & \text { a-l-ée[karááng-1r-á] } & \text { 'fry for' } \\ \text { a-l-ée[kaangúlúl-á] } & \text { 'untie' } & & \end{array}$

The $\mathrm{H}$ of the reflexive does not surface in Pattern $\mathrm{lb}$ for the same reason as in Pattern 1a: the $\mathrm{H}$ of the reflexive cannot be assigned to the moras of the steminitial syllable because the melodic $\mathrm{H}$ occupies the moras of one of the first two stem syllables.

\section{Pattern 2.}

The Pattern 2 tonal melody is found in many of the negative forms of Pattern 1 tenses, although this melody has different properties from the Pattern 1 melody. Unlike the Pattern 1 melodic $\mathrm{H}$, the Pattern 2 melodic $\mathrm{H}$ surfaces at the left edge of the stem and does not extend rightward to the final. Additionally, unlike the Pattern 1 melodic $\mathrm{H}$, the Pattern 2 melodic $\mathrm{H}$ fails to be realized on monosyllabic stems after a H-toned prefix. However, the two melodies share the property that the melodic $\mathrm{H}$ surfaces after a $\mathrm{H}$-toned prefix in disyllabic and longer stems. As in Pattern 1, there are two sub-types of Pattern 2: Pattern 2a, which has a toneless tense prefix, and Pattern 2b, which has a H-toned tense prefix.

4.1 Pattern 2a. Pattern 2a includes the tenses in (34), which are the negative counterparts of the Pattern 1a tenses. This section deals with the Indefinite Future Negative. Data from the other tenses are provided in section 10.3 in the appendix. 
The Pattern 2a melodic $\mathrm{H}$ is found on the moras of the initial syllable of monosyllabic (35a) and disyllabic (35b) stems and on the moras of the second syllable of trisyllabic and longer stems (35c). The negative prefix sí- and enclitic tá are $\mathrm{H}$-toned but do not interact phonologically with other tones. When sí-is followed by a toneless $\mathrm{V}$-initial subject marker, such as the $3 \operatorname{sg} a$-, a falling tone surfaces on the derived long vowel-the expected combination of $\mathrm{V}+\mathrm{V}$. When the melodic $\mathrm{H}$ is realized on the word-final mora in monosyllabic stems (35a), the $\mathrm{H}$ of the following negative marker $t a ́$ is realized at the same pitch level as the preceding $\mathrm{H}$.

(35) Indefinite Future Negative 'he (a-) / they ( $\beta \mathrm{a}-)$ will not ...'
a. s-áa-li[fw-á] tá [O] 'die'
śi-ßa-li[tsy-á] tá [O]
'go'
b. sí- $\beta \mathrm{a}-\mathrm{li}[\beta \mathrm{e} k-\mathrm{a}]$ tá
'shave'
sí-ßa-li[lól-a] tá
'see' sí-ßa-li[rínd-a] tá
'wait'
sí- $\beta$ a-li[réé $\beta-a]$ tá
'ask'
c. ś́- $\beta a-l i[\beta u k u ́ l-a]$ tá 'take' ś́- $\beta$ a-li[siinđíx-a] tá 'push' śi-ßa-li[lomálom-a] tá 'talk'
sí- $\beta$ a-li[karááng-a] tá sí- $\beta$ a-li[liingéér-a] tá
'fry'
'watch'

As shown by the data in (36), $\mathrm{V}$-initial stems realize the melodic $\mathrm{H}$ on the expected positions-the initial mora of VCV stems (36a) and moras of the second syllable of longer stems (36b). In VCV stems, the toneless mora of the tense prefix and the stem-initial $\mathrm{H}$ predictably combine to form a rising tone.

(36) Indefinite Future Negative $V$-initial stems 'they will not ...'

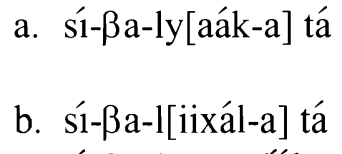
'weed'

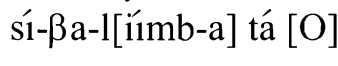
'sing'

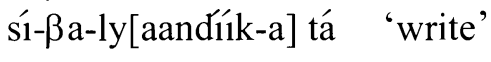
sí- $\beta a-1[i i r u ́ x-a]$ tá
'run'

In Pattern 2a forms with an object prefix, the $\mathrm{H}$ of the object prefix surfaces in its input position, immediately before the verb stem. With the exception of monosyllabic stems, the tonal patterns are the same as when there is no object prefix: the melodic $\mathrm{H}$ surfaces on the moras of the initial syllable of disyllabic stems (37b), where it is realized at the same pitch level as the $\mathrm{H}$ of the object prefix, and on the moras of the second syllable of trisyllabic and longer stems (37c). 
Unlike forms lacking a $\mathrm{H}$-toned prefix, the melodic $\mathrm{H}$ is not realized on monosyllabic stems (37a) following the H-toned object prefix.

(37) Indefinite Future Negative $+O P$ 'they will not ... him'

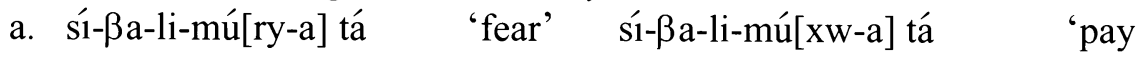
dowry'

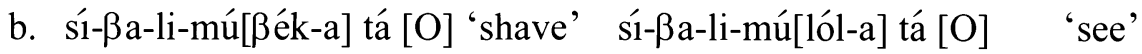

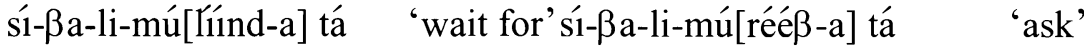

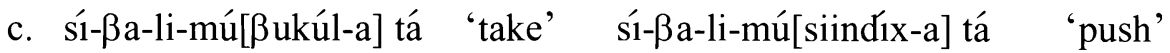

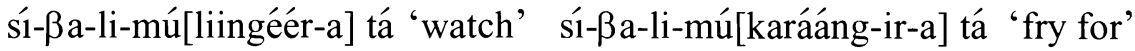

When an object prefix co-occurs with a $\mathrm{V}$-initial stem, the $\mathrm{H}$ of the object prefix and the melodic $\mathrm{H}$ surface as a level $\mathrm{H}$ on the resyllabified initial syllable of VCV stems (38a). In trisyllabic and longer stems (38b), the $\mathrm{H}$ of the object prefix surfaces as a fall in combination with the toneless stem-initial mora, and the melodic $\mathrm{H}$ surfaces on the moras of the second syllable of the stem.

(38) Indefinite Future Negative + OP V-initial stems 'they will not ... him'

a. śi-ßa-li-mw[áár-a] tá

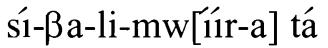
'operate on' 'kill'

b. si-ßa-li-mw[íxásy-a] tá

'help sit' ś1-ßa-li-mw['imb-ír-a] tá 'sing for' ś1-ßa-li-mw[áandínk-ir-a] tá 'write for' ś1-ßa-li-mw[áasyáák-ir-a] tá 'split for'

Indefinite Future Negative forms have not been elicited with the reflexive, but reflexive forms have been collected in another Pattern $2 \mathrm{a}$ tense, the Present Negative. As in Pattern 1, the reflexive has no surface tonal effect in the Pattern 2a forms in (39). The reflexive surfaces toneless, and the melodic $\mathrm{H}$ surfaces in the normal positions: on the lone mora of monosyllabic stems, on all moras of the initial syllable of disyllabic stems, and on all moras of the second syllable of trisyllabic and longer stems. ${ }^{13}$

${ }^{13}$ These forms lack the negative enclitic tá, suggesting that this marker is not obligatory. This is not entirely unexpected since the negative enclitic is not found in the closely related Nyala- 


\begin{tabular}{|c|c|c|c|}
\hline \multicolumn{4}{|c|}{ Present Negative $+O P_{\text {Refl }}[\mathrm{O}]$ 'he is not ...ing himself' } \\
\hline ś́-y-ee[ry-á] & 'fear' & sí-y-ee[ßék-a] & 'shave' \\
\hline ś1-y-ee[lol-ááng-a] & 'see' & ś1-y-ee[fwaal-ááng-a] & 'dress' \\
\hline ś́-y-ee[ßoolól-aang-a] & 'untie' & ś1-y-ee[lexúúl-aang-a] & 'release' \\
\hline śl-y-ee[liingéér-aang-a] & 'watch & & \\
\hline
\end{tabular}

The Pattern 2 tonal patterns are analyzed using the rules in (40). The melodic $\mathrm{H}$ is assigned to all moras of the stem-initial syllable by MHA: $\sigma 1$, a rule that applies only in Pattern 2 contexts. The melodic $\mathrm{H}$ is then shifted by Melodic $\mathrm{H}$ Shift (MHS) from the moras of the stem-initial syllable to the moras of the following syllable, as long as there is another syllable within the stem, i.e., as long as the syllable of the target moras is not final. MHS applies in Pattern 2 and Pattern $4 b-c$ contexts and affects only melodic $\mathrm{Hs}$ (and not the $\mathrm{H}$ of a reflexive or object prefix).

(40)

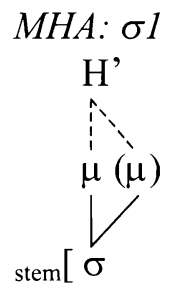

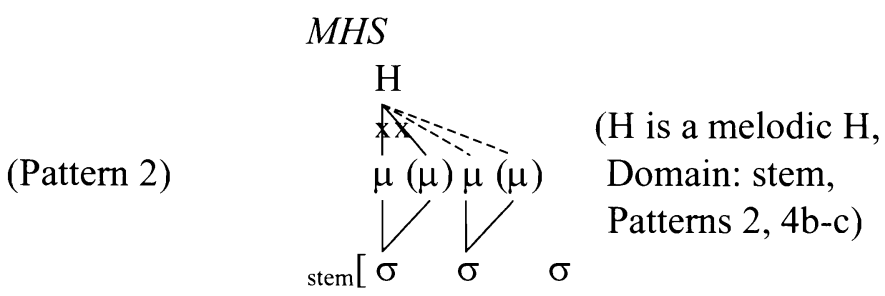

The Pattern 2 melodic $\mathrm{H}$ is first linked to all moras of the stem-initial syllable. In monosyllabic and disyllabic stems (4la-b), no subsequent rules apply. In trisyllabic and longer stems $(41 \mathrm{c})$, the melodic $\mathrm{H}$ is then shifted from all moras of the stem-initial syllable to all moras of the second syllable of the stem.

West dialect (Marlo 2007). Two examples of the Present Negative with the reflexive in the Tura audio paradigm archive are anomalous: sí-y-ee[fúmir- $a]$ and sí-y-ee[fúmir-aang-a], both meaning 'he is not stabbing himself'. These forms are pronounced with $\mathrm{H}$ on the stem-initial mora, while other long stems have $\mathrm{H}$ on the moras of the second syllable. Although possibly erroneous, this variant is noteworthy since Pattern 3-4 forms (and Pattern 1a forms in Wabala's idiolect, see section 8.6) realize the reflexive $\mathrm{H}$ on the moras of the stem-initial syllable. 
(41) Pattern $2 a$

a. Monosyllabic stems: sí-ßa-li[tsy-á] tá 'they will not go'

MHA: $\sigma 1 \quad M H S$

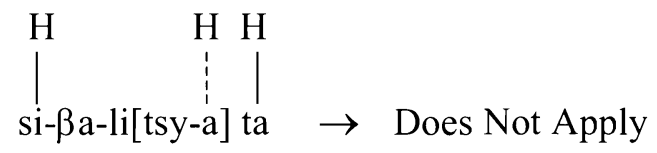

b. Disyllabic stems: ś1- $\beta$ a-li[réé $\beta$-a] tá 'they will not ask' MHA: $\sigma 1 \quad M H S$

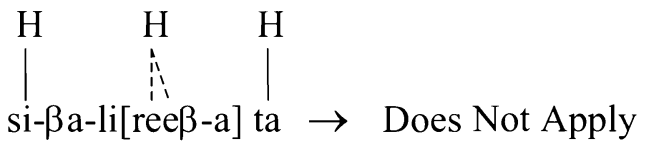

c. Trisyllabic ${ }^{+}$stems: sí-ßa-li[liingéér-a] tá 'they will not watch' MHA: $\sigma 1$

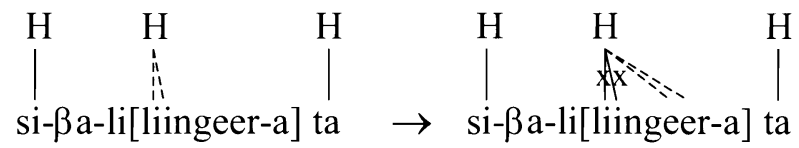

Pattern 2a forms with an object prefix generally succumb to the analysis presented to this point, since the melodic $H$ surfaces on the same position of the stem in disyllabic and longer stems as in forms lacking an object prefix. Monosyllabic stems show the application of one additional rule, $\mathrm{H}[\mathrm{H}]$ Deletion in (42), which deletes the melodic $\mathrm{H}$ from a monosyllabic stem after $\mathrm{H}^{14}$

${ }^{14} \mathrm{H}[\mathrm{H}]$ Deletion reflects a relatively widespread phenomenon in which a final $\mathrm{H}-\mathrm{H}$ sequence surfaces as $\mathrm{H}-\varnothing$. This may be related to the difficulty of perceiving downstepped $\mathrm{H}$ after $\mathrm{H}$ in final position. Crane (2009) reports that pre-pausal 'H obligatorily becomes $\varnothing$ on monosyllabic stems in Shekgalagari (S.31d, Botswana). In the Marachi dialect of Luyia, some potential $\mathrm{H}-\mathrm{H} H$ \# sequences become $\mathrm{H}-\varnothing \#$, but there are different effects depending on phrasemedial vs. phrase-final position and whether the adjacent Hs straddle the stem boundary or are both stem-internal (Marlo 2007). In Tura, H-H\# becomes H-Ø\# only across the stem boundary in melodic contexts outside of Pattern 1. Additionally, the melodic $\mathrm{H}$ is generally realized at the same pitch level as a H-toned prefix, so if final downstep avoidance is the appropriate explanation, it is a diachronic explanation rather than a synchronic one. 


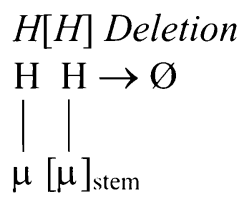

The derivation in (43) shows that after the melodic $\mathrm{H}$ is linked to the stem-initial mora, it is subsequently deleted in monosyllabic stems by $\mathrm{H}[\mathrm{H}]$ Deletion. It is not possible to tell whether $\mathrm{H}[\mathrm{H}]$ Deletion precedes or follows MHS.

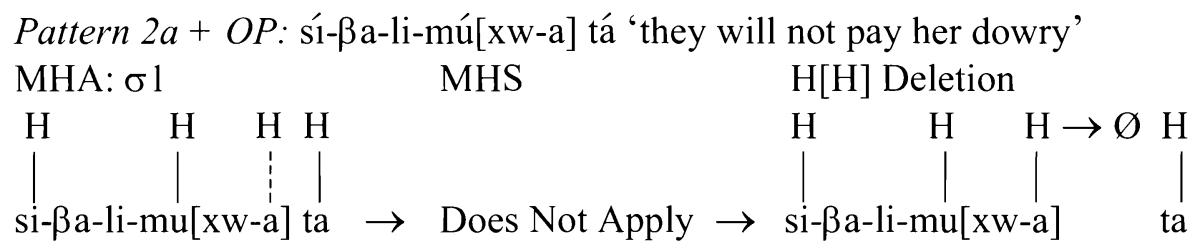

As in Pattern 1, the rule of Doubling does not apply in Pattern 2 forms with

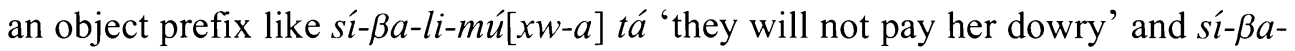
li-mú[liingéér-a] tá 'they will not watch him'. This is due to the fact that Doubling requires the moras of the first two syllables of the stem to be free. Since the stem-initial mora becomes free due to $\mathrm{H}[\mathrm{H}]$ Deletion in monosyllabic stems without triggering Doubling, $\mathrm{H}[\mathrm{H}]$ Deletion must be ordered after Doubling.

The combination of the $\mathrm{H}$-toned object prefix with the melodic $\mathrm{H}$ on the stem-initial mora of VCV stems $\left(V^{\mathrm{V}}+\mathrm{V}^{\prime}\right)$ is realized as level HH, e.g., sí- $\beta a-l i-$ $m w[i ́ r-a] t a ́$ 'they will not kill him'. This is noteworthy since a structurally simi-

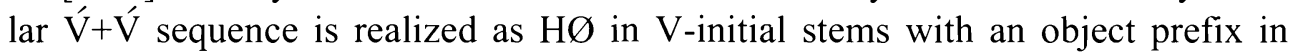
Pattern 1a forms such as $a-l i-m w[$ irr-á] 'he will kill him', due to the fact that [H$\mathrm{H}]_{\sigma}$ Delinking delinks the second of two $\mathrm{Hs}$ in a syllable when $\mathrm{H}$ is linked to a mora in the following syllable. This rule does not apply here because the melodic $\mathrm{H}$ is not linked to a mora in the following syllable.

The reflexive fails to surface in Pattern 2 for essentially the same reason as in Pattern 1. As shown in the derivation in (44), the melodic $\mathrm{H}$ is first assigned to the moras of the stem-initial syllable and then shifts to the moras of the second syllable of the stem by MHS. OHA subsequently fails to apply, since the melodic $\mathrm{H}$ occupies the moras of the second stem syllable. 


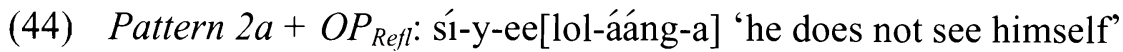
MHA: $\sigma \mathrm{M}$ MHS OHA $\underset{\text { si-a-e[lol-aang-a] }}{\mathrm{H}} \rightarrow \underset{\text { si-a-e[lol-aang-a] }}{\mathrm{H} \mathrm{H}} \rightarrow$ Does Not Apply $\rightarrow$

\section{Hiatus Resolution}

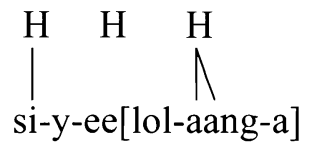

To conclude this section, let us briefly mention an alternative analysis of Pattern 2 adopted in an earlier version of this paper in which Pattern 2 tonal properties are derived from those of Pattern 1. Two generalizations motivate the alternative analysis. First, Pattern 1 and Pattern 2 tenses are morpho-syntactically related: Pattern 2 tenses are the negative counterparts of Pattern 1 tenses. Second, there is a tonal near-parallel between the two melodies: the Pattern 2 melodic $\mathrm{H}$ is generally found on the moras of the leftmost syllable of the corresponding Pattern 1 melodic $\mathrm{H}$. The only difference is in monosyllabic stems following $\mathrm{H}$, in which the Pattern 2 melodic $\mathrm{H}$ does not surface but the Pattern 1 melodic H does. Pattern 2 is therefore derived in the alternative analysis by first applying the Pattern 1 rules of MHA and spreading, followed by a rule that iteratively delinks the right branch of a multiply linked tone from right to left across the stem. For example, sí- $\beta a$-li[liingéér-a] tá 'they will not watch' is derived by assigning the melodic $\mathrm{H}$ to the stem-final mora, followed by leftward spreading rules and then Delinking:

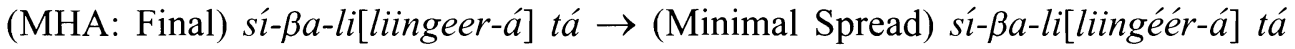
$\rightarrow$ (Delinking) sí- $\beta a-l i[$ liingéér-a] tá.

This alternative is appealing since it correctly predicts a number of parallels between Patterns 1 and 2, including the surface position of the melodic $\mathrm{H}$, and the facts that (i) the melodic $\mathrm{H}$ surfaces after a $\mathrm{H}$-toned prefix (in disyllabic and longer stems), (ii) a $\mathrm{H}$-toned prefix does not double onto the stem-initial mora, and (iii) the $\mathrm{H}$ of the reflexive does not surface on the stem-initial syllable. The fact that the Pattern 2 melodic $\mathrm{H}$ does not surface on a monosyllabic stem after a $\mathrm{H}$-toned prefix is predicted by the analysis noted above for Pattern 1 forms-the rule of Fusion that blocks $\mathrm{H}[\mathrm{H}]$ Deletion in Pattern 1 would not apply in Pattern 2, since Fusion is specific to Pattern 1 contexts, so the melodic H would be deleted from a monosyllabic stem after a H-toned prefix, as in other Patterns. 
The two alternatives are therefore extensionally equivalent. The present analysis has been chosen over the alternative primarily because it is more transparent. Additionally, by assigning the melodic $\mathrm{H}$ directly to the left edge of the stem, the present analysis emphasizes parallels in the surface position of the Pattern 2 and Pattern 4 melodic Hs, allowing the other differences among these melodies to be captured by parameterizing the MHA rules to be sensitive (or not) to the presence or absence of a $\mathrm{H}$ before the target moras. ${ }^{15}$

4.2 Pattern 2b. As indicated in (45), there is one tense in Tura with the Pattern $2 \mathrm{~b}$ tonal properties, the Immediate Past Negative. The affirmative form of this tense, the Immediate Past, is a Pattern $1 \mathrm{~b}$ tense, just as the Pattern 1a Indefinite Future and Present tenses have negative counterparts in Pattern 2a. However, the negative counterparts of other Pattern $1 b$ tenses do not have Pattern $2 b$ counterparts: the Near Future Negative and the Remote Future Negative take the Pattern $1 \mathrm{~b}$ tonal melody, just like their affirmative counterparts.

(45) Pattern $2 b$ tense

Immediate Past Negative

As in Pattern 1, the categorization of Pattern 2 into "a" and "b" subtypes reflects a difference in the underlying tone of the tense prefix: the Immediate Past Negative has a H-toned tense prefix xá-. Pattern $2 \mathrm{~b}$ forms without an object prefix are identical to Pattern 2a forms with an object prefix: the melodic $\mathrm{H}$ is not realized on monosyllabic stems (46a), but it is realized on the moras of the initial syllable of disyllabic stems (46b) and on the moras of the second syllable of trisyllabic and longer stems (46c). The analysis of Pattern $2 b$ forms lacking an object prefix is identical to that of Pattern 2a forms with an object prefix.

(46) Immediate Past Negative 'he did not just ...'
a. sí-y-a-xá[ly-a] tá
'eat'
sí-y-a-xá[tsy-a] tá
'go'
b. sí-y-a-xá[ßék-a] tá [O]
'shave'
ś́-y-a-xá[lól-a] tá [O]
'see' sí-y-a-xá[réé $\beta$-a] tá
'ask'
śr-y-a-xá[tééx-a] tá
'cook'

\footnotetext{
${ }^{15} \mathrm{~A}$ minor challenge posed by the alternative analysis is why the Delinking rule does not apply in other contexts, especially Pattern 1. Delinking would have to be a Pattern-specific rule.
} 

c. ś-y-a-xá[ßakál-a] tá
'set out'
ś1-y-a-xá[ßukúl-a] tá
'take'
ś1-y-a-xá[karáang-a] tá 'fry'
ś1-y-a-xá[ßßoolól-a] tá
'untie'
ś1-y-a-xá[fuundix-a] tá 'knot'
ś1-y-a-xá[liingéér-a] tá
'watch'
ś1-y-a-xá[fuundúlul-a] tá 'unknot'
ś1-y-a-xá[kaangúlul-a] tá
'untie'

Pattern $2 \mathrm{~b}$ forms with $\mathrm{V}$-initial stems are also tonally identical to the corresponding Pattern 2a forms with an object prefix. The prefix $\mathrm{H}$ and stem-initial $\mathrm{H}$ surface as a single long level $\mathrm{H}$ in disyllabic stems (47a)-the predictable combination of $\mathrm{H}+\mathrm{H}-$ while in longer stems $(47 b)$, the prefix $\mathrm{H}$ is realized as a fall through resyllabification with the toneless stem-initial mora, and the melodic $\mathrm{H}$ surfaces on the moras of the second syllable of the stem.

Immediate Past Negative V-initial stems 'he did not just ...'

a. ś1-y-a-x[éémb-a] tá 'sing' sí-y-a-x[ééy-a] tá

'sweep'

b. ś-y-a-x[áaníx-a] tá

'set out'

sí-y-a-x[éerúx-a] tá

'run'

ś́-y-a-x[áandínk-a] tá

'write'

ś-y-a-x[áasyáák-a] tá

'split

wood'

As in Pattern 1b forms with an object prefix, the combination of two $\mathrm{H}$ toned prefixes in Pattern $2 \mathrm{~b}$ results in the deletion of the $\mathrm{H}$ of the object prefix by Meeussen's Rule. The melodic $\mathrm{H}$ is realized in its expected positions: on all moras of the initial syllable of monosyllabic (48a) and disyllabic (48b) stems and on all moras of the second syllable of trisyllabic and longer stems (48c), due to the application of MHA: $\sigma 1$ and MHS. ${ }^{16}$ As in other negative forms when the melodic $\mathrm{H}$ surfaces on the final vowel, the negative enclitic tá is realized at the same pitch level as the preceding melodic $\mathrm{H}$ in monosyllabic stems.

\footnotetext{
${ }^{16}$ There is a variant pronunciation of the monosyllabic stems in the audio paradigm archive that lacks a melodic $\mathrm{H}:$ sí-y-a-xá-mu[xw-a] tá [O] 'he did not just pay dowry', sí-y-a-xá-mu[ry-a] tá [O] 'he did not just fear him', suggesting variation in the order of $\mathrm{H}[\mathrm{H}]$ Deletion and Meeussen's Rule. It may be that these forms are errors or reflect an influence of the closely related Khayo dialect, which also has a toneless monosyllabic stem in this context, e.g., si-y$a-x a ́-m u[r y-a]$ 'he did not just fear him' (Marlo 2009).
} 
(48) Immediate Past Negative $+O P$ ' he did not just ... him'

a. sí-y-a-xá-mu[ry-á] tá [O] 'fear' ś́-y-a-xá-mu[xw-á] tá [O] 'pay dowry'

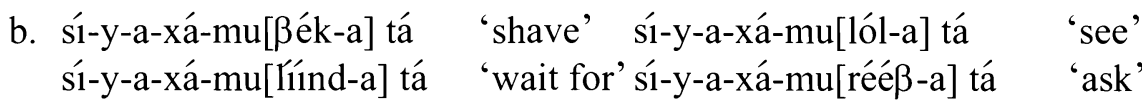

c. ś́-y-a-xá-mu[ßukúl-a] tá 'take'

sí-y-a-xá-mu[lexúúl-a] tá 'release'

sí-y-a-xá-mu[teex-ér-a] tá 'cook for'

sí-y-a-xá-mu[liingéer-a] tá 'watch'

sí-y-a-xá-mu[lomálom-er-a] tá 'speak for'

In VCV stems with an object prefix (49a), there is a rising tone on the derived long stem-initial syllable, the expected combination of $\mathrm{V}+\mathrm{V}$. In longer $\mathrm{V}$ initial stems (49b), the moras of the stem-initial syllable are toneless, and the melodic $\mathrm{H}$ is realized on the moras of the second syllable of the stem.

(49) Immediate Past Negative + OP V-initial stems 'he did not just ... him'
a. sí-y-a-xá-mw[aár-a] tá [O]
ś́-y-a-xá-mw[írr-a] tá [O]
'operate on'
'kill'

b. sí-y-a-xá-mw[iimb-ír-a] tá

'sing for'

sí-y-a-xá-mw[aandúik-ir-a] tá

'write for'

Like other Pattern 1-2 forms, the $\mathrm{H}$ of the reflexive does not surface in Pattern $2 \mathrm{~b}$, and with the exception of the monosyllabic stem, the melodic $\mathrm{H}$ is realized in the expected positions: on the moras of the initial syllable of disyllabic stems and on the second syllable of trisyllabic and longer stems. The $\mathrm{H}$ of the tense prefix $x a ́$ - and the toneless reflexive predictably combine as a fall.

(50) Immediate Past Negative $+O P_{\text {Refl }}[\mathrm{O}]$ 'he did not just ... himself'

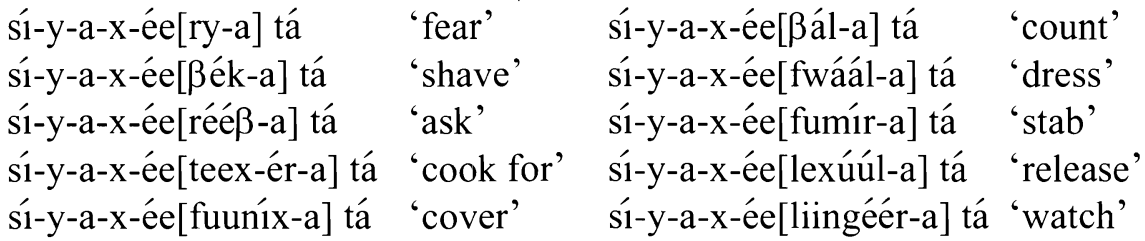


The $\mathrm{H}$ of the reflexive does not surface for the same reasons as in other Pattern 12 forms: the melodic $\mathrm{H}$ is first assigned to the stem, which blocks assignment of the $\mathrm{H}$ of the reflexive to the stem; OHA requires the first two syllables of the stem to be free, as we see in Pattern 3-4 forms below. ${ }^{17}$

\section{Pattern 3.}

Pattern 3 differs from Patterns 1-2 in the position of the melodic $\mathrm{H}$, which surfaces only on the stem-final mora in Pattern 3. There are two Pattern 3 melodic subtypes that differ in the tone of object prefixes: the $\mathrm{H}$ of an object prefix spreads to the stem-initial mora in Pattern $3 \mathrm{a}$, while the $\mathrm{H}$ of an object prefix shifts to the moras of the stem-initial syllable in Pattern 3b. Unlike in Patterns 12 , the reflexive $\mathrm{H}$ surfaces on the moras of the stem-initial syllable in Pattern 3.

5.1 Pattern 3a. As indicated in (51), the lone tense with the Pattern 3a classification is the Hodiernal Perfective.

Pattern 3 a tense

Hodiernal Perfective

The examples in (52)-(53) show that all verb stems, whether C-initial or V-initial, are realized with a $\mathrm{H}$ on the stem-final mora in Pattern $3 \mathrm{a}$.

(52) Hodiernal Perfective 'he (a) / they ( $\beta$ a) ...ed'

\begin{tabular}{|c|c|c|c|}
\hline a[1-iiré] & ‘eat’ & a[nyw-eeré] & 'drink’ \\
\hline a[kon-eré] & ‘sleep’ & a[xin-iré] & 'dance' \\
\hline a[teex-eré] & ‘cook’ & $\mathrm{a}$ [xeeng-eré] & 'cut' \\
\hline a[ßukuul-é] & 'take' & a[xalaak-é] & 'cut' \\
\hline a[karaang-iré] & 'fry' & a[fuundiix-é] & 'knot' \\
\hline$\beta \mathrm{a}[$ liing-aan-é $]$ & 'watch e.o.' & $\beta \mathrm{a}[$ liingaal-iré $]$ & 'watch' \\
\hline$\beta \mathrm{a}$ [saangaal-iré] & 'be happy' & a[fuunduluul-é] & 'unknot' \\
\hline
\end{tabular}

${ }^{17}$ As indicated in fn. 16, the attested examples of monosyllabic stems in Pattern $2 \mathrm{~b}$ show variation in the realization of the melodic $H$. The example in (50) was elicted only once and should be re-checked; I suspect that sí-y-a-x-ée[ry-á] tá is the appropriate but currently unattested form for 'he did not just fear himself'. It is surprising that the melodic $\mathrm{H}$ does not surface here since the floating $\mathrm{H}$ of the reflexive does not trigger $\mathrm{H}[\mathrm{H}]$ Deletion in other contexts, such as Pattern 2a forms like sí-y-ee[ry-á] 'he does not fear himself'. 
(53) Hodiernal Perfective V-initial stems 'he ...ed'
y[aak-iré]
'weed'
y[eey-eré]
'sweep'
y[eeruux-é]
'run'
y[aandiik-iré]
'write'

When an object prefix precedes the stem, the melodic $\mathrm{H}$ is realized on the stem-final mora, and the $\mathrm{H}$ of an object prefix spreads to the stem-initial mora. The examples in (54b) with stem-initial long vowel make it clear that the $\mathrm{H}$ of the object prefix spreads only to the stem-initial mora (and not, e.g., to all moras of the stem-initial syllable). Note that spreading applies in the CVVCV stem, even though the melodic $\mathrm{H}$ occupies the mora of the second stem syllable, cf. Pattern 1-2 forms where the melodic $\mathrm{H}$ blocks spreading of the $\mathrm{H}$ of the object prefix.
Hodiernal Perfective + OP 'he ...ed him (mú) / them (ßá)
a. a-mú[ßék-eré] 'shave'
a-mú[ßúkuul-é] 'take'
a-mú[xúp-iré]
'hit'
'release'
b. a-mú[r-iiré]
'fear'
a-ßá[1́ind-iré]
'wait for'
a-ßá[sáamuul-é] 'beat'
a-ßá[1'ingeer-eré]
'watch'

The data in (55) show that the 1sg object prefix has the same general tonal patterns as $\mathrm{CV}$ - object prefixes: the melodic $\mathrm{H}$ surfaces on the stem-final mora, and the $\mathrm{H}$ of the object prefix surfaces on the mora immediately preceding the stem and on the stem-initial mora. With the nasal prefix, the pre-stem mora is the second half of a derived long vowel, so the $\mathrm{H}$ of the object prefix is realized as part of a rising tone.

$\begin{array}{llll}\text { Hodiernal Perfective }+ & O P_{I s g}[\mathrm{O}] \text { 'he ...ed me' } & \\ \text { y-aá[r-iiré] } & \text { 'fear' } & \text { y-aá[mbék-eré] } & \text { 'shave' } \\ \text { y-aá[nzír-iré] } & \text { 'kill' } & \text { y-aá[níind-iré] } & \text { 'wait for' } \\ \text { y-aá[ndéeß-eré] } & \text { 'ask' } & \text { y-aá[mbúkuul-é] } & \text { 'take' } \\ \text { y-aá[nýmb-iir-é] } & \text { 'sing for' } & \text { y-aá[mbóolool-é] } & \text { 'untie' } \\ \text { y-aá[ndéxuul-iré] } & \text { 'release' } & \text { y-aá[níingeer-eré] } & \text { 'watch' } \\ \text { y-aá[nzásyaak-iir-é] } & \text { 'split for' } & \text { y-aá[mbódooxaan-é] } & \text { 'go around' }\end{array}$

In the $\mathrm{V}$-initial stems in (56), the melodic $\mathrm{H}$ is realized on the stem-final mora, and the $\mathrm{H}$ of the object prefix surfaces as a level $\mathrm{H}$ on the derived steminitial long vowel. 
(56) Hodiernal Perfective + OP V-initial stems 'he ...ed him'

$\begin{array}{llll}\text { a-mw[éény-ere] } & \text { 'want' } & \text { a-mw[1́rr-iré] } & \text { 'kill' } \\ \text { a-mw['ímb-iir-é] } & \text { 'sing for' } & \text { a-mw[áándiik-iré] } & \text { 'employ' }\end{array}$

Unlike in Pattern 1-2, the $\mathrm{H}$ of the reflexive surfaces in Pattern 3. Unlike a prefix $\mathrm{H}$ that doubles from its underlying position to the stem-initial mora, the $\mathrm{H}$ of the reflexive surfaces on all moras of the stem-initial syllable. The only exception to this generalization is in CVVCV stems such as y-ee[r-íiré] 'he feared himself', where the stem-initial and stem-final syllables are adjacent, and the reflexive $\mathrm{H}$ is realized only on the stem-initial mora.

\begin{tabular}{|c|c|c|c|}
\hline y-ee[r-íiré] [O] & 'fear' & y-ee[ßék-eré] & 'shave' \\
\hline y-ee[y-ír-iré] & 'kill' & y-ee[fwáál-iré] [O] & 'dress' \\
\hline y-ee[réé $\beta$-eré] [O] & 'ask' & y-ee[fúmiir-é] [O] & 'stab’ \\
\hline y-ee[y-ímb-iir-é] & 'sing for' & y-ee[ßóólool-é] & 'untie' \\
\hline y-ee[tééx-eer-é] & 'cook for' & y-ee[léxuul-iré] & 'release' \\
\hline y-ee[y-ásyaak-iir-é] & 'spill for' & y-ee[káraang-iir-é] & 'fry for' \\
\hline y-ee[káánguluul-é] & 'untie' & & \\
\hline
\end{tabular}

Although the Pattern 3 melodic $\mathrm{H}$ is realized on the stem-final mora, as in Pattern 1, Pattern 3 forms are not derived by the Pattern 1 rule of MHA. A distinct MHA rule is posited for Pattern 3: MHA: Final II in (58), which applies later in tonal derivations than Pattern 1 MHA.

(58) MHA: Final II

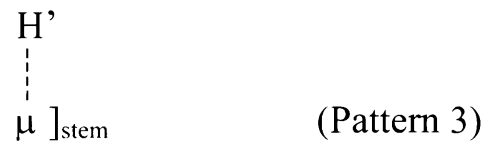

The derivation in (59) show the straightforward account of Pattern $3 \mathrm{a}$ forms lacking an object prefix, where the melodic $\mathrm{H}$ is assigned to the stem-final mora.

(59) Pattern 3a: a[karaang-iré] 'he fried' MHA: Final II

a[karaang-ire] 
The later version of MHA: Final II is motivated by differences between Pattern 3 and Pattern 1 with respect to the rules of Doubling and Object H Assignment, given in (60). Doubling spreads $\mathrm{H}$ from the pre-stem mora to the steminitial mora, provided that the moras of the first two syllables of the stem are free. OHA assigns the $\mathrm{H}$ of the reflexive to the moras of the stem-initial syllable, provided that the target moras and the moras of the second syllable of the stem, if there is one, are free. These rules fail to apply in Pattern 1-2, but both rules apply in Pattern 3. As we see below, Doubling and OHA apply in Pattern 4 when a melodic $\mathrm{H}$ that normally occupies the moras of one of the first two stem syllables does not surface. When the melodic $\mathrm{H}$ does surface on these positions, as in Patterns 1-2, a prefix $\mathrm{H}$ does not double, and the reflexive $\mathrm{H}$ does not surface.

(60)

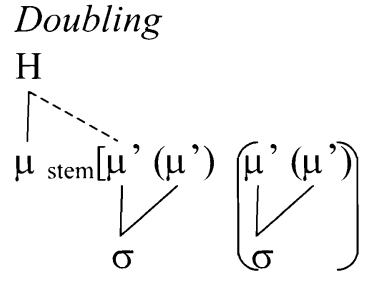

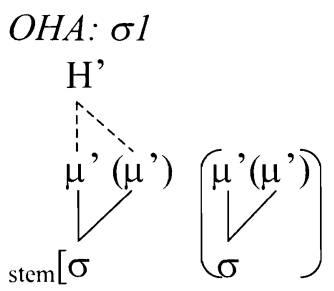

$\mathrm{H}$ is contributed by an OP

Doubling applies in trisyllabic and longer stems (61a) in Pattern 3a since the melodic $\mathrm{H}$ does not occupy the mora of the first two syllables of the stem. Doubling also applies in CVVCV stems (61b), where the melodic H does occupy the moras of the second syllable of the stem. To account for this, MHA: Final II is ordered after Doubling, so the mora of the second stem syllable is free when Doubling applies.

(61) Pattern $3 a+O P$

a. Trisyllabic and longer stems: a-ßá[líingeer-eré] 'he watched them' Doubling MHA: Final II

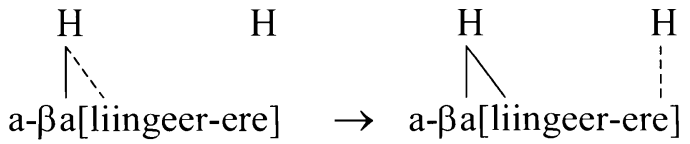

b. CVVCV stems: a-mú[r-riiré] 'he feared him'

Doubling

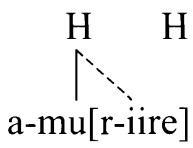

MHA: Final II

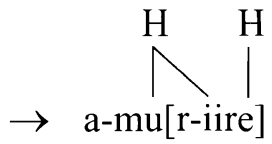


Like Doubling, OHA precedes MHA: Final, so the $\mathrm{H}$ of the reflexive is assigned to the moras of the stem-initial syllable, and then the melodic $\mathrm{H}$ is assigned to the stem-final mora.

(62) Pattern $3 a+O P_{\text {Refl: }}$ y-ee[fwááliré] 'he dressed himself'

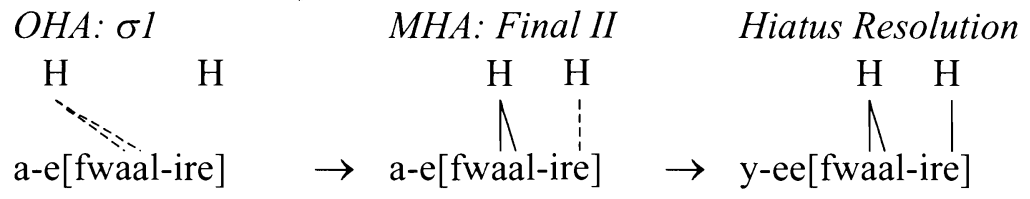

To account for the fact that the $\mathrm{H}$ of the reflexive surfaces on the steminitial syllable as a falling tone before the melodic $\mathrm{H}$ in $y$-ee[r-liré] "he feared himself', a late rule of Pre-H Delinking is posited in (63) to create the falling tone; a level $\mathrm{H}$ is otherwise expected on the stem-initial syllable.

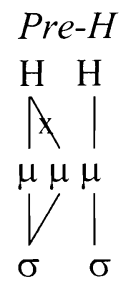

Pre-H Delinking enforces the generalization that CV́V́CV́ sequences are not found in Tura as the output of two distinct Hs. ${ }^{18}$

5.2 Pattern 3b. As indicated in (64), the lone tense with the Pattern $3 b$ tonal properties in Tura is the Imperative $\mathrm{Sg}_{\mathrm{g}}$.

\footnotetext{
${ }^{18}$ All known cases of potential $\left(C V^{\prime}\right)_{\mathrm{H}}\left(C V^{\prime}\right)_{\mathrm{H}}$ are word-final, so the falling tone is created in penultimate position. Other Luyia dialects such as Tachoni restrict falling tones to penultimate position (Odden 2007), but this is not the case in Tura, where falling tones can be derived in any position through resyllabification of $\mathrm{V}+\mathrm{V}$. A reviewer observes that there are structural similarities between Pre-H Delinking and $[\mathrm{H}-\mathrm{H}]_{\sigma}$ Delinking and asks whether the two rules can be combined: "Both have two syllables, the first being bimoraic. Both have two $\mathrm{Hs}$, one of which is multiply linked. Both delete the middle, inner link of the doubly linked H. Both are late rules." These are all excellent observations, but it is unclear how to combine the two rules, given the format of rules assumed here.
} 


\section{(64) Pattern $3 b$ tense \\ Imperative $_{\mathrm{Sg}}$}

The Pattern 3b forms in (65)-(66) are identical to the Pattern 3a examples lacking an object prefix: the stem-final mora surfaces $\mathrm{H}$, irrespective of the number of syllables in the stem. As in Pattern 3a, these forms are accounted for by the application of MHA: Final II.

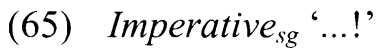

\begin{tabular}{|c|c|c|c|}
\hline [ly-á] & 'eat' & [xw-á] & 'pay dowry' \\
\hline [ßek-á] & 'shave' & [xin-á] & 'dance' \\
\hline [fwiimb-á] & 'cover' & [reeß-á] & 'ask' \\
\hline [teex-á] & 'cook' & [ßakal-á] & 'set out to dry' \\
\hline [ßukul-á] & 'take' & [karaang-á] & 'fry' \\
\hline [fuundix-á] & 'knot' & [fwiimbul-á] & 'uncover' \\
\hline [liingeer-á] & 'watch' & [lomalom-á] & 'talk' \\
\hline
\end{tabular}

(66) Imperative sg -initial stems '...!'

$\begin{array}{llll}\text { [y-ak-á] } & \text { 'weed' } & \text { [imb-á] } & \text { 'sing' } \\ \text { [y-anix-á] } & \text { 'set out to dry' } & \text { [irux-á] } & \text { 'run' } \\ \text { [y-andiik-á] } & \text { 'write' } & \text { [y-asyaak-á] } & \text { 'split' }\end{array}$

Pattern $3 b$ forms with an object prefix have a melodic $\mathrm{H}$ on the stem-final mora, as expected, but the tonal pattern of the object prefix is different from all forms with an object prefix in Tura. The $\mathrm{H}$ of the object prefix does not surface in its underlying position but on the moras of the stem-initial syllable. In monosyllabic stems (67a), the lone stem mora surfaces H. In CVCV stems (67b), the melodic $\mathrm{H}$ on the stem-final mora is downstepped following the $\mathrm{H}$ of the object prefix on the stem-initial mora. In CVVCV stems (67c), the $\mathrm{H}$ of the object prefix surfaces as a fall on the stem-initial syllable before the melodic $\mathrm{H}$, as in $\mathrm{CVVCV}$ stems in Pattern 3a with the reflexive. In longer stems $(67 \mathrm{~d})$, the $\mathrm{H}$ of the object prefix is realized as a level $\mathrm{H}$ on the moras of the stem-initial syllable, as in long stems in Pattern 3a with the reflexive. 
(67) Imperative $_{s g}+O P$ '... him!'
a. mu[ry-é]
'fear'
$\mathrm{mu}[\mathrm{xw}$-é $]$
'pay dowry'
b. mu[ßé'k-é]
'shave'
$\mathrm{mu}[$ rú'm-é]
'send'
c. mu[fwáal-é]
'dress'
$\mathrm{mu}[$ réeß $\beta$-é $]$
'ask'
d. mu[ßúkul-é]
'take'
$\mathrm{mu}[$ lésher-é]
'forgive'
mu[léxuul-é]
'release'
mu[ßóólol-é]
'untie'
mu[tééxer-é] 'cook for'
$\mathrm{mu}[$ [língeer-é]
'look at'
mu[káraang-ir-é] 'fry for'
mu[ßßótooxan-é]
'go around'

The data in (68) show that the 1 sg object prefix has the same tonal properties as other CV- object prefixes. Monosyllabic stems surface $\mathrm{H}$. CVCV stems have a stem-initial $\mathrm{H}$ followed by a downstepped melodic $\mathrm{H}$ on the final mora. The $\mathrm{H}$ of the object prefix surfaces as a fall on the stem-initial syllable in $\mathrm{CVVCV}$ stems, before the melodic $\mathrm{H}$ on the final. In longer stems, the $\mathrm{H}$ of the object prefix is realized as a level $\mathrm{H}$ on all moras of the stem-initial syllable, and the melodic $\mathrm{H}$ is realized on the stem-final mora.
(68) Imperative sg $+O P_{l s g}[\mathrm{O}]$ ' $\ldots$ me!'
[ry-é]
[nźír-é]
[ndée $\beta$-é]
[mbúkul-é]
[mbóólol-é]
[nzásyaak-ir-é]

'fear'
'kill'
'ask'
'take'
'untie'
'split for'
[mbé'k-é]
[níind-é]
[nýimb-ir-é]
[ndéxuul-é]
[níngaal-é]
[mbódooxan-é]
'shave'
'wait for'
'sing for'
'release'
'watch'
'go around'

When V-initial stems co-occur with an object prefix in Pattern 3b, all forms realize the melodic $\mathrm{H}$ on the stem-final mora and have a rise on the derived long stem-initial syllable-the predictable combination of $\varnothing+\mathrm{H}$. In VCV stems (69a), the melodic $\mathrm{H}$ on the stem-final mora is downstepped, following the $\mathrm{H}$ of the object prefix.

(69) Imperative $_{s g}+$ OP V-initial stems '... him!'
a. mw[aál r-é]
'operate on'
mw[ír réé]
'kill'
b. mw[ímb-ir-é] 'sing for'
mw[aándiik-ir-é] 'write for' 
The $\mathrm{H}$ of the object prefix is realized on all moras of the stem-initial syllable in Pattern 3b, just like the reflexive $\mathrm{H}$ in Pattern 3a. This is analyzed as a twopart process. First, the rule of Wd-Initial Delinking in (70) delinks the $\mathrm{H}$ of an object prefix from word-initial position. The only verbal context in which $\mathrm{Wd}$ Initial Delinking applies is the Pattern 3 Imperative $_{S g}$, since it is the only tense that lacks subject prefixes. ${ }^{19}$

(70)

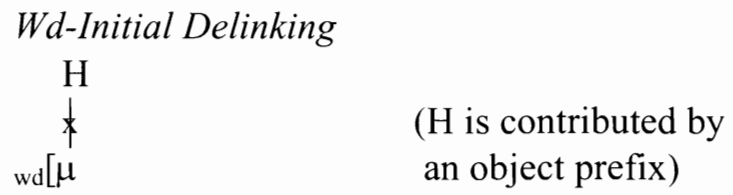

After the $\mathrm{H}$ of the object prefix is set free by Wd-Initial Delinking, it is relinked to the moras of the stem-initial syllable by OHA: $\sigma 1-$ the rule that links the $\mathrm{H}$ of the reflexive to the moras of the stem-initial syllable. The melodic $\mathrm{H}$ is then assigned to the stem-final mora by MHA: Final II. Derivation (71a) shows that in monosyllabic stems it is the $\mathrm{H}$ of the object prefix which surfaces on the stem, not the melodic $\mathrm{H}$. In CVCV stems (71b), the melodic $\mathrm{H}$ immediately follows the $\mathrm{H}$ of the object prefix and is downstepped. As discussed in section 3.1, this could be the result of a rule of Fusion, which is ordered before the melodic $\mathrm{H}$ is assigned to the stem-final (or which applies only across a morphological boundary), or due to a rule of Default L Insertion, which is ordered before MHA: Final II. In stems with an initial long vowel (71d), the $\mathrm{H}$ of the object prefix is linked by OHA to both moras of the syllable, but in CVVCV stems (71c), Pre-H Delinking renders the stem-initial $\mathrm{H}$ into a fall before the melodic $\mathrm{H}$.

(71) Pattern $3 b+O P$

a. Monosyllabic stems: mu[ry-é] 'fear him!'

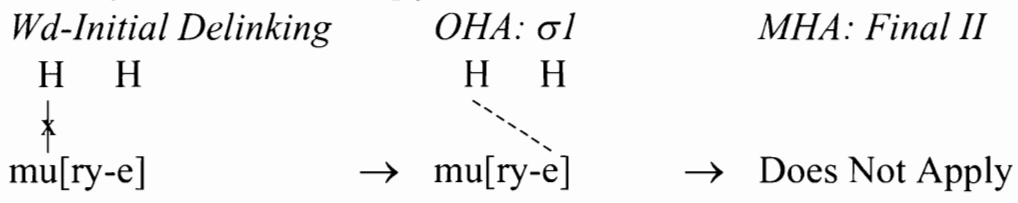

\footnotetext{
${ }^{19} \mathrm{Wd}$-Initial Delinking does not apply to the $\mathrm{H}$ of the negative prefix sí-, which surfaces in word-initial position in various negative tenses, motivating the restriction that only the $\mathrm{H}$ of an object prefix undergoes the rule. We should look to other unstudied contexts, especially nouns, to see if this rule applies in other environments.
} 
b. CVCV stems: mu[ßé'k-é] 'shave him!' Wd-Initial Delinking $O H A: \sigma l$<smiles>Cl[Mg][TlH]</smiles>

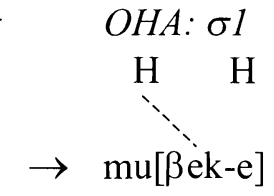
MHA: Final II

c. CVVCV stems: mu[rée $\beta$-é] 'ask him!' Wd-Initial Delinking OHA: $\sigma \mathrm{l}$<smiles></smiles>
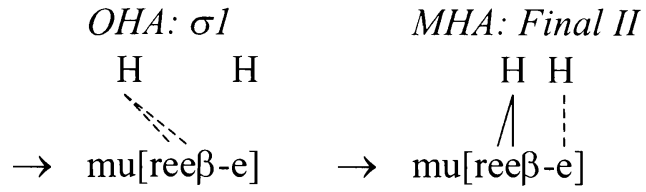

Pre-H Delinking<smiles>[GeH3][TeH]</smiles>

d. Trisyllabic and longer stems: mu[língeer-é] 'watch him!' Wd-Initial Delinking $\quad O H A: \sigma l$

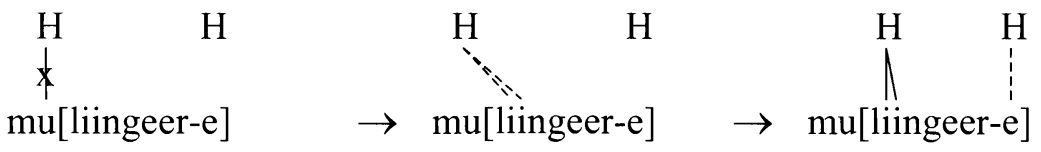

Pattern $3 \mathrm{~b}$ forms with the reflexive prefix are provided in (72). These data are tonally identical to Pattern $3 \mathrm{~b}$ forms with an object prefix and Pattern $3 \mathrm{a}$ forms with the reflexive, with a $\mathrm{H}$ on all moras of the stem-initial syllable and the melodic $\mathrm{H}$ on the stem-final mora.

(72) Imperative sg $+O P_{\text {Refl }^{6} \ldots \text { yourself!' }}$

\begin{tabular}{|c|c|c|c|}
\hline w-e[ry-é] [O] & 'fear' & $\mathrm{w}-\mathrm{e}\left[\beta \mathrm{e}^{\prime} \mathrm{k}-\mathrm{e}\right]$ & 'shave' \\
\hline $\mathrm{w}-\mathrm{e}[\mathrm{y}-1$ '1r-é] [O] & 'kill' & w-e[fwáal-é] [O] & 'dress' \\
\hline w-e[réeß-é] & 'ask' & w-e[fúmir-é] [O] & 'stab' \\
\hline w-e[ý́mb-ir-é] [O] & 'sing for' & w-e[ßóólol-é] & 'untie' \\
\hline w-e[tééxer-é] & 'cook for' & w-e[léxuul-é] [O] & 'release' \\
\hline w-e[y-ásyaak-ir-é] [O] & 'split for' & w-e[káraang-ir-é] & 'fry for' \\
\hline w-e[káángulul-é] [O] & 'untie' & & \\
\hline
\end{tabular}


The analysis of these forms is identical to the Pattern $3 \mathrm{a}$ forms with the reflexive: the $\mathrm{H}$ of the reflexive is assigned to all moras of the stem-initial syllable by OHA, followed by assignment of the melodic $\mathrm{H}$ to the stem-final mora by MHA: Final II. Pre-H Delinking renders level $\mathrm{H}$ into fall before $\mathrm{H}$ in CVVCV stems.

\section{6. $\quad$ Pattern 4.}

Pattern 4 has three subtypes: $4 \mathrm{a}, 4 \mathrm{~b}$, and $4 \mathrm{c}$. In all three, the melodic $\mathrm{H}$ interacts in interesting ways with $\mathrm{H}$-toned prefixes. The melodic $\mathrm{H}$ does not surface after a $\mathrm{H}$-toned prefix in Patterns 4a-b; the melodies differ in that the Pattern 4a melodic $\mathrm{H}$ is consistently realized on the moras of the stem-initial syllable, while the Pattern $4 \mathrm{~b}$ melodic $\mathrm{H}$ is realized on the moras of the first or second syllable of the stem, depending on the number of syllables in the stem, as in Pattern 2. The Pattern $4 \mathrm{c}$ melodic $\mathrm{H}$ surfaces in the same stem positions as the Pattern 2 and Pattern $4 \mathrm{~b}$ melodic $\mathrm{Hs}$ but is realized only after a $\mathrm{H}$-toned prefix.

6.1 Pattern 4a. As indicated in (73), Pattern 4a is found in affirmative and negative forms of the Remote Past. This section is primarily concerned with the description and analysis of the affirmative form of the Remote Past, but a few tonal anomalies are found in the data collected in the Remote Past Negative forms and are discussed at the end of this section.

\section{(73) Pattern 4a tenses}

Remote Past

Remote Past Negative

The Pattern 4a Remote Past has a melodic $\mathrm{H}$, but it does not surface in forms that lack an object prefix. The examples in (74) show that the tense prefix $a$ - and the stem-initial mora are $\mathrm{H}^{20}{ }^{20}$ Crucially, the second mora of a stem-initial long syllable is toneless, as shown by the examples in (74b). The $\mathrm{H}$ on the steminitial mora reflects Doubling of the $\mathrm{H}$ of the tense prefix $a^{-}$. If there were a me-

\footnotetext{
${ }^{20}$ Initial $y$-is epenthetic, blocking an otherwise illicit word-initial long vowel. Initial $y$ - epenthesis before an initial long vowel is also found in the Hesternal Perfective forms in (146) with the $3 \mathrm{sg}$ subject prefix $a$ - and the tense prefix $a$ - and in the Present tense examples in (142) with the 1 sg object prefix $N^{-}$, which causes the initial vowel to lengthen. A complete study of Tura prosody has not been undertaken, and some prosodic alternations in the Remote Past and Remote Past Negative, such as vowel shortening (see Dalgish 1986), are not fully understood.
} 
lodic $\mathrm{H}$ on the stem-initial syllable, as we see below in forms with an object prefix, the melodic $\mathrm{H}$ would occupy both moras of a stem-initial long syllable. The combination of the underlying vowels of the $3 \mathrm{sg}$ subject prefix $a$ - and the tense prefix $a ́$ - is predictably realized as a rising tone.

(74) Remote Past $[\mathrm{O}]$ 'he (y-) / they $(\beta-)$...ed'
a. y-aá[fw-á]
'die'
y-aá[tsy-á]
y-aá[sáß-a]
'beg'
$\mathrm{y}$-aá[xín-a]
'go'
y-aá[ßákal-a]
'set out'
y-aá[ßúkul-a]
'dance'
y-aá[káraang-a]
'fry'
y-aá[léxuul-a]
'take'
y-aá[lómalom-a]
'talk'
b. $y$-aá[rée $\beta$-a]
'ask'
y-aá[téex-a]
'cook'
$y$-aá[fúundix-a]
'knot'
y-aá[sáakuul-a]
'destroy
y-aá[sáambuul-a] 'de-roof'
the roof'
y-aá[fúundix-aang-a] 'knot'
$\beta$-aá[téex-an-ir-a]
'cook for e.o.'

The following Pattern $4 \mathrm{a}$ forms with a $\mathrm{V}$-initial stem have three underlying vowels in hiatus-the 3 sg subject prefix $a$-, the tense prefix $a$-, and the stem-initial vowel-but one of these vowels is not realized on the surface. Although it appears from the quality of the surface $\mathrm{V}$ that one of the underlying prefix $\mathrm{Vs}$ is deleted in the examples in (75), a rising tone emerges, as though it is the stem-initial $\mathrm{V}$ which is deleted.

(75) Remote Past V-initial stems [O] 'he ...ed'

$\begin{array}{llll}\text { y[aák-a] } & \text { 'weed' } & y \text { [eémb-a] } & \text { 'sing' } \\ \text { y[aánix-a] } & \text { 'set out to dry' } y \text { [eérux-a] } & \text { 'run' } \\ \text { y[aándiik-a] } & \text { 'write' } & y \text { [aásyaak-a] } & \text { 'split wood' }\end{array}$

In combination with an object prefix, the $\mathrm{H}$ of the object prefix is deleted after the $\mathrm{H}$ of the tense prefix $a$ - (whose syllable is subject to vowel shortening, see fn. 20). As the examples in (76b) show, the melodic $\mathrm{H}$ is realized on all moras of the stem-initial syllable, which makes it clear that the melodic $\mathrm{H}$ is not present in the forms without an object prefix since only the initial mora of a stem-initial long syllable is $\mathrm{H}$ in those examples, reflecting Doubling of the prefix $\mathrm{H}$. 
(76) Remote Past + OP 'he ...ed him'
a. y-á-mu[ry-á]
'fear'
y-á-mu[ßék-a]
'shave'
y-á-mu[ßúkul-a] 'take'
y-á-mu[léxuul-a] 'release'
y-á-mu[xw-á]
y-á-mu[lól-a]
y-á-mu[léxer-a]
'pay dowry'
'see'
'forgive'
b. y-á-mu[lóónd-a] 'follow'

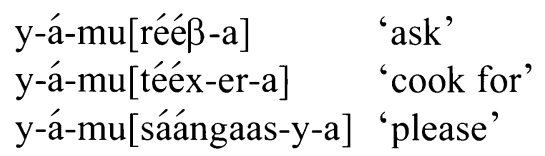

The examples in (77) show that the vowel before the 1sg object prefix is long, and a fall is realized on this long pre-stem syllable. This is parallel to the examples with a CV-object prefix, where the object prefix is toneless, since fall is the predictable combination of $\mathrm{H}+\varnothing$. The melodic $\mathrm{H}$ is realized on all moras of the stem-initial syllable, as in forms with a CV-object prefix.

(77) Remote Past $+O P_{l s g}[\mathrm{O}]$ 'he ...ed me'

$\begin{array}{llll}\text { y-áa[ry-á] } & \text { 'fear' } & \text { y-áa[mbék-a] } & \text { 'shave' } \\ \text { y-áa[nźir-a] } & \text { 'kill' } & \text { y-áa[nínd-a] } & \text { 'wait for' } \\ \text { y-áa[ndéé } \beta-a] & \text { 'ask' } & \text { y-áa[mbúkul-a] } & \text { 'take' } \\ \text { y-áa[ný́mb-ir-a] } & \text { 'sing for' } & \text { y-áa[ndéxuul-a] } & \text { 'release' } \\ \text { y-áa[mbóólol-a] } & \text { 'untie' } & \text { y-áa[nzásyaak-ir-a] } & \text { 'split for' } \\ \text { y-áa[mbódooxan-a] } & \text { 'go around' } & & \end{array}$

The examples in (78) show that in the context of an object prefix and a Vinitial stem, the melodic $\mathrm{H}$ is realized as a rising tone-the predictable combination of the toneless object prefix and the stem-initial melodic $\mathrm{H}$.

Remote Past + OP V-initial stems [O] 'he ...ed him'

$\begin{array}{llll}\text { y-á-mw[aár-a] } & \text { 'operate on' } & \text { y-á-mw[ír-a] } & \text { 'kill' } \\ \text { y-á-mw[ímb-ir-a] } & \text { 'sing for' } & \text { y-á-mw[íxas-y-a] 'make sit' } \\ \text { y-á-mw[aándiik-ir-a] } & \text { 'write for' } & \text { y-á-mw[aásyaak-ir-a] 'split wood for' }\end{array}$

Pattern $4 \mathrm{a}$ forms with the reflexive prefix are provided in (79). These forms have a falling tone on the syllable merging the $\mathrm{H}$ of the tense prefix $a$ - with the toneless reflexive, and each form surfaces with a level $\mathrm{H}$ on the moras of the stem-initial syllable. This contrasts with Pattern $4 \mathrm{a}$ forms that lack an object pre- 
fix, in which the melodic $\mathrm{H}$ does not surface, the $\mathrm{H}$ of the tense prefix doubling to the stem-initial mora, e.g., y-aá[téex-aang-a] 'he was cooking'.

(79) Remote Past $+O P_{\text {Refl }}$ 'he ...ed himself'

$\begin{array}{llll}\text { y-ée[ry-á] [O] } & \text { 'fear' } & \text { y-ée[ßék-a] } & \text { 'shave' } \\ \text { y-ée[y-ir-a] } & \text { 'kill' } & \text { y-ée[rééß-a] } & \text { 'ask' } \\ \text { y-ée[súúng-a] } & \text { 'be proud of' } & \text { y-ée[fúmir-a] } & \text { 'stab' } \\ \text { y-ée[y-ímb-ir-a] } & \text { 'sing for' } & \text { y-ée[y-ándiik-a] } & \text { 'employ' } \\ \text { y-ée[tééx-er-a] } & \text { 'cook for' } & \text { y-ée[káraang-ir-a] 'fry for' }\end{array}$

The Pattern $4 \mathrm{a}$ forms are analyzed with a MHA rule that resembles but is ultimately different from the Pattern 2 MHA rule. This rule, called MHA: $\sigma 1 / \mu$ ' and formalized in (80), assigns $\mathrm{H}$ to all moras of the stem-initial syllable, as long as the target moras and the immediately preceding mora are toneless.

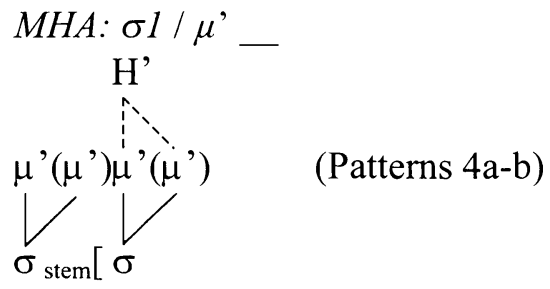

The derivation in (81) shows that the melodic $\mathrm{H}$ fails to be assigned in forms that lack an object prefix because the moras of the stem-initial syllable are immediately preceded by the H-toned tense prefix $a$-. Since the stem-initial mora is free, the $\mathrm{H}$ of the tense prefix then undergoes Doubling.

(81) Pattern 4a: $y$-aá[téex-aang-a] 'he was cooking'

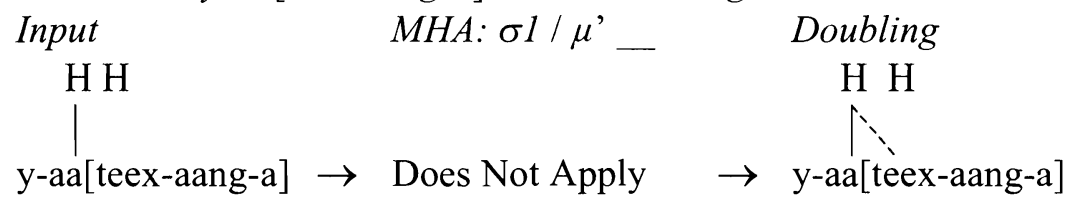

The derivation in (82) shows that when there is an object prefix, the $\mathrm{H}$ of the object prefix is first deleted by Meeussen's Rule. As a result, the mora immediately preceding the stem is toneless, so the melodic $\mathrm{H}$ is assigned to all moras of the stem-initial syllable. 
(82) Pattern 4a +OP: y-á-mu[tééx-er-a] 'he cooked for him'

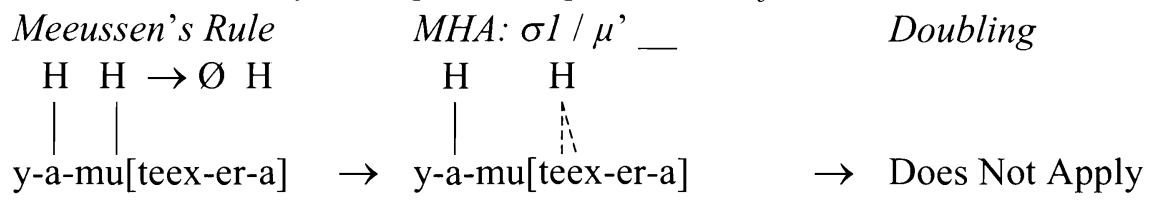

The Pattern 4a forms with the reflexive raise the question as to whether the $\mathrm{H}$ that surfaces on the stem-initial syllable is the $\mathrm{H}$ of the reflexive or the melodic $\mathrm{H}$. It is not possible to tell from the Pattern $4 \mathrm{a}$ forms alone since the reflexive $\mathrm{H}$ and the melodic $\mathrm{H}$ both surface on all moras of the stem-initial syllable. In Pattern $4 \mathrm{~b}$, there is evidence that it is the $\mathrm{H}$ of the reflexive which surfaces and not the melodic H. Since Pattern $4 \mathrm{a}$ and Pattern $4 \mathrm{~b}$ are analyzed here as having the same rule of MHA, this analysis treats the $\mathrm{H}$ in Pattern 4a forms with the reflexive as the reflexive $\mathrm{H}$. This is accounted for by OHA ordering before MHA. Once the $\mathrm{H}$ of the reflexive is assigned to the moras of the stem-initial syllable, the melodic $\mathrm{H}$ is blocked from being assigned to the stem.

Before turning to the Remote Past Negative, let us briefly address an alternative analysis, adopted in a previous draft of this paper, which treats the failure of the Pattern 4a-b melodic $\mathrm{H}$ to surface after a $\mathrm{H}$-toned prefix as the deletion of the melodic $\mathrm{H}$ from the stem-initial position by Meeussen's Rule after it has been assigned to the stem. Within the analysis developed to this point, the "assign then delete" analysis is problematic since it would require ordering relationships between MHA rules and Meeussen's Rule that are incompatible with other ordering relationships among the MHA rules. We have seen that the the melodic $\mathrm{H}$ surfaces after a H-toned prefix in Patterns 1-3. This would require the Pattern 4a-b rule of MHA to precede Meeussen's Rule, which precedes the Pattern 1-3 rules of MHA. As is discussed further in section 7, the fact that the reflexive $\mathrm{H}$ is realized in Patterns 4a-c but not Patterns 1-2 provides evidence for ordering Pattern 1-2 MHA rules before the Pattern 4a-c MHA rules. The present approach allows the derivation of Pattern $4 \mathrm{a}-\mathrm{b}$ forms to be more transparent, and it extends naturally to a formulation of Pattern $4 \mathrm{c}$ MHA that requires a preceding $\mathrm{H}$. If the absence of a melodic $\mathrm{H}$ on the surface is uniformly analyzed as the result of Meeussen's Rule, then the analysis of Pattern $4 \mathrm{c}$ forms, in which the melodic $\mathrm{H}$ is realized only in combination with a $\mathrm{H}$-toned prefix, becomes quite opaque.

This section concludes with a discussion of the Remote Past Negative, a tense that has not been thoroughly studied, but whose collected data seem to have tonal differences compared to the corresponding affirmative forms and are noted here in the interest of full disclosure. Recall that in affirmative Remote Past 
forms, the $\mathrm{H}$ of the tense prefix á- doubles onto the stem-initial mora, e.g. $y$-aá[téex-aang-a] 'he was cooking'. In the examples in (83), which were elicited only once, there is almost no phonetic evidence that the $\mathrm{H}$ of the tense prefix extends onto the stem. ${ }^{21}$ The negative prefix sí- and the tense prefix á-are both realized $\mathrm{H}$, at the same pitch level. Unlike Remote Past affirmative forms, the steminitial mora is toneless in these negative forms. It is difficult to determine what underlies these surface patterns-if they are mistranscriptions or if the lack of spreading to the stem-initial mora is related to the deletion of one of the input moras (see fn. 21) or to the fact that the the negative prefix si- and the tense prefix $a-$, which surface at the same pitch level, form a binary $\mathrm{H}$ tone span. ${ }^{22}$

\begin{tabular}{|c|c|}
\hline ś́-y-áa[ly-a] tá [O] & 'eat' \\
\hline ś-y-á[shin-a] tá & 'dance' \\
\hline ś1-y-á[teex-a] tá & 'cook' \\
\hline śs-y-á[karaang-a] tá & 'fry' \\
\hline ś1-y-á[saambul-a] tá & 'de-roof' \\
\hline
\end{tabular}

The $\mathrm{V}$-initial stems in (84) surface with a level $\mathrm{H}$ tone span extending from the negative prefix sí- to the stem-initial mora. This is unexpected unless the $\mathrm{H}$ of the tense prefix $a$ - doubles onto the stem-initial mora.

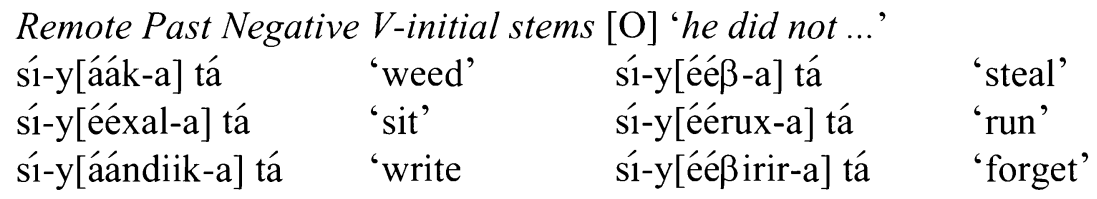

${ }^{21}$ There are a couple tokens of the root fuundix- 'knot' in the audio paradigm archive that sound like there is a stem-initial fall in Okumu's speech, which should be re-elicited along with the the likely anomalous monosyllabic stem forms, whose tense prefix has a long vowel. The other speaker, Wabala, produced these forms with the expected short vowel: sí-y-á[ly-a]tá 'he did not eat', sí-y-á[nyw-a] tá 'he did not drink'.

${ }^{22}$ The fact that the Hs of the negative prefix si- and the tense prefix $a$ - are realized at the same pitch level is potentially problematic for the Fusion analysis of (non-)downstep since there is no stem boundary between the two Hs. One could pursue the idea that there is a word boundary between the negative prefix and the subject prefix (making si- a proclitic) and allowing Fusion to apply across any domain boundary, i.e., stem, word, phrase, etc. Alternatively, a general version of Fusion or Default L Insertion could be ordered after the toneless mora of the subject marker $a$-is deleted, making the Hs of sí- and $a$-adjacent. 
The examples in (85) show the tonal effect of an object prefix. Like affirmative Remote Past forms, the melodic $\mathrm{H}$ surfaces on all moras of the steminitial syllable in combination with an object prefix. Like other Remote Past Negative forms, the negative prefix sí- and the tense prefix $a$ - surface $\mathrm{H}$, at the same pitch level. The melodic $\mathrm{H}$ and the $\mathrm{H}$ of the negative enclitic tá are also realized at the same pitch level when they are adjacent in monosyllabic stems.

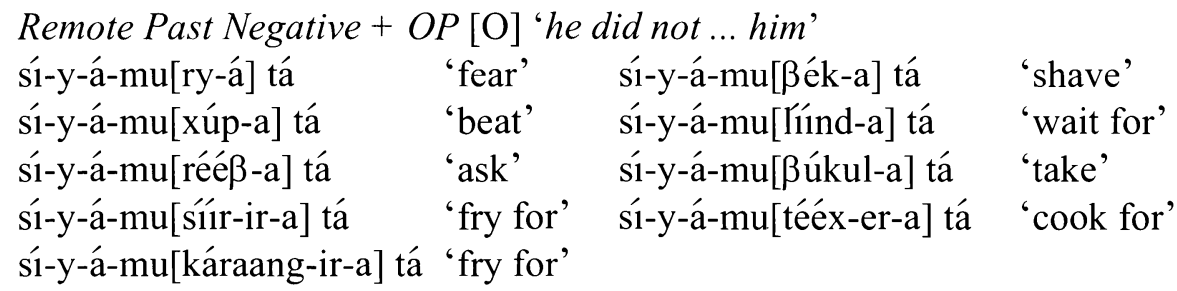

Data with V-initial stems and an object prefix are provided in (86). In all forms, a $\mathrm{H}$ extends from the negative prefix sí- to the tense prefix $a^{\prime}$-. There is variation in Okumu's pronunciations of the VCV stem in whether the stem $\mathrm{H}$ is realized as a rise or a downstepped level $\mathrm{H}$. On comparison with many other potential rising tones in Okumu's idiolect, e.g., Remote Past $y$-á-mw[ïr-a] 'he killed him', the form with rise is expected, but longer stems were produced with a downstepped level $\mathrm{H}$ on the derived long stem-initial syllable. ${ }^{23}$ It is possible that there is a phonological rule of Plateau, which eliminates a potential rise that is preceded by a $\mathrm{H}$ after Fusion or Default $\mathrm{L}$ Insertion has applied, i.e., H.ØH. $\rightarrow$ $\mathrm{H}^{\prime} \mathrm{HH}$. This rule may be optional, or it could also be that the "levelness" of the stem-initial $\mathrm{H}$ reflects a phonetic variant of phonological rise.

(86) Remote Past Negative + OP V-initial stems [O] 'he did not ... him'
ś-y-á-mw[ír-a] tá
$\sim$ ś-y-á!-mw[1́r-a] tá
sí-y-á'-mw[1'ímb-ir-a] tá
sí-y-á'-mw[áándiik-a] tá

Remote Past Negative forms with the reflexive prefix are provided in (87). Here we see that the negative prefix sí- and following mora (the underlying mora

${ }^{23}$ A similar case where a potential rising tone is realized as a downstepped level $\mathrm{H}$ after $\mathrm{H}$ is in Pattern 2a Present Negative forms with the $1 \mathrm{sg}$ object prefix $N$-, e.g., sí-y-áá[mbotóóxan-a] 'he is not going around me' (from intermediate sí-y-aá..., see (185) for additional examples). 
of tense prefix $a^{-}$) surface $\mathrm{H}$, at the same pitch level, and a level $\mathrm{H}$ surfaces on all moras of the stem-initial syllable, as in Remote Past affirmative forms.

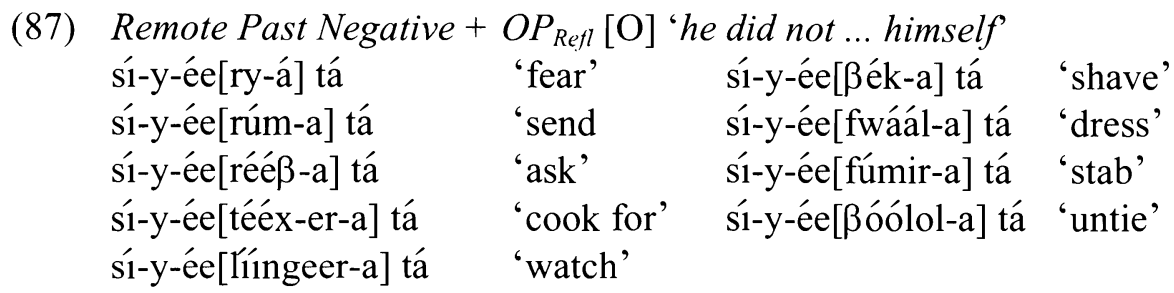

6.2 Pattern 4b. Pattern $4 \mathrm{~b}$ includes the tenses in (88), all of which take the final vowel suffix $-e$. Not all tenses with $-e$ have the Pattern $4 \mathrm{~b}$ melody, however, as the Remote Future is found in Pattern 1b. This section discusses the Subjunctive; data from the other Pattern $4 b$ tenses are provided in section 10.5 in the appendix.

(88) Pattern $4 b$ tenses

Crastinal Future Imperative $\quad$ Subjunctive

Pattern $4 \mathrm{~b}$ forms lacking an object prefix have the same stem tone patterns as in Pattern 2: the melodic $H$ surfaces on all moras of the initial syllable of monosyllabic (89a) and disyllabic (89b) stems and on all moras of the second syllable of trisyllabic and longer stems (89c), cf. Pattern 2a s-áa-li[fw-á] tá 'he

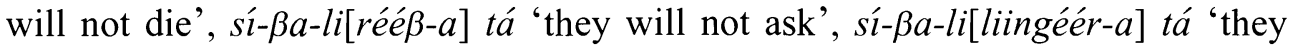
will not watch'.

(89) Subjunctive 'let's ...'
a. $x u[l y-e ́]$
'eat'
$\mathrm{xu}[$ tsy-é $]$
'go'
b. $x u[\beta$ ék-e]
'shave
$\mathrm{xu}$ [lól-e]
'look'
$\mathrm{xu}[\mathrm{réé} \beta-\mathrm{e}]$
'ask'
$\mathrm{xu}[$ tééx-e]
'cook'
c. xu[ßakál-e]
'set out'
$\mathrm{xu}[\beta u k u ́ l-e]$
'take'
$\mathrm{xu}$ [karááng-e]
'fry'
$\mathrm{xu}$ [fuundix-e]
'knot'
xu[fwiimbúl-e]
'uncover'
$\mathrm{xu}$ [liingéér-e]
'watch'
$\mathrm{xu}$ [lomálom-e]
'talk'
xu[xin-án-ir-e]
'dance for e.o.'
xu[teex-án-ir-e]
'cook for e.o.' 
VCV stems (90a) begin with a rise on the derived long vowel-the predictable combination of the toneless prefix vowel and the melodic $\mathrm{H}$ on the steminitial mora. In longer $\mathrm{V}$-initial stems $(90 \mathrm{~b})$, the melodic $\mathrm{H}$ surfaces on all moras of the second stem syllable.

(90) Subjunctive $V$-initial stems 'let's ...'
a. xw[aák-e] [O]
'weed'
xw[ímb-e] [O]
'sing'
b. xw[iirúx-e]
'run'
$\mathrm{xw}$ [aaníx-e]
'set out to dry'
$\mathrm{xw}$ [aandík-e] 'write'
xw[aasyáák-e]
'split wood'

The Pattern $4 \mathrm{~b}$ melodic $\mathrm{H}$ does not surface after the $\mathrm{H}$ of the object prefix, which doubles to the stem-initial mora, like the Pattern $4 \mathrm{a}$ tense prefix $a$-. The crucial data showing that the stem-initial $\mathrm{H}$ is not the melodic $\mathrm{H}$ are those in (91b), since the prefix $H$ does not extend to the second half of the stem-initial long syllable. These forms therefore contrast with those of Pattern 2, where the melodic $\mathrm{H}$ surfaces on the stem after the $\mathrm{H}$ of a prefix in disyllabic and longer

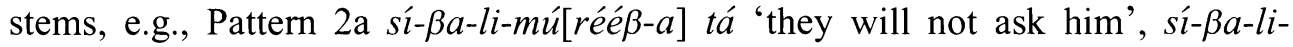
$m u ́[k a r a ́ a ́ n g-i r-a]$ tá 'they will not fry for him'.

(91) Subjunctive + OP 'let's ... him (mú) / them (ßá)'
a. xu-mú[ly-é]
'eat'
xu-mú[xw-é]
xu-mú[ßék-e]
'shave'
xu-mú[lól-e]
'pay dowry'
xu-mú[ßúkul-e]
'take'
xu-mú[léxer-e]
'see'
xu-ßá[léxuul-e]
'release'
xu-mú[káraang-ir-e]
'forgive'
'fry for'
xu-mú[ßóolol-e] 'untie'
xu-mú[l'ingeer-e] 'watch'
b. xu-mú[liind-e] 'wait for'
xu-mú[réeß-e]
'ask'
xu-mú[téex-er-e]
'cook for'
xu-mú[káangulul-e]
'untie'

The data in (92) show that all $\mathrm{V}$-initial stems have the same tonal pattern in combination with an object prefix: a level $\mathrm{H}$ tone surfaces on the derived long stem-initial syllable. 
(92) Subjunctive + OP V-initial stems 'let's ... him'

\begin{tabular}{|c|c|c|c|}
\hline xu-mw[áár-e] & 'operate or & xu-mw[1́1r-e] & 'kill' \\
\hline xu-mw[ímb-ir-e] & 'sing for' & xu-mw[ítsulir-e] & 'remember' \\
\hline xu-mw[1'1ßiirir-e] & 'forget' & xu-mw[áándiik-ir-e] & 'write for' \\
\hline xu-mw[áásyaak-ir-e] & 'split for' & & \\
\hline
\end{tabular}

In Pattern $4 \mathrm{~b}$ forms with the reflexive, the $\mathrm{H}$ of the reflexive is realized as a level $\mathrm{H}$ on the moras of the stem-initial syllable regardless of the number of syllables in the stem, and the melodic $\mathrm{H}$ is not realized on the stem. This differs importantly from Pattern 2a forms with a reflexive, where the reflexive $\mathrm{H}$ does not surface, e.g., si-y-ee[liingéér-aang- $a$ ] 'he is not watching himself'.

(93) Subjunctive $+O P_{\text {Refl }}$ 'let's ... ourselves'

\begin{tabular}{|c|c|c|}
\hline xw-ee[ry-é] [O] & 'fear' & xw-ee[ßék-e] \\
\hline $\mathrm{xw}-\mathrm{ee}[\mathrm{y}-1 \mathrm{r}-\mathrm{e}][\mathrm{O}]$ & 'kill' & [fúmir-e] $[\mathrm{O}]$ \\
\hline $\mathrm{N}$-ee[y-ímb-ir-e] [O] & 'sing for' & $x w-e$ \\
\hline $\mathrm{r}-\mathrm{e}][\mathrm{O}]$ & 'split for' & g-ire] \\
\hline$N$-ee & & $x w-e$ \\
\hline w-ee & ' untio & xw-ee[káángulul-e] \\
\hline
\end{tabular}

The present analysis posits distinct MHA rules for Pattern 2a and Pattern $4 \mathrm{~b}$ to capture the fact that the Pattern $2 \mathrm{a}$ melodic $\mathrm{H}$ is realized after a $\mathrm{H}$-toned prefix but the Pattern $4 \mathrm{~b}$ melodic $\mathrm{H}$ is not. Pattern $4 \mathrm{~b}$ is analyzed as having the same MHA rule as Pattern $4 a$, which requires a toneless mora before the target mora(s). The difference between Patterns $4 \mathrm{a}-\mathrm{b}$ is that Melodic H Shift, which shifts the melodic $\mathrm{H}$ to all moras of the following syllable in trisyllabic and longer stems, applies in Pattern 4b (and Pattern 2) but not in Pattern 4a.

In Pattern $4 \mathrm{~b}$ forms without an object prefix, the melodic $\mathrm{H}$ is assigned to the moras of the stem-initial syllable. In trisyllabic and longer stems (94b), the melodic $\mathrm{H}$ shifts from the moras of the stem-initial syllable to the moras of the following syllable. Melodic H Shift does not apply to shorter stems (94a) because the target moras must be followed by a syllable within the stem. 
(94) Pattern $4 b$

a. CVVCV stems: $\mathrm{xu}[\mathrm{ree} \beta-\mathrm{e}]$ 'let's ask'

$M H A: \sigma l / \mu$ _ $\quad M H S$

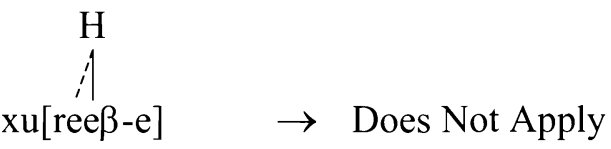

b. Trisyllabic and longer stems: xu[lomálom-e] 'let's talk' MHA: $\sigma 1 / \mu$ _ $\quad M H S$

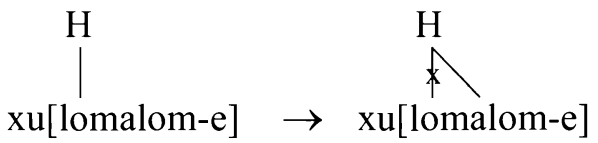

Melodic H Assignment fails to apply to Pattern 4b forms with an object prefix because the moras of the stem-initial syllable immediately follow the $\mathrm{H}$ of the object prefix. Since the moras of the first and second syllables of the stem are free, Doubling subsequently spreads the $\mathrm{H}$ of the object prefix to the stem-initial mora. The level $\mathrm{H}$ tone that surfaces on the derived long stem-initial syllable in $\mathrm{V}$-initial stems with an object prefix is the result of Doubling: (after MHA) $x u$ $m u ́[a r-e] \rightarrow$ (Doubling) $x u-m u ́[a ́ r-e] \rightarrow$ (Hiatus Resolution) $x u-m w[a ́ a ́ r-e]$.

(95) Pattern 4b+OP: xu-mú[téex-er-e] 'let's cook for him'

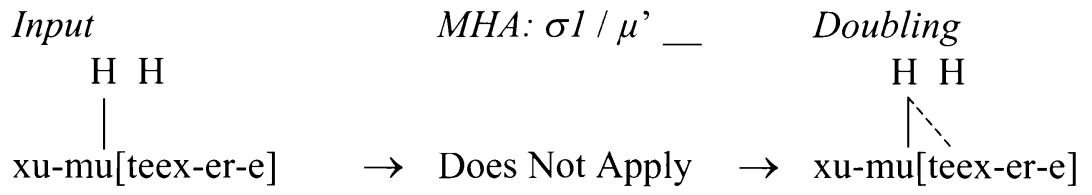

The derivation in (96) shows the analysis of Pattern $4 \mathrm{~b}$ forms with the reflexive. Since OHA: $\sigma 1$ is ordered before MHA: $\sigma 1 / \mu$ ' is assigned to the moras of the stem-initial syllable, and the melodic $\mathrm{H}$ cannot be assigned to the stem. Melodic $\mathrm{H}$ Shift applies only to the melodic $\mathrm{H}$, so the $\mathrm{H}$ of the reflexive remains on the moras of the stem-initial syllable.

(96) Pattern $4 b+O P_{\text {Refl }}$ : xw-ee[ßóólol-e] 'let's untie ourselves'
$O H A: \sigma l$
$M H A \& M H S$
Hiatus Resolution
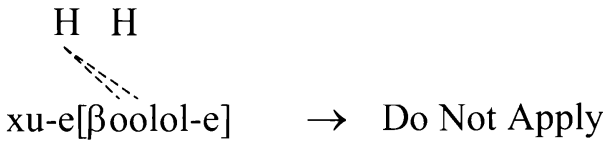
$\mathrm{H} \mathrm{H}$

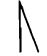
$\rightarrow$ xw-ee[ßoolol-e] 
6.3 Pattern 4c. Pattern $4 c$ is found in the tenses in (97). Like the Pattern 2 tenses, the Pattern $4 c$ tenses are all negatives-in this case, the negative counterparts of Pattern 3 tenses. Although there is a morphological relationship between Pattern 3 and Pattern 4c, there is no evidence for a tonal relationship between the

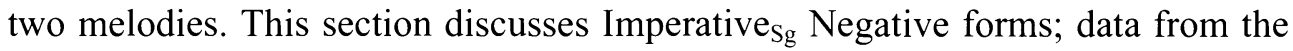
other tenses are found in section 10.6 in the appendix.

(97) Pattern 4c tenses

Hesternal Perfective Negative [O] Hodiernal Perfective Negative Imperative $_{S g}$ Negative

Pattern $4 \mathrm{c}$ is unique among the Tura tone melodies in that its melodic $\mathrm{H}$ fails to surface in forms that lack an object prefix (and unlike Pattern 4a there is no $\mathrm{H}$-toned tense prefix), as shown by the examples in (98)-(99). The only $\mathrm{H}$ in these examples is on the negative marker tá.

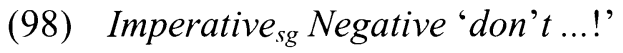

$\begin{array}{llll}\text { o-la[ly-a] tá } & \text { 'eat' } & \text { o-la[nyw-a] tá } & \text { 'drink' } \\ \text { o-la[kon-a] tá } & \text { 'sleep' } & \text { o-la[xin-a] tá } & \text { 'dance' } \\ \text { o-la[ree } \beta-a] \text { tá } & \text { 'ask' } & \text { o-la[teex-a] tá } & \text { 'cook' } \\ \text { o-la[ßukul-a] tá } & \text { 'take' } & \text { o-la[karaang-a] tá } & \text { 'fry' } \\ \text { o-la[fuundix-a] tá } & \text { 'knot' } & \text { o-la[liingeer-a] tá } & \text { 'watch' }\end{array}$

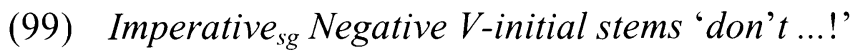

$\begin{array}{llll}\text { o-l[eemb-a] tá } & \text { 'sing' } & \text { o-l[eey-a] tá } & \text { 'sweep' } \\ \text { o-l[eerux-a] tá } & \text { 'run' } & 0-1[\text { aandiik-a] tá } & \text { 'write' }\end{array}$

The presence of an object prefix reveals the Pattern 4c melodic $\mathrm{H}$ : the melodic $\mathrm{H}$ is realized on all moras of the initial syllable of disyllabic stems (100b) and on all moras of the second syllable of trisyllabic and longer stems (100c). As we have seen in Pattern 2 and Pattern 4b, the melodic $\mathrm{H}$ is not realized after the $\mathrm{H}$ of the object prefix in monosyllabic stems (100a). 


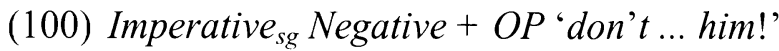

a. o-la-mú[ry-a] tá 'fear'

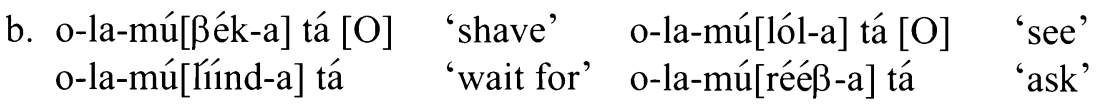

c. o-la-mú[ßßoolól-a] tá 'untie' o-la-mú[teex-ér-a] tá 'cook for' o-la-mú[rekéres-y-a] tá 'listen to' o-la-mú[karááng-ir-a] tá 'fry for' o-la-mú[kaangúlul-a] tá 'untie'

VCV stems (101a) are realized with a level $\mathrm{H}$ on the moras of the derived long stem-initial syllable-the predictable combination of V́ $+\hat{V}$. Longer V-initial stems (101b) have a fall on the derived long stem-initial syllable (the $\mathrm{H}$ of the object prefix plus the toneless stem-initial mora), followed by the melodic $\mathrm{H}$ on all moras of the second syllable of the stem.

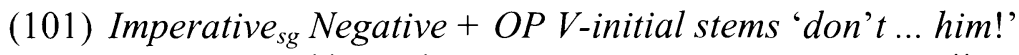

a. o-la-mw[áár-a] tá 'operate on' o-la-mw[ír-a] tá 'kill'

b. o-la-mw[irimb-ír-a] tá 'sing for' o-la-m[úulır-a] tá 'listen to' o-la-mw[áandúḱ-ir-a] tá 'write for'

Pattern $4 \mathrm{c}$ forms with the reflexive differ tonally from other Pattern $4 \mathrm{c}$ forms. Irrespective of the number of syllables in the stem, the reflexive $\mathrm{H}$ surfaces on all moras of the stem-initial syllable. These forms are therefore identical to other Pattern 4 reflexive forms, where the $\mathrm{H}$ of the reflexive surfaces on the moras of the stem-initial syllable, not the melodic $\mathrm{H}$.

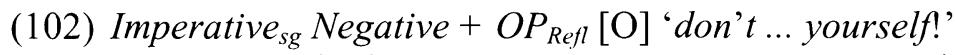

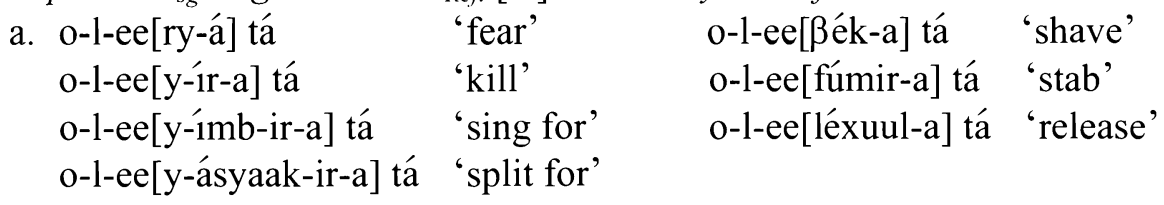
b. o-1-ee[fwáál-a] tá
'dress'
o-l-ee[réé $\beta-a]$ tá 'ask'
o-l-ee[ßóólol-a] tá
'untie'
o-l-ee[fúúnix-a] tá 'cover'
o-l-ee[língeer-a] tá
'watch' 
Pattern $4 \mathrm{c}$ is similar to Pattern $4 \mathrm{~b}$ in that its melodic $\mathrm{H}$ surfaces on the first or second stem syllable, depending on the tone of the prefix immediately preceding the stem. In Pattern $4 b$, the melodic $\mathrm{H}$ surfaces only when the pre-stem mora is toneless. In Pattern 4c, the melodic $\mathrm{H}$ surfaces only when the pre-stem mora is $\mathrm{H}$. This generalization is formalized by a distinct rule of Melodic $\mathrm{H}$ Assignment, MHA: $\sigma 1 / \mathrm{H}_{\text {_ }}$, which assigns the melodic $\mathrm{H}$ to the moras of the stem-initial syllable when the preceding mora is $\mathrm{H}$.

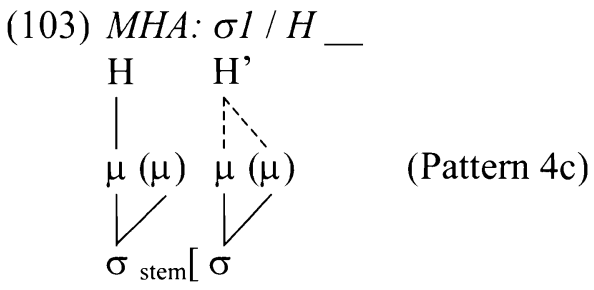

The derivation in (104) shows that the melodic $\mathrm{H}$ fails to be assigned to the stem in Pattern $4 \mathrm{c}$ forms lacking an object prefix because the mora immediately preceding the stem is toneless.

(104) Pattern 4c: o-la[liingeer-a] tá 'don't watch!'

Input

MHA: $\sigma l / H$

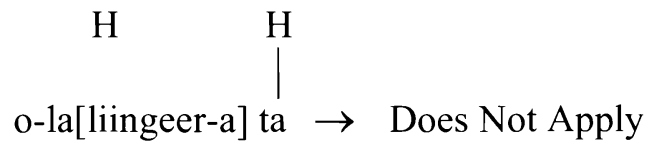

When there is an object prefix, the melodic $\mathrm{H}$ is assigned to the moras of the stem-initial syllable. In trisyllabic and longer stems, the melodic $\mathrm{H}$ shifts to the moras of the second syllable of the stem by Melodic H Shift. The melodic $\mathrm{H}$ fails to surface in monosyllabic stems like o-la-mú[ry-a] tá 'don't fear him!' because $\mathrm{H}[\mathrm{H}]$ Deletion deletes the melodic $\mathrm{H}$ from a monosyllabic stem after a $\mathrm{H}$ toned prefix.

(105) Pattern 4c + OP: o-la-mú[teex-ér-a] tá 'don't cook for him!'

MHA: $\sigma 1 / H$ MHS

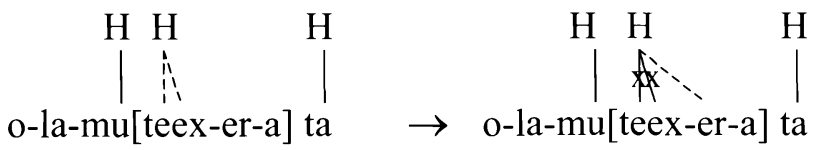


As in Pattern $4 a-b$, the $\mathrm{H}$ of the reflexive is assigned to the moras of the stem-initial syllable before Pattern 4c MHA. This blocks the melodic $\mathrm{H}$ from being assigned, and since Melodic $\mathrm{H}$ Shift applies only to melodic $\mathrm{Hs}$, the $\mathrm{H}$ of the reflexive surfaces on the moras of the stem-initial syllable.

(106) Pattern $4 c+O P_{\text {Refl: }}$ o-l-ee[tééx-er-a] tá 'don't cook for yourself' $O H A$ $M H A \& M H S$

Hiatus Resolution
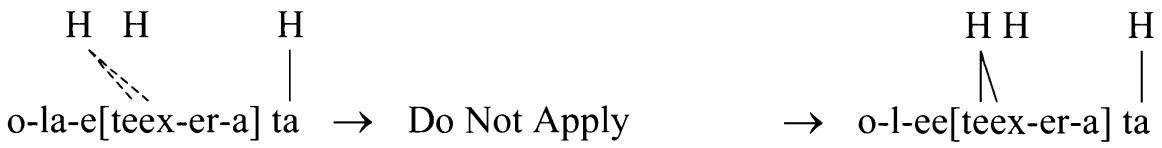

\section{Summary.}

The preceding sections have analyzed the Tura verbal tone system with the rules in (107).

(107) Tura tonal rules

MHA: Final

links the melodic $\mathrm{H}$ to the stem-final mora (Pattern 1).

MHA: Final II

links the melodic $\mathrm{H}$ to the stem-final mora (Pattern 3).

MHA: $\sigma 1$

links the melodic $\mathrm{H}$ to all moras of the stem-initial

MHA: $\sigma 1 / \mu^{\prime}$ syllable (Pattern 2).

links the melodic $\mathrm{H}$ to all moras of the stem-initial syllable, provided that the pre-stem mora and the moras of the first two stem syllables are toneless (Patterns 4a-b).

MHA: $\sigma 1 / \mathrm{H}_{-}$ links the melodic $\mathrm{H}$ to all moras of the stem-initial syllable, provided that the pre-stem mora is $\mathrm{H}$, and the moras of the first two stem syllables are toneless (Pattern 4c).

OHA: $\sigma 1$ links the floating $\mathrm{H}$ of an object prefix or reflexive to all moras of the stem-initial syllable, provided that the moras of the first two syllables of the stem are toneless.

Minimal Spread spreads the melodic $\mathrm{H}$ to all moras of the preceding syllable. 
Unbounded Spread iteratively spreads the melodic H leftward across the stem, but not into the stem-initial syllable.

Melodic H Shift

shifts the melodic $\mathrm{H}$ from the moras of the steminitial syllable to the moras of the following syllable, as long as the syllable of the target moras is not final (Pattern 2, 4b-c).

Meeussen's Rule deletes $\mathrm{H}$ after $\mathrm{H}$.

Doubling spreads $\mathrm{H}$ from the pre-stem mora to the stem-initial mora, provided that the moras of the first two syllables of the stem are toneless.

$\mathrm{H}[\mathrm{H}]$ Deletion

Fusion deletes $\mathrm{H}$ from a monosyllabic stem after $\mathrm{H}$. fuses $\mathrm{H}$ on a monosyllabic stem with the preceding $\mathrm{H}$ (Pattern 1).

Wd-Initial Delinking delinks the $\mathrm{H}$ of an object prefix in word-initial position.

Pre-H Delinking renders $(C V ́ V))_{\mathrm{H}}(C V)_{\mathrm{H}}$ into $C V ́ V C V ́$.

$[\mathrm{H}-\mathrm{H}]_{\sigma}$ Delinking delinks the left branch of a multiply linked $\mathrm{H}$ that is preceded by $\mathrm{H}$ within the same syllable

These rules include several rules of Melodic $\mathrm{H}$ Assignment, whose formulation and ordering with respect to other tone rules account for the differences among the many tonal patterns in the surface position of the melodic $\mathrm{H}$ and in the complex interactions of melodic $\mathrm{Hs}$ with $\mathrm{H}$-toned prefixes. The ordering relationships between the various MHA rules, OHA, and Doubling, are summarized in (108).

\section{(108) Order of MHA rules with respect to OHA and Doubling \\ Pattern 1 MHA, Pattern 2 MHA > OHA > Pattern 3 MHA, \\ Pattern 4a-b MHA, Pattern 4c MHA > Doubling}

Two rules of MHA are posited that link the melodic $\mathrm{H}$ to the stem-final mora-one for Pattern 1 and one for Pattern 3-due to several differences between these melodies. The Pattern 1 melodic $\mathrm{H}$ is subject to leftward spreading: Pattern 1a $\beta a$-li[teex-ér-án-á] 'they will cook for e.o.', but the Pattern 3 melodic $\mathrm{H}$ is not: Pattern 3a a[fuunduluul-é] 'he unknotted'. The Pattern 1 melodic H blocks Doubling of a $\mathrm{H}$-toned prefix onto the stem-initial mora and assignment of the $\mathrm{H}$ of the reflexive onto the moras of the stem-initial syllable: $a$-li-mú[liingéér-á] 'he will watch him', a-ly-ee[kaangúlúl-á] 'he will untie himself', but the Pattern 3 melodic $\mathrm{H}$ does not: a-ßá[liningeer-eré] 'he watched them', y-ee[káánguluul-é] 
'he untied himself'. These differences emerge in the present analysis because Pattern 1 MHA and leftward spreading apply before Doubling and assignment of the reflexive $\mathrm{H}$ to the stem (via OHA), which apply before Pattern $3 \mathrm{MHA}$. Doubling and OHA are blocked by the Pattern 1 melodic $\mathrm{H}$, which has spread left across the stem, but are not blocked by the Pattern 3 melodic $\mathrm{H}$, which has not yet been assigned to the stem.

Three additional MHA rules-one for Pattern 2, one for Pattern 4a-b, and one for Pattern $4 \mathrm{c}$-are posited to account for several tonal differences among the melodic Hs that surface on one of the first two syllables of the stem. These rules all assign the melodic $\mathrm{H}$ to the moras of the stem-initial syllable but differ in their sensitivity to the presence of a tone on the pre-stem mora and in whether Melodic $\mathrm{H}$ Shift subsequently applies. Pattern $2 \mathrm{MHA}$ is insensitive to the presence or absence of tone on the mora immediately preceding the stem; the Pattern 2 melodic $\mathrm{H}$ surfaces (on the moras of the second syllable of trisyllabic and longer stems) whether or not there is a H-toned prefix: Pattern 2a sí- $\beta a$-li[liingéér-a] tá 'they will not watch', sí- $\beta a-l i-m u ́[$ liingéér-a] tá 'they will not watch him'. Pattern $4 \mathrm{a}-\mathrm{b}$ MHA requires the mora immediately preceding the stem to be toneless: the Pattern 4a-b melodic $\mathrm{H}$ does not surface when the pre-stem mora is H: Pattern 4a $y$ á-mu[língeer-a] 'he watched him' (the pre-stem $\mathrm{H}$ is first deleted by Meeussen's Rule), cf. $\beta$-aá [téex-an-ir-a] 'they cooked for e.o.' (MHA is blocked, so the H of the tense prefix doubles to the stem-initial mora); Pattern $4 \mathrm{~b} x u$ [teex-án-ir-e] 'let's cook for e.o.', cf. xu-mú[káangulul-e] 'let's untie him' (MHA is blocked, so the $\mathrm{H}$ of the object prefix doubles to the stem-initial mora). Pattern 4c MHA requires the mora immediately preceding the stem to be H-toned, since the melodic $\mathrm{H}$ does not surface otherwise: o-la-mú[kaangúlul-a] tá 'don't untie him!', cf. ola[liingeer-a] tá 'don't watch!'. The final surface position of the melodic $\mathrm{H}$ in Patterns 2, 4b, and 4c is achieved by Melodic $\mathrm{H}$ Shift, which shifts the melodic $\mathrm{H}$ to the moras of the second syllable of trisyllabic and longer stems.

Further tonal differences among these melodies are also derived by the distinct " $\sigma 1$ " MHA rules and their ordering with respect to Doubling and OHA. Pattern 2 MHA is ordered before both Doubling and OHA. Since Doubling and OHA both require the moras of the first two stem syllables to be free, neither rule applies in Pattern 2: sí- $\beta a$-li-mú[liingéér-a] tá 'they will not watch him', sí-yee[ $\beta$ oolól-aang- $a]$ 'he is not untying himself'. Since OHA precedes the Pattern 4 MHA rules and the MHA rules require the target moras to be free, the reflexive $\mathrm{H}$ surfaces on the moras of the stem-initial syllable in all three melodies, blocking the subsequent assignment of the melodic H: 4a y-ée[tééx-er-a] 'he cooked for himself', 4b xw-ee[káángulul-e] 'let's untie ourselves', 4c o-l-ee[língeer-a] tá 
'don't watch yourself!'. The H of the reflexive remains on the moras of the steminitial syllable since only melodic Hs are subject to Melodic H Shift. Doubling follows all three Pattern 4 MHA rules but applies in Patterns $4 \mathrm{a}-\mathrm{b}$ because the moras of the first two stem syllables are free, since the $\mathrm{H}$ of the prefix prevents the melodic $\mathrm{H}$ from being assigned to the stem (Pattern 4a-b MHA requires a preceding toneless mora): 4a $\beta$-aá[téex-an-ir-a] 'they cooked for e.o.', 4b xumú[káangulul-e] 'let's untie him'. Since the melodic H surfaces in Pattern 4c after an object prefix (MHA requires a preceding $\mathrm{H}$ ) and Doubling follows MHA, Doubling is blocked: $o$-la-mú [kaangúlul-a] tá 'don't untie him!'

Given the ordering in (108), it is challenging to account for the fact that the melodic $\mathrm{H}$ fails to be realized on a monosyllabic stem after $\mathrm{H}$ in Pattern 2 and Pattern $4 \mathrm{c}$ but is realized on a monosyllabic stem after $\mathrm{H}$ in Pattern 1 (see (16)(17) above). The facts of reflexive $\mathrm{H}$ assignment require Pattern 1 MHA to precede Pattern 4c MHA, so a rule of Fusion is ordered after Pattern 1 MHA and before all other MHA rules. Since there is no Doubling in contexts where $\mathrm{H}[\mathrm{H}] \mathrm{De}-$ letion has applied, Doubling must be ordered before $\mathrm{H}[\mathrm{H}]$ Deletion. $^{24}$

The fact that the leftward spreading rules (Minimal Spread and Unbounded Spread) apply only in Pattern 1 can be accounted for by ordering the spreading rules before all of the other MHA rules. On the other hand, it is not easy to account for the fact that Melodic H Shift appies in Patterns 2a, 4b, and 4c but not in Pattern 4a since Patterns 4a-b are derived using the same MHA rule. It would be possible to make Melodic $\mathrm{H}$ Shift a general rule if Patterns $4 \mathrm{a}$ and $4 \mathrm{~b}$ were given distinct MHA rules. Under this approach, Pattern 4a MHA would follow Melodic $\mathrm{H}$ Shift, and Pattern 2, 4b, and 4c MHA rules would precede Melodic H Shift. Concerning the fact that Melodic $\mathrm{H}$ Shift not apply to the $\mathrm{H}$ of the reflexive or an object prefix, it is difficult to find a solution within the present framework that does not require reference to the morphological source of the floating Hs, since Pattern 2 MHA precedes OHA, and Pattern $4 \mathrm{~b}$ and Pattern 4c MHA rules follow, yet all these melodic Hs shift.

${ }^{24}$ Another possibility would be to reformulate the MHA rules, but it is challenging to derive the "H[H]" effects from a positive condition on MHA since the required condition would be a disjunction: MHA applies if the pre-stem mora is toneless or if a mora follows the syllable of the target moras. This could be formalized as a negative output constraint, ${ }^{*} \mathrm{H}[\mathrm{H}]$, which would block the application of all MHA rules but Pattern 1, but this would be inconsistent with the formulation of the other conditional rules in this analysis. 


\section{Variation.}

This final section discusses variation between the two speakers of Tura who were consulted as part of this project: Kenneth Okumu and Jonathon Wabala. ${ }^{25}$ The data presented above reflect, for the most part, the speech of both consultants, but there are a number of cases where the speakers' tonal patterns differ. In cases of divergence, the data presented above reflect Okumu's idiolect. Okumu's data are the primary source of data for this article for several reasons. First, the database of forms collected from Okumu is more complete. Second, there is very little phonological variation in the data collected from Okumu, while Wabala has multiple tonal patterns in several contexts. Okumu has lived his entire life in Butura, while Wabala has lived for some time outside of this region, so it is more likely that Okumu's variety would be found among other Tura speakers in Butura. Finally, Wabala's pronunciations are somewhat more phonetically ambiguous than Okumu's and are more difficult to transcribe and analyze.

Despite these difficulties of the data collected from Wabala, the collected data are discussed here in some detail for a number of reasons. As noted in section 1 , one of the most striking features of Luyia tonology is the diversity among the dialects-no two dialects have been found to have the same tonal system, and even very closely related systems, e.g., Tura and Khayo (Marlo, to appear), have interesting differences. Therefore, to appreciate the full extent of tonal differences among Luyia varieties, it is important to consider variation among speakers of the same dialect. Moreover, within the I-language perspective of generative linguistics (see Isac \& Reiss 2008 and references therein), the object of inquiry is the internal, intensional tonology of individual speakers, and thus it is irrelevant for the construction of theories of tonal rules and representations whether Wabala's tonal grammar is identical to the E-language notions "Tura", "Khayo", etc. Additionally, the data are provided and discussed in the interest of full disclosure,

${ }^{25}$ Okumu is a male in his 30 s residing on his family's traditional homestead near the stage called Works between the towns of Nambale and Mayoni on the Busia-Mumias road in the Western Province of Kenya. Wabala is a male in his 50s who has lived in the town of Busia, Kenya for at least fifteen years. Both speakers were interviewed in Busia, a busy town on the Kenya-Uganda border with an urban population of 30,777, according to the 1999 Kenyan census. Busia has a mixed Luyia-Luo (Nilotic) population and small numbers of speakers of other languages including Teso (Nilotic), Gusii (Bantu), and Kikuyu (Bantu). The predominant Luyia group in Busia is Khayo, although there are also substantial Saamia and NyalaWest populations, and speakers of nearly all Luyia dialects can be found there. 
like the Remote Past Negative examples discussed above that are not fully understood, as an indication of future work that should be conducted on the dialect.

To preview the results of the following subsections, we can note that there is a morphological difference between the two speakers in the tonal melody of the Hesternal Perfective Negative tense (section 8.1); Wabala generally renders potential rising tones into level $\mathrm{H}$ (section 8.2); there are anomalies in the process of Doubling in Wabala's idiolect (section 8.3); adjacent derived Hs have a different phonetic output with respect to downstep in Wabala's idiolects, suggesting a different formulation of Pattern 2 and 4c rules of MHA (section 8.4); the rules of leftward spread that apply in Pattern 1 have a different formultation in Wabala's idiolect (section 8.5); and the $\mathrm{H}$ of the reflexive is realized differently in Wabala's idiolect (section 8.6).

Some aspects of Wabala's tonal grammar appear to reflect an influence from the Khayo dialect. The Luyia-speaking area-one of the most densely populated rural regions in the world in which children and adults are exposed to a complex array of different linguistic systems - constitutes a rich area for studies of language variation, change, code-switching, etc. To my knowledge, there has been virtually no research in these areas within Luyia, probably due to the lack of foundational materials describing the many linguistic varieties found in the region. This section represents a first attempt at capturing in an explicit way the tonal differences among speakers from the same Luyia speech community.

8.1 Morphological differences. A morphological difference between the two speakers is the tonal melody of the Hesternal Perfective Negative. This tense has the Pattern 4c melody in Okumu's idiolect, like the Hodiernal Perfective Negative

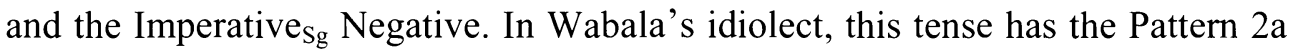
melody, like the Indefinite Future Negative and the Present Negative. The two speakers also differ in whether the tense prefix $a$ - surfaces as a short vowel (Okumu) or as a long vowel (Wabala); see fn. 20. Wabala's treatment of this tense can be understood in terms of the Pattern 1-2 affirmative-negative pairs, since the Hesternal Perfective affirmative has the Pattern la melody, like the affirmative forms of the Indefinite Future and Present. Okumu's classification of this tense may reflect a partial neutralization with the Hodiernal Perfective Negative, since both are negatives that take the perfective suffix -ire, although the surface forms should still be distinguishable, since the Hodiernal Perfective Negative lacks a tense prefix, while the Hesternal Perfective takes $a$-. 
8.2 Rise Elimination. A consistent difference between the two speakers is that Wabala renders potential rising tones into level $\mathrm{H}$ by the rule of syllable-internal spreading in (109).

(109) Rise Elimination [W]

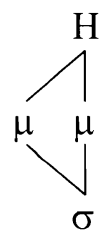

Rise Elimilation applies to the VCV stems in Pattern 1a in (110) and Pattern 2a in (111), cf. $a$-l[ímb-á] [O] 'he will sing', sí- $\beta a-l[$ iı́mb-a] tá [O] 'they will not sing'.

(110) Pattern 1a: Indefinite Future VCV stems [W] 'he will ...'
a-1[11́mb-á]
'sing'
a-1[1́ts-á]
'come'

(111) Pattern 2a: Indefinite Future Negative VCV stems [W] 'he will not ...'

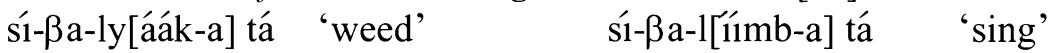

A second case where Rise Elimination applies is the disyllabic V-initial stems in Pattern 4b, as shown in the examples in (112). Okumu has a rising tone in the same context, e.g., $x w[a a ́ k-e]$ 'let's weed'.

(112) Pattern 4b: Subjunctive VCV stems [W] 'let's ...'

$\mathrm{xw}$ [áák-e]

'weed'

$\mathrm{xw}[11 \mathrm{mmb}-\mathrm{e}]$

'sing'

It appears that not all potential rising tones are leveled out to $\mathrm{H}$ in Wabala's idiolect. The examples in (113) in Pattern 3b are transcribed with a stem-initial rise, just as in Okumu's forms in (69).

(113) Pattern 3b: Imperative sg $_{\text {I }}+$ OP V-initial stems [W] '... him!'

$\begin{array}{llll}\operatorname{mw}[\text { aá!r-é] } & \text { 'operate on' } & \operatorname{mw}[\text { [ír-é] } & \text { 'kill' } \\ \operatorname{mw}[\text { ímmb-ir-é] } & \text { 'sing for' } & \operatorname{mw}[\text { aándiik-ir-é] } & \text { 'write for' }\end{array}$

A few other cases where the potential rise is in word-initial position are phonetically ambiguous between level $\mathrm{H}$ and rise. This is particularly true when the word-initial segment is a glide, as in the examples in (114)-(115), which are tran- 
scribed essentially just like Okumu's forms in (74)-(75). This suggests that the lack of Rise Elimination in these forms may be a phonetic effect, owing to the phrase-initial position of the rise, although it is not clear why there seems to be a phonetic contrast between the forms in (112)-(113).

(114) Pattern 4a: Remote Past [W] 'he (y-)/ they $(\beta-)$...ed'

\begin{tabular}{|c|c|c|c|}
\hline y-aá[fw-á] & 'die' & y-aá[tsy-á] & 'go' \\
\hline y-aá[ßék-a] & 'shave' & y-aá[xín-a] & 'dance' \\
\hline y-aá[téex-a] & 'cook' & y-aá[xéeng-a] & 'cut' \\
\hline y-aá[ßákal-a] & 'set out' & y-aá[ßúkul-a] & 'take' \\
\hline y-aá[káraang-a] & 'fry' & y-aá[léxuul-a] & 'release' \\
\hline y-aá[fúundix-a] & 'knot' & y-aá[sáakuul-a] & 'destroy the roof' \\
\hline y-aá[lómalom-a] & 'talk' & y-aá[sáambuul-a] & 'de-roof' \\
\hline$\beta$-aá[téex-an-ir-a] & 'cook for e.o.' & y-aá[fúundix-aang-a] & 'knot' \\
\hline
\end{tabular}

(115) Pattern 4a: Remote Past V-initial stems [W] 'he ...ed'

$\begin{array}{llll}\text { y[aák-a] } & \text { 'weed' } & \text { y[émb-a] } & \text { 'sing' } \\ \text { y[aánix-a] } & \text { 'set out to dry' y[érux-a] } & \text { 'run' } \\ \text { y[aándiik-a] } & \text { 'write' } & y[\text { aásyaak-a] } & \text { 'split wood' }\end{array}$

The examples in (116)-(117) from Pattern 2b and Pattern 4a also show a potential rise that is realized as a level $\mathrm{H}$, cf. sí-y-a-xá-mw[ïr-a]tá 'he did not just kill him' [O], $y-a-m w$ [iır $-a]$ [O] 'he killed him'. In each of these cases, the $\mathrm{H}$ that is leveled out follows a H-toned tense prefix and is downstepped, like the anomalous Remote Past Negative examples in Okumu's idiolect in (86), e.g., sí-

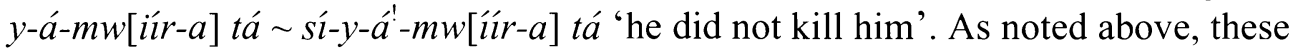
forms may reflect a phonological rule of Plateau or phonetic leveling of rise after H. Differences in the patterns of downstep between the two speakers are discussed below in section 8.4.

(116) Pattern 2b: Imm. Past Neg. + OP VCV stems [W] 'he did not just ... him' sí-y-a-xá'-mw[áár-a] tá 'operate on' sí-y-a-xá!-mw[11́r-a] tá 'kill'

(117) Pattern 4a: Remote Past + OP V-initial stems [W] 'he ...ed him' y-á-'mw[áár-a] 'operate on' y-á-'mw['ír-a] 'kill' y-á-'mw[11mb-ir-a] 'sing for' y-á-'mw[11xas-y-a] 'make sit' y-á-'mw[áándiik-ir-a] 'write for' $\quad \mathrm{y}$-á-'mw[áásyaak-ir-a] 'split wood f.' 
8.3 Doubling. The process of Doubling described above, which spreads the $\mathrm{H}$ of a prefix one mora to the right to the stem-initial mora, is phonologically and phonetically ambiguous in Wabala's idiolect. There are cases where the rule appears to apply where it should not and others where it does not apply where it should or where it appears to apply, but in a phonetically gradient way.

In the Pattern $2 b$ Immediate Past Negative, there is phonetic variation in the rightward extent of the $\mathrm{H}$ of the tense prefix $x a ́$ - in Wabala's pronunciations, although this variation is not reflected in the transcriptions (see (48) above). In several examples, the $\mathrm{H}$ of the tense prefix appears to extend onto the following object prefix, e.g., sí-y-a-xá-mú[lexúúl-a] tá 'he did not just release him', sí-y-axá-múl $[$ réé $\beta-a]$ tá 'he did not just ask him', which is clearly toneless in Okumu's pronunciations. ${ }^{26}$ Wabala's pronunciations could possibly represent a more general application of Doubling applying after the deletion of the $\mathrm{H}$ of the object prefix, but there is no other evidence for a more general process of Doubling in Wabala's tonal grammar.

Wabala also has phonetic variation in cases where Doubling is expected to apply such as Pattern 4b forms with an object prefix, e.g., xu-mú[ßék-e] 'let's shave him' and xu-mú[rée $\beta-e]$ 'let's ask him' (see (91) above). In many of Wabala's recorded tokens of examples of this type, the stem-initial mora is realized clearly with high pitch, as transcribed. However, in other cases, the pitch of the stem-initial mora appears to be on a trajectory to the following L, suggesting that the stem-initial mora is not $\mathrm{H}$ or that Doubling is phonetically gradient. Furthermore, Wabala pronounced all of the Pattern $4 \mathrm{~b}$ examples with a $\mathrm{V}$-initial stem in (92) above at least one time with a level H. However, there are a few examples in the recording archive, given in (118), with a clear falling tone, providing further evidence for the variability of Doubling in Wabala's idiolect.

Pattern 4b: Subjunctive + OP V-Initial [W] 'let's ... him'
$\begin{aligned} & \text { xu-mw[áar-e] } \\ & \text { xu-mw[1imb-ir-e] }\end{aligned}$ 'sing for'

\footnotetext{
${ }^{26}$ Several of Wabala's examples in the first recording of Immediate Past Negative forms in the Tura audio paradigm archive are likely from a tense that was not otherwise documented in Tura, the Recent Past (Marlo 2007), which has the toneless tense prefix $x a$ - and the Pattern 1 melodic $\mathrm{H}$. Additionally, due to low amplitude in the recorded examples, it is not possible to provide with complete confidence a transcription of Wabala's monosyllabic stems, though the recorded examples seem to lack a melodic $\mathrm{H}$, as we would otherwise expect.
} 
8.4 Downstep. As described above, Okumu realizes the melodic $\mathrm{H}$ on the stem-initial syllable at the same pitch level as an immediately preceding $\mathrm{H}$-toned prefix (see (19) above for a summary of contexts and discussion). As shown by the data in (119), which are representative of both speakers, the melodic $\mathrm{H}$ on the moras of the stem-initial syllable is also realized at the same pitch level as the preceding $\mathrm{H}$ in Pattern 1, irrespective of the length of the stem-initial syllable.

(119) Melodic H and H-toned prefix realized at the same pitch level

Pattern 1a +OP (Indefinite Future, 'he will ... him')

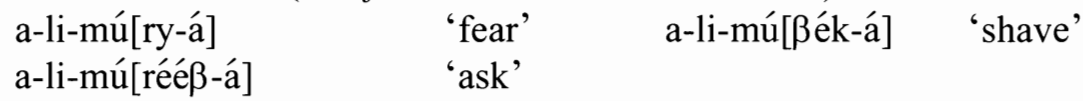

Pattern $1 b$ (Near Future, 'he will ...')

$\begin{array}{lll}\text { a-lá[fw-á] } & \text { 'die' } & \text { a-lá[ßék-á] } \\ \text { a-lá[téex-á] } & \text { 'cook' } & \end{array}$

However, as shown in (120)-(122), the melodic $\mathrm{H}$ on the stem-initial is downstepped in CVCV stems and optionally downstepped in CVVCV stems in Pattern $2 \mathrm{a}-\mathrm{b}$ and Pattern $4 \mathrm{c}-$ Patterns in which the melodic $\mathrm{H}$ is realized on the moras of the second syllable of trisyllabic and longer stems.

(120) Pattern 2a: Indefinite Future Negative $+O P[W]$ 'they will not ... him'

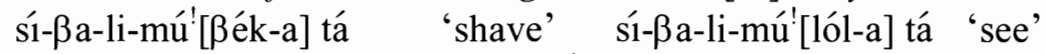

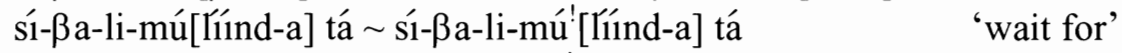

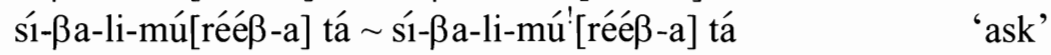

(121) Pattern 2b: Immediate Past Negative [W] 'he did not just ...'

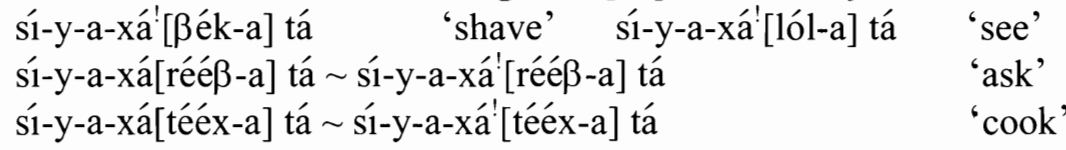

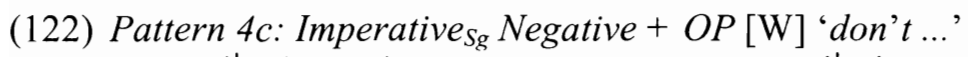
o-la-mú! [ßék-a] tá
'shave'
o-la-mú! [lól-a] tá
'see'
o-la-mú[ [rínd-a] tá o-la-mú! [línd-a] tá
'wait for'
o-la-mú[réé $\beta$-a] tá o-la-mú! [réé $\beta$-a] tá
'ask'

This difference suggests an influence on Wabala's grammar by Khayo, the majority dialect in Busia, the town where Wabala has lived for at least 15 years. 
Wabala's data in (120)-(122) have nearly the same tonal patterns as the corresponding data in Khayo (Marlo, to appear). The Khayo examples in (123)-(125) show that the melodic $\mathrm{H}$ surfaces on the initial mora of CVCV stems, on the second mora of CVVCV stems, and on the first mora of the second syllable of trisyllabic and longer stems in the same contexts. When there is a H-toned prefix preceding the stem, the melodic $\mathrm{H}$ is realized with a downstep in CVCV stems but as a level $\mathrm{H}$ without downstep in CVVCV stems, due to a rule of Plateau, which turns intermediate CV́CVV́ into CV́CV́V́. Wabala appears to derive the forms in (120)- (122) as in Khayo and not as in Okumu's idiolect of Tura, the only difference being that CV́CVV́ turns into $\mathrm{CV}^{!} \mathrm{CV}^{\mathrm{V}}$ in Wabala's idiolect.

(123) Khayo Indefinite Future Negative

-OP 'he will not ...'

$+O P$ ' he will not ... him'

$\begin{array}{ll}\text { s-áa-li[ßék-a] } & \text { 'shave' } \\ \text { s-áa-li[reéß-a] } & \text { 'ask' } \\ \text { s-áa-li[ßukúl-a] } & \text { 'take' } \\ \text { s-áa-li[siindix-a] } & \text { 'push' }\end{array}$

$\begin{array}{ll}\text { s-áa-li-mú![ßék-a] } & \text { 'shave' } \\ \text { s-áa-li-mú[réé } \beta-a] & \text { 'ask' } \\ \text { s-áa-li-mú[ßukúl-a] } & \text { 'take' } \\ \text { s-áa-li-mú[siindix-a] } & \text { 'push' }\end{array}$

(124) Khayo Immediate Past Negative 'he did not just ...'

\begin{tabular}{|c|c|c|}
\hline ś1-y-a-xá![ßék-a] & 'shave' & ś́-y-a-xá[réé $\beta-a]$ \\
\hline ś́-y-a-xá[ßukúl-a] & 'take' & ś1-y-a-xá[fuund'x-a] \\
\hline
\end{tabular}

(125) Khayo Imperative Sg Negative

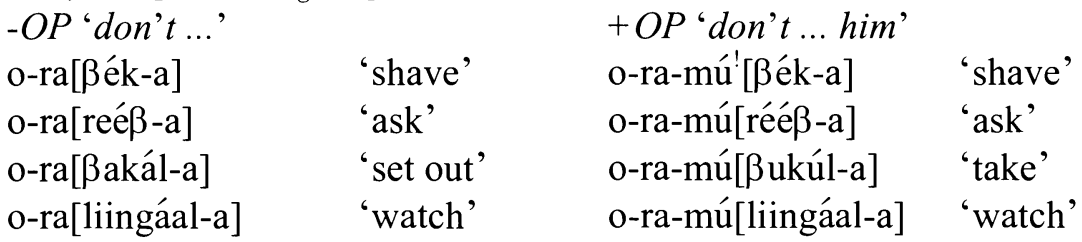

A further case that supports the conclusion that Wabala derives Pattern 2 and Pattern $4 \mathrm{c}$ forms as in Khayo and not as in Okumu's idiolect of Tura is the tonal pattern of monosyllabic stems in Pattern 2a, which surface toneless in Wabala's idiolect, as in Khayo forms like $s$-áa-li[xw-a] 'he will not pay the dowry', cf. $s$-áa-li[fw-á] tá $[\mathrm{O}]$ 'he will not die'.

(126) Pattern 2a: Indefinite Future Negative [W] 'he will not ...' s-áa-li[fw-a] tá 'die' śs-ßa-li[tsy-a] tá 
8.5 Leftward spread in Pattern 1. The rules of leftward spread that apply in Pattern 1 also show influence from Khayo. In disyllabic stems, the melodic $\mathrm{H}$ spreads to both moras of the stem-initial syllable in Okumu's idiolect, even when there is a H-toned prefix preceding the stem (see (119)). Wabala shows variation in Pattern 1 forms when the stem is preceded by a $\mathrm{H}$-toned prefix. The examples in (127) show that the melodic $\mathrm{H}$ is optionally not realized on the initial mora of CVCV stems, while the only possible pronunciation of CVVCV stems has the melodic $\mathrm{H}$ on both moras of the stem-initial syllable, realized at the same pitch level as the preceding $\mathrm{H}^{27}$ (Wabala's Pattern 1a Indefinite Future forms did not show this variation-likely an accident. See (139) in the appendix for additional Present tense examples with an object prefix).

\section{(127) Pattern la: Present disyllabic stems $+O P$ [W] 'he is ...ing him' a-mú[ßék-á] a-mú[ßek-á] 'shave' a-mú[ß̈́r-á] a-mú[ßir-á] 'pass' a-mú[réé $\beta$-á], *a-mú[reeß $\beta$-á] 'ask'}

There is also variation in Pattern $1 \mathrm{~b}$ tenses such as the Near Future (see section 10.2 for further examples of this variation). As shown in (128), the moras of disyllabic stems are optionally toneless; the moras of the stem-initial syllable are either all $\mathrm{H}$ or all toneless.

\section{(128) Pattern Ib: Near Future disyllabic stems [W] 'he will ...' \\ a-lá[ßék-á] a-lá[ßek-á] 'shave' a-lá[xín-á] a-lá[xin-á] 'dance' \\ a-lá[tééx-á] a-lá[teex-á] 'cook' a-lá[xwéés-á] a-lá[xwees-á] 'pull'}

The Near Future examples with an object prefix in (129) also have the pronunciation in which the moras of the stem-initial syllable are toneless. If we take into consideration data from other Pattern $1 \mathrm{~b}$ tenses, such as the Remote Future Negative (see (176) in the appendix), we find at least some examples where Wabala pronounces $\mathrm{CVCV}$ and $\mathrm{CVVCV}$ stems with a $\mathrm{H}$ on the moras of the steminitial syllable, as we find consistently in Okumu's data.

\footnotetext{
${ }^{27}$ Wabala suggested that there may be a pragmatic difference between the two possible forms in Tura, but the distinction-between witnessing an event and telling someone else who can see the same event $\left(C V^{\prime} C V^{\prime}\right)$ vs. the general reporting of information (CVCV́)-seems not to be possible for other stem shapes. Further study is required to determine whether there may be other grammatical marking of such contrasts in Tura and whether other variations in Wabala's speech have specialized meanings.
} 
(129) Pattern 1b: Near Future + OP disyllabic stems [W] 'he will ... him'

\begin{tabular}{|c|c|c|}
\hline $\begin{array}{l}\text { a-lá-mu[ßek-á] } \\
\text { a-lá-mu[liind-á] }\end{array}$ & $\begin{array}{l}\text { 'shave' } \\
\text { 'wait for' }\end{array}$ & $\begin{array}{l}\text { a-lá-mu[lol-á] } \\
\text { a-lá-mu[ree } \beta \text {-á] }\end{array}$ \\
\hline
\end{tabular}

With the exception of Immediate Past forms discussed below, the various attested examples of VCV stems with an object prefix in Pattern $1 \mathrm{~b}$ all have a toneless stem-initial syllable. In this context, Wabala seems to consistently differ from Okumu, who produces such forms with a rise on the deried long stem-initial syllable, e.g., $a-l a ́-m w[a a ́ r-a ́]$ 'he will operate on him'.

\section{(130) Pattern 1b: Near Future + OP VCV stems [W] 'he will ... him'} a-lá-mw[aar-á] 'operate on' a-lá-mw[iir-á] 'kill'

Wabala produced the disyllabic stems in the Immediate Past in (131) without any variation and just like Okumu-with a $\mathrm{H}$ on the mora of the stem-initial syllable (see also (153) and (155) in the appendix). Similarly, Wabala produced examples of VCV stems with an object prefix on parallel with Okumu's: $y$-a-xá'$m w[a ́ a r r-a ́]$ 'he did not just operate on him', in which the melodic $\mathrm{H}$ extends onto the stem-initial mora, subsequently undergoing Rise Elimination or Plateau (see section 8.2 for a discussion of Rise Elimination and Plateau, and (156) for additional examples of $\mathrm{V}$-initial stems with an object prefix). While the complete lack of variation in the Immediate Past is surprising, the fact that these forms are tonally identical to Pattern 1a forms with an object prefix and unlike other Pattern $1 \mathrm{~b}$ forms is predicted by the hypothesis that Okumu is influenced by Khayo, since, as we see below, the Immediate Past is functionally equivalent to Pattern 1a forms with an object prefix in Khayo, while tenses like the Near Future have a different tonal pattern. I predict that further investigation would reveal that Wabala has the same range of variation in the Immediate Past as in Pattern 1a forms with an object prefix, where CVCV stems vary in whether the stem-initial initial mora is $\mathrm{H}$ or Ø.

(131) Pattern 1b: Immediate Past disyllabic stems

\begin{tabular}{|c|c|c|}
\hline -OP 'he just ...' & & $+O P$ 'he just ... him' \\
\hline y-a-xá[lól-á] & ‘saw' & y-a-xá-mu[ßék-á] \\
\hline y-a-xá[rééß-á] & 'asked' & y-a-xá-mu[réé $\beta$-á] \\
\hline
\end{tabular}


Turning now to Pattern 1 forms in Khayo (Marlo, to appear), we can see in the Indefinite Future forms in (132) that the melodic $\mathrm{H}$ spreads left by one mora into the initial syllable of disyllabic stems, but the melodic $\mathrm{H}$ does not spread onto the moras of the initial syllable of trisyllabic and longer stems. In CVVCV stems, the melodic $\mathrm{H}$ is realized only on the second half of the stem-initial syllable. Unlike in Okumu's idiolect of Tura, the leftward spread of the melodic $\mathrm{H}$ is sensitive to the presence of a $\mathrm{H}$ on its left in Khayo. When an object prefix immediately precedes the stem, the melodic $\mathrm{H}$ does not surface on the initial mora of CVCV stems, while the stem-initial syllable has a level $\mathrm{H}$ with no downstep in CVVCV stems, due to the rule of Plateau described above, which renders intermediate $a$-li$m u ́[r e e ́ \beta-a ́]$ into the surface form.

\section{(132)}

Khayo Indefinite Future

-OP 'he will ...'

$+O P$ 'he will ... him'

\begin{tabular}{|c|c|c|}
\hline a-li[ßék-á] & 'shave' & a-li-mú[ßek-á] \\
\hline a-li[reé $\beta$-á] & 'ask' & a-li-mú[réé $\beta$-á] \\
\hline a-li[ßukúl-á] & 'take' & a-li-mú[ßukúl-á] \\
\hline
\end{tabular}

The fact that Wabala varies between stem-initial $H$ and $\varnothing$ in CVCV stems can be explained as the maintenance of the typical Tura form (a-mú[ßék-á]) as well as the Khayo variant ( $a-m u ́[\beta e k-a ́])$. CVVCV stems with an object prefix are identical in Tura and Khayo (a-mú[réé $\beta$-á]). The rise on the stem-initial syllable of CVVCV stems in Khayo (a-li[réé-á]) would be rendered into level H by Wabala and would be identical to the typical Tura form of CVVCV stems.

The data from the Immediate Past in (133) show that the H-toned prefix $x a$ has the same tonal effects as the object prefix in the Indefinite Future: the melodic $\mathrm{H}$ does not surface on the stem-initial mora when the H-toned prefix immediately precedes the stem, and the melodic $\mathrm{H}$ undergoes Plateau in CVVCV stems. The forms with an object prefix show that when Meeussen's Rule deletes the $\mathrm{H}$ of the object prefix, the same stem tone patterns are found as in the Indefinite Future.

(133) Khayo Immediate Past

-OP 'he just ...ed'

$+O P$ 'he just ...ed him'

y-a-xá[ßek-á] 'shave'

y-a-xá-mu[ßék-á] 'shave'

y-a-xá[réé $\beta$-á]

'ask'

y-a-xá-mu[reé $\beta$-á]

'ask'

y-a-xá[ßukúl-á]

'take'

y-a-xá-mu[ßukúl-á] 'take' 
Wabala's Immediate Past data are identical to the Khayo Immediate Past forms with an object prefix, but there is a difference between the Khayo forms and Wabala's data with no object prefix in that no examples of CVCV stems were attested in Wabala's data with a stem-initial toneless mora. As noted above, this is taken to be an accidental gap in the present corpus of data from Wabala.

There is a striking difference among Pattern 1 tenses with a H-toned tense prefix in Khayo. Unlike the Immediate Past, the melodic $\mathrm{H}$ never surfaces on the moras of the stem-initial syllable in the Near Future (or Remote Future), which has the H-toned tense prefix ná- (Remote Future $x a ́$-), even when the H-tone immediately preceding the stem is deleted by Meeussen's Rule.

(134) Khayo Near Future

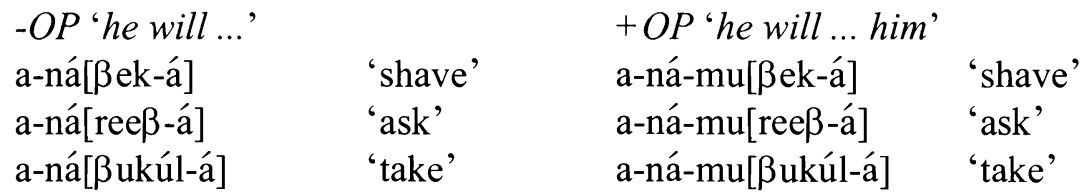

The fact that Near Future forms in Khayo never realize the melodic $\mathrm{H}$ on the moras of the stem-initial syllable explains the variant Pattern $1 \mathrm{~b}$ forms in Wabala's idiolect that lack $\mathrm{H}$ on the moras of the stem-initial syllable. Additionally, the fact that Khayo treats the Near Future and other Pattern $1 \mathrm{~b}$ tenses differently from the Immediate Past helps to explain why Wabala treats the Immediate Past differently from Pattern $1 \mathrm{~b}$ tenses with respect to leftward spread.

8.6 The reflexive. The final context in which there is a tonal difference between Okumu's and Wabala's idiolects is in Pattern la forms with the reflexive. As shown in the examples in (135), a $\mathrm{H}$ is realized on all moras of the stem, including the moras of the stem-initial syllable. (Parallel data showing the same tonal patterns for Wabala in the Present and Hesternal Perfective are in (145) and (152) in the appendix.) This is unlike the forms described above for Okumu, in which the moras of the stem-initial syllable are toneless in trisyllabic and longer stems, e.g., a-ly-ee[kaangúlúl-á] 'he will untie himself'.
(135) Pattern Ia: Indefinite Future $+O P_{\text {Refl }}[\mathrm{W}]$ 'he will ... himself' a-ly-ee[ßék-á] 'shave' a-ly-ee[ßóólól-á] 'untie' a-ly-ee[kárááng-ír-á] ' fry for' a-ly-ee[káángúlúl-á] 'untie' 
The moras of the stem-initial syllable surface toneless in the Pattern $1 \mathrm{~b}$ forms in (136), which is consistent with the generalization that the moras of the stem-initial syllable surface toneless in all Pattern $1 \mathrm{~b}$ forms (with two or more syllables in the stem).

\section{(136) Pattern 1b: Near Future $+O P_{\text {Refl }}[\mathrm{W}]$ 'he will ... himself'

\begin{tabular}{|c|c|}
\hline a-l-ée $[\beta$ ek-á] & 'shave', \\
\hline
\end{tabular}

Wabala's Pattern la data are interesting since the moras of the stem-initial syllable acquire a $\mathrm{H}$ in Pattern 4 in Okumu's idiolect (and in light of the fact that Pattern $1 \mathrm{~b}$ forms in Wabala's idiolect do not acquire the same H). However, reflexive data have not been collected from Wabala in all of the relevant melodic contexts, so it is not possible to provide an analysis of the tonal patterns of the reflexive in Wabala's idiolect.

To conclude this section, we can note that the majority of the surface tonal patterns in Okumu's and Wabala's idiolects are identical, particularly in trisyllabic and longer stems (which generally have the same surface tonal patterns in Tura and Khayo), but there are significant differences, too. Some of these differences, such as the fact that Wabala renders potential rising tones into level Hs, are trivial and can be accounted by the simple addition of a rule to Wabala's tonal grammar. On the other hand, variants of the tonal patterns of CVCV stems in Patterns 1,2 , and $4 \mathrm{c}$ after a $\mathrm{H}$-toned prefix suggest that Wabala derives these forms with the same rules as in Khayo. For many of these same examples, Wabala also produced the form that is identical to the one produced by Okumu, but there are some contexts where Wabala produced only the Khayo form, such as melodic $\mathrm{H}$ on monosyllabic stems in Pattern 2a. At the time data was collected from Wabala, it was not known that Okumu and the Khayo speaker I would later collect data from would have only a single pronunciation of these forms, so I did not directly question Wabala on these differences (or on whether Pattern 2a forms could be pronounced with a melodic H). It is therefore difficult to tell whether any of these variants were production "errors", whether Wabala (subconsciously) code-switched between Khayo and Tura, or whether he has a grammar that produces multiple grammatical forms. Differentiating among these interpretations and determining how the tonal grammars of other Tura speakers compare to Okumu and Wabala remain tasks for future research. 


\section{Conclusion.}

While there remain some questions concerning the proper interpretation of dialect variation, we have seen conclusively that the Tura tonal system has a large number of tonal melodies that interact intricately with H-toned prefixes and the prosody of the verb stem to which they are mapped. The complex differences across the melodies have been accounted for here with a relatively simple analysis in which morphologically specific rules of Melodic H Assignment are parameterized to be sensitive (or not) to the absence or presence of a preceding $\mathrm{H}$ and by ordering these rules with respect to other rules such as Object $\mathrm{H}$ Assignment and Doubling.

\section{Appendix.}

\subsection{Pattern 1a}

(137) Present 'he is ...ing'

$\mathrm{a}[\mathrm{ly}-\mathrm{a}]$

a[ßék-á]

a[ßukúl-á]

a[fuundix-á]

a[lomálóm-á]

a[liingáál-ááng-á] 'eat'

'shave'

'take'

'knot'

'talk'

'watch' a[nyw-á]

a[tééx-á]

a[karááng-á]

a[liingéér-á]

a[karááng-ááng-á]

a[lomálóm-ááng-á] 'drink'

'cook'

'fry'

'watch'

'fry'

'talk'

(138) Present V-initial stems 'he is ...ing'

y[eémb-á]

y[eerúx-á]

y[ool-ááng-á] 'sing'

'run'

'arrive' y[oól-á] [W]

y[aandı́ı́k-á]

y[eexál-ááng-á] 'arrive'

'write'

'sit'

(139) Present $+O P$ 'he is ...ing him'

$\begin{array}{ll}\text { a-mú[ry-á] } & \text { 'fear' } \\ \text { a-mú[ßék-á] } & \text { 'shave' } \\ \text { a-mú[ßukúl-á] } & \text { 'take' } \\ \text { a-mú[ßoolól-á] } & \text { 'untie' }\end{array}$

a-mú[xw-á]

a-mú[réé $\beta$-á]

a-mú[lexúúl-á]

a-mú[liingéér-á] 'pay dowry'

'ask'

'release'

'watch' 
(140) Present + OP disyllabic stems [W] 'he is ...ing him'

\begin{tabular}{|c|c|c|}
\hline $\begin{array}{l}\text { a-mú[ßék-á] } \\
\sim \text { a-mú[ßek-áa } \\
\text { a-mú[lóónd-á] }\end{array}$ & $\begin{array}{l}\text { 'shave' } \\
\text { 'follow' }\end{array}$ & $\begin{array}{l}\text { a-mú[ßír-á] } \\
\sim \text { a-mú[ßir-á] } \\
\text { a-mú[réé } \beta \text {-á] }\end{array}$ \\
\hline
\end{tabular}

(141) Present + OP V-initial stems 'he is ...ing him ${ }^{28}$

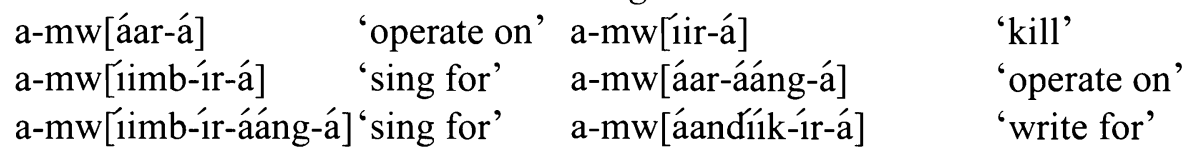

(142) Present $+O P_{l s g}[\mathrm{O}]$ ' he is ...ing me'

$\begin{array}{llll}\text { y-aá[ry-á] } & \text { 'fear' } & \text { y-aá[nzár-á] } & \text { 'operate on' } \\ \text { y-aá[ndééß-á] } & \text { 'ask' } & \text { y-aá[mbukúl-á] } & \text { 'take' } \\ \text { y-aá[ndexúul-á] } & \text { 'release' } & \text { y-aá[siindix-á] } & \text { 'push' } \\ \text { y-aá[niingéer-á] } & \text { 'watch' } & \text { y-aá[mbodóóxán-á] } & \text { 'go around' }\end{array}$

(143) Present $+O P_{l s g}[\mathrm{~W}]$ ' he is ...ing me'

$\begin{array}{llll}\text { y-aá[nzar-á] } & \text { 'operate on' } & \text { y-aá[nźrr-á] y-aá[nzir-áa] 'kill' } \\ \text { y-aá[ndééß-á] } & \text { 'ask' } & \text { y-aá[nyimb-ír-á] } & \text { 'sing for' } \\ \text { y-aá[mboolól-á] } & \text { 'untie' } & \text { y-aá[nyandík-ír-á] } & \text { 'write for' }\end{array}$

(144) Present $+O P_{\text {Refl }}[\mathrm{O}]$ 'he is ...ing himself'

$\begin{array}{llll}\text { y-ee[ry-á] } & \text { 'fear' } & \text { y-ee[ßék-á] } & \text { 'shave' } \\ \text { y-ee[rééß-á] } & \text { 'ask' } & \text { y-ee[y-imb-ir-á] } & \text { 'sing for' } \\ \text { y-ee[teex-ér-á] } & \text { 'cook for' } & \text { y-ee[ßek-ááng-á] } & \text { 'shave' } \\ \text { y-ee[karááng-ir-á] } & \text { 'fry for' } & \text { y-ee[kaangúlúl-á] } & \text { 'untie' }\end{array}$

${ }^{28}$ In some longer $\mathrm{V}$-initial stems with an object prefix, the sequence of stem-initial fall followed by $\mathrm{H}$ may be more narrowly transcribed as a long level $\mathrm{H}$ followed by downstepped $\mathrm{H}$. This phenomenon seems to be related to speech rate such that shorter stems pronounced more quickly seem to have a more nearly level $\mathrm{H}$ on the stem-initial syllable, and longer stems pronounced more slowly have a greater phonetic contour on the same syllable. For these reasons, and because any level $\mathrm{H}$ in this position derives from an earlier representation having a fall, we take leveling to be a phonetic effect here and provide a phonological transcription with $\mathrm{H}$ linked only to the initial mora of the long syllable, i.e. fall. 
(145) Present $+O P_{R e f l}[W]$ 'he (y-) is ...ing himself, I (nd-) am ...ing myself'
y-ee[ßék-á]
'shave'
nd-ee[fwímb-á]
'cover'
y-ee[tééx-ér-á]
y-ee[káángúlúl-á]
'cook for' y-ee[kárááng-ír-á]
'fry for'
'untie'

(146) Hesternal Perfective 'he ...ed'

\begin{tabular}{|c|c|c|}
\hline y-aa[1-1́ı́ré] & 'eat' & y-aa[kon-éré] \\
\hline y-aa[teex-éré] & 'cook' & y-aa[ßukúúl-é] \\
\hline y-aa[ßoolóól-é] & 'untie' & y-aa[karááng-íré] \\
\hline y-aa[liingáál-1ré] & 'look’ & y-aa[kaangúlúúl-é] \\
\hline
\end{tabular}

(147) Hesternal Perfective V-initial stems 'he ...'

y[eemb-éré] 'sang' y[aandúlk-íré] 'wrote'

(148) Hesternal Perfective $+O P$ 'he ...ed him'

$\begin{array}{llll}\text { y-aa-mú[r-íré] } & \text { 'fear' } & \text { y-aa-mú[ßek-éré] } & \text { 'shave' } \\ \text { y-aa-mú[reeß-éré] } & \text { 'ask' } & \text { y-aa-mú[ßukúul-é] } & \text { 'take' } \\ \text { y-aa-mú[reer-éér-é] } & \text { 'bring for' } & \text { y-aa-mú[saangáás-11s-y-é] } & \text { 'please' }\end{array}$

(149) Hesternal Perfective + OP V-initial stems 'he ...ed him'

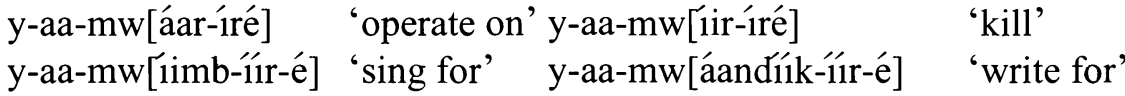

(150) Hesternal Perfective $+O P_{1 s g}[\mathrm{O}]$ 'he ...ed me'

$\begin{array}{llll}\text { y-aá[r-'íré] } & \text { 'fear' } & \text { y-aá[mbek-éré] } & \text { 'shave' } \\ \text { y-aá[ndeeß-éré] } & \text { 'ask' } & \text { y-aá[mbukúúl-é] } & \text { 'take' } \\ \text { y-aá[mboolóól-é] } & \text { 'untie' } & \text { y-aá[ndexúúl-iré] } & \text { 'release' } \\ \text { y-aá[niingéér-éré] } & \text { 'watch' } & \text { y-aá[mbodóóxáán-é] } & \text { 'go around' }\end{array}$

(151) Hesternal Perfective $+O P_{\text {Refl }}[\mathrm{O}]$ 'he ...ed himself'

$\begin{array}{llll}\text { y-ee[r-1ıré] } & \text { 'fear' } & \text { y-ee[ßek-éré] } & \text { 'shave' } \\ \text { y-ee[fwaal-iré] } & \text { 'dressed' } & \text { y-ee[teex-ééré] } & \text { 'cook for' } \\ \text { y-ee[karááng-1́r-é] } & \text { 'fry for' } & \text { y-ee[kaangúlúul-é] } & \text { 'untie' }\end{array}$

(152) Hesternal Perfective $+O P_{\text {Refl }}[\mathrm{W}]$ 'he ... himself'

$\mathrm{y}$-ee[r-11ré] 'feared'

y-ee[ßék-éré]

y-ee[y-imb-1̈r-é]

'sang to'

y-ee[tééx-ééré]

y-ee[kárááng-1́ır-é]

'fried for' y-ee[káángúlúúl-é] 'shaved'

'cooked for'

'untied' 


\subsection{Pattern 1b}

(153) Immediate Past 'he just ...ed'

$\begin{array}{llll}\text { y-a-xá[ly-á] } & \text { 'eat' } & \text { y-a-xá[nyw-á] } & \text { 'drink' } \\ \text { y-a-xá[lól-á] } & \text { 'see' } & \text { y-a-xá[rééß-á] } & \text { 'ask' } \\ \text { y-a-xá[ßukúl-á] } & \text { 'take' } & \text { y-a-xá[karááng-á] } & \text { 'fry' } \\ \text { y-a-xá[lexúúl-á] } & \text { 'let go' } & \text { y-a-xá[fuundix-á] } & \text { 'knot' } \\ \text { y-a-xá[liingéér-á] } & \text { 'watch' } & \text { y-a-xá[fuundúlúx-á] } & \text { 'unknot' }\end{array}$

(154) Immediate Past V-initial stems 'he just ...ed'
y-a-x[áar-á]
'operate'
y-a-x[éemb-á]
y-a-x[éexál-á]
'sit'
y-a-x[áanđ̛́ík-á]
'sing'
'write'

(155) Immediate Past $+O P$ 'he just ...ed him'

$\begin{array}{llll}\text { y-a-xá-mu[ry-á] } & \text { 'fear' } & \text { y-a-xá-mu[ßék-á] } & \text { 'shave' } \\ \text { y-a-xá-mu[rée-á] } & \text { 'ask' } & \text { y-a-xá-mu[ßukúl-á] } & \text { 'take' } \\ \text { y-a-xá-mu[lexúúl-á] } & \text { 'release' } & \text { y-a-xá-mu[ßoolól-á] } & \text { 'untie' } \\ \text { y-a-xá-mu[liingéer-á] } & \text { 'watch' } & y \text {-a-xá-mu[karááng-ir-á] } & \text { 'fry for' }\end{array}$

(156) Immediate Past + OP V-initial stems 'he just ...ed him'

y-a-xá-mw[aár-á] [O] 'operate on' y-a-xá-mw[ïrrá] [O] 'kill'

y-a-xá'-mw[áár-á] [W] 'operate on' y-a-xá'-mw['ír-á] [W] 'kill'

y-a-xá-mw[iimb-ír-á] 'sing for' y-a-xá-mw[aandúḱ-ír-á] 'write for'

(157) Immediate Past $+O P_{l s g}[\mathrm{O}]$ 'he just ...ed me'

$\begin{array}{llll}\text { y-a-xáa[ry-á] } & \text { 'fear' } & \text { y-a-xáa[nzár-á] } & \text { 'operate on' } \\ \text { y-a-xáa[nźir-á] } & \text { 'kill' } & \text { y-a-xáa[ndééß-á] } & \text { 'ask' } \\ \text { y-a-xáa[níind-á] } & \text { 'wait for' } & \text { y-a-xáa[mbukúl-á] } & \text { 'take' } \\ \text { y-a-xáa[mboolól-á] } & \text { 'untie' } & \text { y-a-xáa[ndexúúl-á] } & \text { 'release' } \\ \text { y-a-xáa[niingéér-á] } & \text { 'watch' } & \text { y-a-xáa[mbodóóxán-á] } & \text { 'go around' }\end{array}$

(158) Immediate Past $+O P_{\text {lsg }}[\mathrm{W}]$ 'he just ...ed me'
y-a-xáa[nzár-á]
'operate on' y-a-xáa[nźrr-á]
'kill'
y-a-xáa[nyimb-ír-á]
'sing for'
y-a-xáa[mbukúl-á]
'take' 
(159) Immediate Past $+O P_{\text {Refl }}$ 'he just ...ed himself ${ }^{29}$

$\begin{array}{llll}\text { y-a-x-ée[ry-á] [O] } & \text { 'fear' } & \text { y-a-x-ée[ßék-á] } & \text { 'shave' } \\ \text { y-a-x-ée[rééß-á] [O] } & \text { 'ask' } & \text { y-a-x-ée[fumír-á] [O] } & \text { 'stab' } \\ \text { y-a-x-ée[lexúúl-á] [O] } & \text { 'release' } & \text { y-a-x-ée[teex-ér-á] } & \text { 'cook for' } \\ \text { y-a-x-ée[y-asyáák-ir-á] } & \text { 'split for' } & & \end{array}$

(160) Near Future Negative 'he will not ..., 30

$\begin{array}{llll}\text { s-áa-lá[ly-á] tá } & \text { 'eat' } & \text { s-áa-lá[nyw-á] tá } & \text { 'drink' } \\ \text { s-áa-lá[kón-á] tá } & \text { 'sleep' } & \text { s-áa-lá[tééx-á] tá } & \text { 'cook' } \\ \text { s-áa-lá[ßukúl-á] tá } & \text { 'take' } & \text { s-áa-lá[karááng-á] tá } & \text { 'fry' } \\ \text { s-áa-lá[fuundix-á] tá } & \text { 'knot' } & \text { s-áa-lá[liingéerr-á] tá } & \text { 'watch' }\end{array}$

(161) Near Future Negative V-initial stems 'they will not ...'

\begin{tabular}{|c|c|c|}
\hline 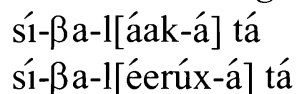 & $\begin{array}{l}\text { 'weed' } \\
\text { 'run' }\end{array}$ & 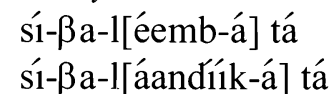 \\
\hline
\end{tabular}

(162) Near Future Negative + OP 'they will not ... him'
sí-ßa-lá-mu[ry-á] tá
'fear'
sí-ßa-lá-mu[xw-á] tá
'pay
dowry'
sí-ßa-lá-mu[ßék-á] tá [O] 'shave'
sí-ßa-lá-mu[réé $\beta$-á] tá [O]
'ask'

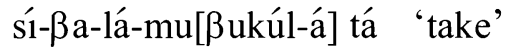

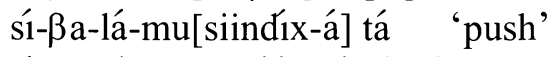 sí-ßa-lá-mu[liingéér-á] tá 'watch' ś1-ßa-lá-mu[karááng-ír-á] tá 'fry for'
(163) Near Future Negative + OP disyllabic stems $[W]$ 'they will not ... him'

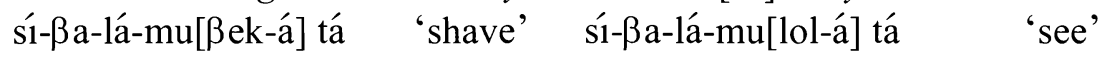

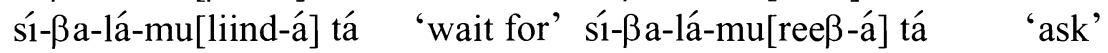

\footnotetext{
${ }^{29}$ The $\mathrm{H}$ on the reflexive ée- sounds more like level $\mathrm{H}$ than fall in a few of these forms. This is likely a phonetic effect related to speech rate, delay of the $\mathrm{H}$ peak, or to the voicelessness of certain stem-initial consonants, as in the roots teex- 'cook' and karaang- 'fry'.

${ }^{30}$ Several of Wabala's pronunciations of these forms, particularly those with long verb stems, are not clear and are difficult to transcribe. A few examples with trisyllabic stems seem to be pronounced with a $\mathrm{H}$ from the tense prefix to the stem-final mora. A few other cases appear to be toneless from the tense prefix to the stem-final mora, as in Pattern 4c. These questionable forms are pronounced with sufficiently low amplitude that they should not be the basis of an analysis and should be re-elicited. There are a few examples, however, whose pronunciations are consistent with the relatively clear pronunciations of Okumu, having a toneless stem-initial syllable, followed by $\mathrm{H}$ on all subsequent moras.
} 
(164) Near Future Negative $+O P$ V-initial stems 'they will not ... him' sí-ßa-lá-mw[aár-á] tá [O] sí-ßa-lá-mw[ír-á] tá [O] 'operate on'

sí-ßa-lá-mw[aar-á] tá [W] sí-ßa-lá-mw[iir-á] tá [W] sí-ßa-lá-mw[iimb-ir-á] tá sí-ßa-lá-mw[aandíik-ír-á] tá

'kill'

'operate on'

'kill'

'sing for'

'employ'

(165) Remote Future 'he will ...'

y-a-xá[fw-é] 'die'

y-a-xá[ßék-é] 'shave'

y-a-xá[ly-é]

y-a-xá[réé $\beta$-é]

y-a-xá[ßukúl-é] 'take'

y-a-xá[ßoolól-é] 'untie' y-a-xá[lexúúl-é]

y-a-xá[liingéér-é] 'eat'

'ask'

'release'

'watch'

(166) Remote Future disyllabic stems [W]'he will ...'

y-a-xá[ßék-é] y-a-xá[ßek-é] 'shave'

y-a-xá[xín-é] y-a-xá[xin-é] 'dance'

y-a-xá[réé $\beta$-é] y-a-xá[reeß-é] ' 'ask'

y-a-xá[tééx-é] y-a-xá[teex-é] 'cook'

(167) Remote Future V-initial stems 'he will ...'

y-a-x[éemb-é] 'sing'
(168) Remote Future + OP 'he will ... him' him '

y-a-xá-mu[ry-é] ' 'fear'

y-a-xá-mu[ßék-é] [O] 'shave'

y-a-xá-mu[réé $\beta$-é] 'ask'

y-a-xá-mu[ßukúl-é]

'come'

y-a-xá-mu[teex-ér-é]

'cook for'

y-a-xá-mu[lexúúl-é]

'release'

y-a-xá-mu[liingéer-é]

'watch'

y-a-xá-mu[ßßotóóxán-é]

'go around'

(169) Remote Future + OP disyllabic stems [W] 'he will ... him' y-a-xá-mu[ßek-é] 'shave' y-a-xá-mu[rem-é]

'split wood'

y-a-xá-mu[l'índ-é] y-a-xá-mu[liind-é]

y-a-xá-mu[réé $\beta$-é] y-a-xá-mu[reeß $\beta$-é]

'chop'
'wait for'
'ask' 
(170) Remote Future + OP V-initial stems 'he will ... him' y-a-xá-mw[aár-é] [O] 'operate on' $\quad \mathrm{y}$-a-xá-mw[írr-é] [O] 'kill' y-a-xá-mw[aar-é] [W] 'operate on' y-a-xá-mw[iir-é] [W] 'kill' y-a-xá-mw[iimb-ir-é] 'sing for' y-a-xá-mw[aasyáák-ir-é] 'split for'

(171) Remote Future $+O P_{\text {Isg }}[\mathrm{O}]$ ' he will ... me'

y-a-xáa[ry-é]

y-a-xáa[ndéé $\beta$-é]

y-a-xáa[mboolól-é]

y-a-xáa[niingéer-é] 'fear' y-a-xáa[mbék-é]

'ask' y-a-xáa[mbukúl-é]

'untie' y-a-xáa[ndexúúl-é]

'watch' y-a-xáa[mbodóóxán-é] 'shave'

'take'

'release'

'go

around'

(172) Remote Future $+O P_{\text {Refl }}[\mathrm{O}]$ ' he will ... himself'

y-a-x-ée[ry-é]

y-a-x-ée[réé $\beta$-é]

y-a-x-ée[lexúúl-é]

y-a-x-ée[karááng-ír-é] 'fear'

'ask'

'release' y-a-x-ée[ßßoolól-é]

'fry for' y-a-x-ée[kaangúlúl-é]

$y$-a-x-ée[fumir-é] y-a-x-ée[ßék-é]

'shave'

'stab'

'untie'

'untie'

(173) Remote Future $+O P_{\text {Refl }}[\mathrm{W}]$ 'he will ... himself'

y-a-x-ée[ßék-é] y-a-x-ée[ßek-é] 'shave'

$y$-a-x-ée[ßoolól-é] 'untie'

y-a-x-ée[karááng-ír-é] 'fry for'

y-a-x-ée[kaangúlúl-é] 'untie'

(174) Remote Future Negative 'he will not ...'

sí-y-a-xá[ly-é] tá

sí-y-a-xá[lím-é] tá

sí-y-a-xá[xalák-é] tá

sí-y-a-xá[fuundı́x-é] tá 'eat'

'dig'

'cut'

'knot' sí-y-a-xá[nyw-é] tá sí-y-a-xá[tééx-é] tá sí-y-a-xá[karááng-é] tá sí-y-a-xá[liingéér-é] tá 'drink'

'cook'

'fry'

'watch'

(175) Remote Future Negative V-initial stems 'he will not ...'

sí-y-a-x[áak-é] tá

sí-y-a-x[éerúx-é] tá 'weed'

'run' sí-y-a-x[éemb-é] tá

sí-y-a-x[áandúlk-é] tá 'sing'

'write'

(176) Remote Future Negative + OP 'he will not ... him'

sí-y-a-xá-mu[ry-é] tá

$$
\text { 'fear' }
$$

sí-y-a-xá-mu[réé $\beta$-é] tá 'ask'

śr-y-a-xá-mu[siindix-é] tá 'push' sí-y-a-xá-mu[ßék-é] tá

sí-y-a-xá-mu[lexér-é] tá sí-y-a-xá-mu[karááng-ir-é] tá 'fry for' 
(177) Remote Future Negative + OP disyllabic stems $[W]$ 'he will not ... him' sí-y-a-xá-mu[ßék-é] tá sí-y-a-xá-mu[ßek-é] tá sí-y-a-xá-mu[lól-é] tá

sí-y-a-xá-mu[línnd-é] tá sí-y-a-xá-mu[liind-é] tá

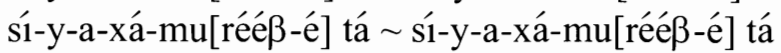

'shave' 'see'

'wait for'

'ask'

(178) Remote Future Negative + OP V-initial stems 'he will ... him'

sí-y-a-xá-mw[aár-é] tá [O]

ś́-y-a-xá-mw[írr-é] tá [O]

sí-y-a-xá-mw[iimb-ír-é] tá

sí-y-a-xá-mw[aandúik-ír-é] tá 'operate on'

'kill'

'sing for'

'write f.'

(179) Remote Future Negative + OP VCV stems [W] 'he will not ... him' ś-y-a-xá-mw[aar-é] tá 'operate on' sí-y-a-xá-mw[iir-é] tá 'kill'

(180) Remote Future Negative $+O P_{\text {Refl }}[\mathrm{O}]$ 'he will not ... himself'

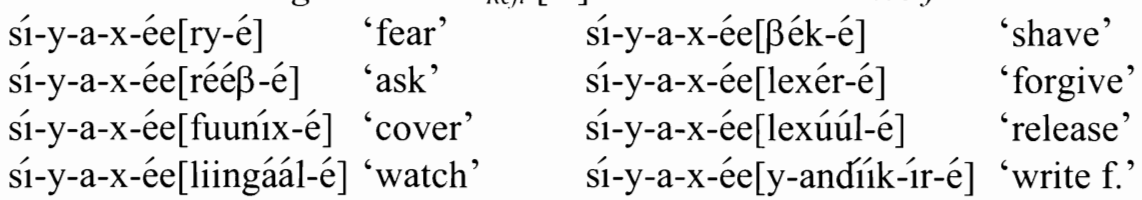

\subsection{Pattern 2a}

(181) Present Negative 'they are not ...ing'

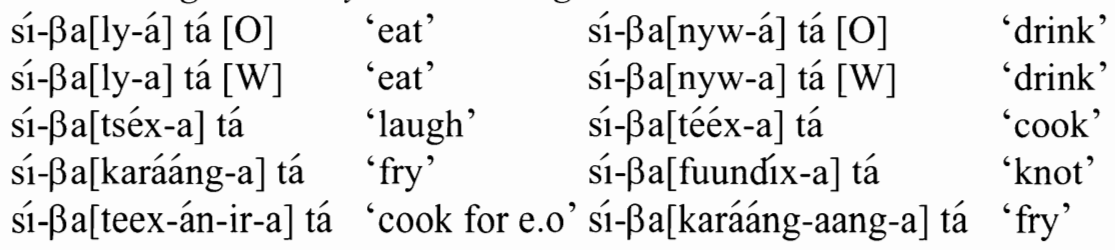

(182) Present Negative V-initial 'he is not ...ing'

$\begin{array}{llll}\text { sí-y[aak-ááng-a] tá } & \text { 'weed' } & \text { sí-y[eemb-ááng-a] tá } & \text { 'sing' } \\ \text { sí-y[eerúx-aang-a] tá } & \text { 'run' } & \text { sí-y[aandík-aang-a] tá } & \text { 'write' }\end{array}$ 
(183) Present Neg. + OP [O] 'he is / they are not ...ing him / them, 31

\begin{tabular}{|c|c|c|}
\hline ś1-ßa-mú[ry-a] tá [O] & 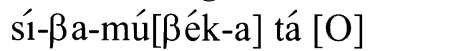 & 'shave' \\
\hline 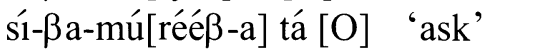 & 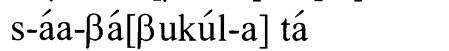 & 'take' \\
\hline 1-ßa-mú[lexúúl-a] tá [O] 'release' & ś1-ßa-mú[siindix-a] tá $[\mathrm{O}]$ & 'push' \\
\hline 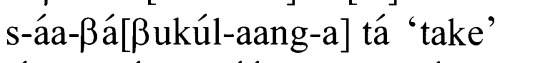 & si-ßa-mú[teex-ér-aang-a] tá & ook for' \\
\hline oéér-ano-al t & vatch' & \\
\hline -ßa-mú[karáng-ir-aang-a] tá & for' & \\
\hline
\end{tabular}

(184) Present Negative + OP V-initial 'they are not ...ing him'

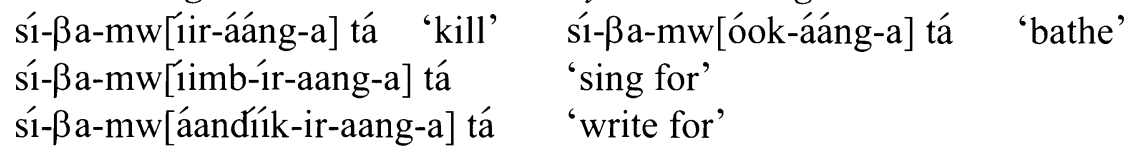

(185) Present Negative $+O P_{1 s g}[\mathrm{O}]$ 'he is not ...ing me'
sí-y-aá[ndy-a]
'eat' sí'-y-áá[ry-a]
'fear'
sí -y-áá[mbék-a]
'shave' s'́-y-áá[ndéé $\beta$-a]
'ask'
sí -y-áá[mbukúl-a]
'take' si'-y-áá[mboolól-a]
'untie'
sí-y-áá[ndexúúl-a]
'release' ś' -y-áá[mbotóóxan-a]
'go around'

(186) Hesternal Perfective Negative [W] 'he did not ...'

sí-y-aa[1-1́re] tá

sí-y-aa[reeß-ére] tá

śi-y-aa[fuundíix-e] tá 'eat'

'ask'

'knot' ś1-y-aa[kon-ére] tá

sí-y-aa[karááng-ire] tá

ś-y-aa[liingéér-ere] tá 'sleep'

'fry'

'watch'

\subsection{Pattern 3b}

(187) Imperative $p l$ 'you $(p l) \ldots$ !.')

[ly-é]

[ree $\beta$-é]

[karaang-é]

[saambuul-é]

$\begin{array}{ll}\text { 'eat' } & {[\beta \text { ek-é }]} \\ \text { 'ask' } & {[\beta \text { ukul-é] }} \\ \text { 'fry' } & {[\text { fuunix-é] }} \\ \text { 'de-roof' } & \text { [lomalom-é] }\end{array}$

'shave'

'take'

'cover'

'talk'

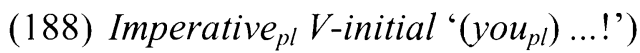

[y-ak-é]

[y-andiik-é] 'weed'

[irux-é]

[y-asyaak-é] 'run'

'split'

${ }^{31}$ Some of these forms with the $3 \mathrm{sg}$ subject prefix $a$ - sound like they have a level $\mathrm{H}$ followed by a downstepped H, i.e., sáá'-mú-, which is likely a phonetic implementation effect. 


\subsection{Pattern 4b}

(189) Crastinal Future [O] 'he will ...'

\begin{tabular}{|c|c|c|c|}
\hline n-aa[ly-é] & 'eat' & n-aa[tsy-é] & 'go' \\
\hline n-aa[ßék-e] & 'shave' & $\mathrm{n}$-aa[réé $\beta-\mathrm{e}]$ & 'ask' \\
\hline n-aa[ßukúl-e] & 'take' & n-aa[lexúúl-e] & 'release' \\
\hline n-aa[siindix-e] & 'push' & n-aa[liingáál-e] & 'watch' \\
\hline n-aa[ßßodóóxan-e] & 'go around' & n-aa[lomálom-e] & 'talk’' \\
\hline
\end{tabular}

(190) Crastinal Future $+O P[\mathrm{O}]$ 'he will ... him'

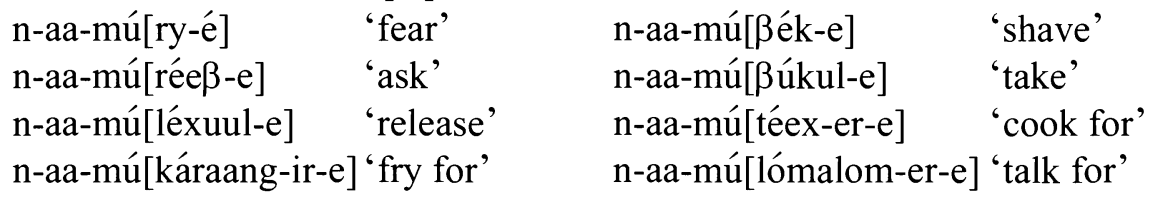

(191) Crastinal Future $+O P_{l s g}[\mathrm{O}]$ ' he will ... me'

$\begin{array}{llll}\text { ni-y-aá[ry-é] } & \text { 'fear' } & \text { n-aá[nzír-e] } & \text { 'kill', } \\ \text { n-aá[réeß-e] } & \text { 'ask' } & \text { n-aá[mbúkul-e] } & \text { 'take' } \\ \text { n-aá[ndéxuul-e] } & \text { 'release' } & \text { n-aá[mbóolol-e] } & \text { 'untie' } \\ \text { n-aá[níingeer-e] } & \text { 'watch' } & \text { n-aá[mbótooxan-e] } & \text { 'go around' }\end{array}$

(192) Crastinal Future + OP V-initial stems [O] 'he will ... him' n-aa-mw[áár-e] 'operate on' n-aa-mw['ímb-ir-e] 'sing for' n-aa-mw[áándiik-e] 'employ' n-aa-mw[áásyaak-ir-e] 'split for'

(193) Crastinal Future $+O P_{\text {Refl }}[\mathrm{O}]$ ' he will ... himself'

$\begin{array}{llll}\text { ni-y-ee[ry-é] } & \text { 'fear' } & \text { ni-y-ee[ßék-e] } & \text { 'shave' } \\ \text { ni-y-ee[rééß-e] } & \text { 'ask' } & \text { ni-y-ee[fúmir-e] } & \text { 'stab' } \\ \text { ni-y-ee[léxuul-e] } & \text { 'release' } & \text { ni-y-ee[ßóólol-e] } & \text { 'untie' } \\ \text { ni-y-ee[língeer-e] } & \text { 'watch' } & \text { ni-y-ee[káraang-ire] } & \text { 'fry for' }\end{array}$

(194) Imperative $p l$ 'you $(p l) \ldots$ !'

\begin{tabular}{|c|c|c|}
\hline $\mathrm{mu}[\mathrm{ly}$-é] & 'eat' & mu[nyw-é] \\
\hline$[\beta$ ék-e] & 'shave' & $\mathrm{mu}[\mathrm{r}$ 'é $\beta-\mathrm{e}]$ \\
\hline mu[ßukúl-e] & 'take' & mu[karááng-e] \\
\hline mu[saambúl-e] & 'de-roof' & $\mathrm{mu}$ [lomálom-e] \\
\hline
\end{tabular}


(195) Imperative $p l$-initial stems 'you (pl) ... !'

$\begin{array}{llll}\text { mw[aák-e] [O] } & \text { 'weed' } & \text { mw[íts-e] [O] } & \text { 'come' } \\ \text { mw[aanix-e] } & \text { 'set out' } & \text { mw[aasyáák-e] } & \text { 'split' }\end{array}$

(196) Imperative Il $V C V$ stems [W] 'you $(p l) \ldots$ !'

mw[áák-e] 'weed' mw[1́mb-e] 'sing'

(197) Imperative $p l+O P$ 'you $(p l) \ldots$ him!'

$\begin{array}{llll}\text { mu-mú[xw-é] } & \text { 'pay dowry' } & \text { mu-mú[ßék-e] } & \text { 'shave' } \\ \text { mu-mú[réeß-e] } & \text { 'ask' } & \text { mu-mú[lésher-e] } & \text { 'forgive' } \\ \text { mu-mú[léxuul-e] } & \text { 'release' } & \text { mu-mú[téex-er-e] } & \text { 'cook for' } \\ \text { mu-mú[l'ingeer-e] } & \text { 'watch' } & \text { mu-mú[ßótooxan-e] 'go around' }\end{array}$

(198) Imperative Im $+O P$ V-initial 'you $(p l) \ldots$ him!'

mu-mw['ir-e] 'kill' mu-mw['ímb-ir-e] 'sing for'

mu-mw[áándiik-ir-e] 'write for'

(199) Imperative Il $+O P_{\text {Refl }}[\mathrm{O}]$ ' ... yourselves!'

$\begin{array}{llll}\text { mw-ee[ry-é] } & \text { 'fear' } & \text { mw-ee[ßék-e] } & \text { 'shave' } \\ \text { mw-ee[réé } \beta-e] & \text { 'ask' } & \text { mw-ee[fúmir-e] } & \text { 'stab' } \\ \text { mw-ee[léxuul-e] } & \text { 'release' } & \text { mw-ee[ßóólol-e] } & \text { 'untie' } \\ \text { mw-ee[káraang-ir-e] } & \text { 'fry for' } & \text { mw-ee[káángulul-e] } & \text { 'untie' }\end{array}$

(200) Imperative $p$ I $O P_{\text {Refl }}[\mathrm{W}]$ '... yourselves!'

mw-ee[ßék-e] 'shave' mw-er

mw-ee[léxul-e] 'release' mw-ee[ßóólol-e] 'untie'

mw-ee[káraang-ir-e] 'fry for' mw-ee[káángulul-e] 'untie'

\subsection{Pattern 4c}

(201) Hesternal Perfective Negative [O] 'he did not ...'

sí-y-a[1-iire] tá 'eat'

sí-y-a[teex-ere] tá 'cook'

sí-y-a[fuundiix-e] tá 'knot' sí-y-a[kon-ere] tá 'sleep'

sí-y-a[karaang-ire] tá 'fry'

ś-y-a[liingeer-ere] tá 'watch'

(202) Hesternal Perfective Negative $V$-initial [O] 'he did not ...'
sí-y[eemb-ere] tá
'sing'
ś́-y[eexaal-e] tá
'sit'
sí-y[aandiik-ire] tá 'write'
ś́-y[eeßiiriir-e] tá
'forget' 
(203) Hesternal Perfective Negative + OP [O] 'he did not ... him' sí-y-a-mú[r-iire] tá 'fear' sí-y-a-mú[ßék-ere] tá sí-y-a-mú[réeß-ere] tá 'ask' sí-y-a-mú[ßúkuul-e] tá 'take' sí-y-a-mú[léxuul-ire] tá 'release' śi-y-a-mú[téex-eer-e] tá 'cook for' ś́-y-a-mú[ringaal-ire] tá 'watch'

(204) Hesternal Perfective Negative + OP V-initial [O] 'he did not ... him' sí-y-a-mw[írir-e] tá 'kill' sí-y-a-mw['ímb-iir-e] tá 'sing for' ś́-y-a-mw[áándiik-ire] tá 'employ'

(205) Hesternal Perfective Negative $+O P_{\text {Reft }}[\mathrm{O}]$ 'he did not ... himself' $\begin{array}{llll}\text { ś́-y-e[r-1́re] tá } & \text { 'fear' } & \text { sí-y-e[ßék-ere] tá } & \text { 'shave' } \\ \text { ś1-y-e[fwáál-ire] tá } & \text { 'dress' } & \text { sí-y-e[fúmiir-e] tá } & \text { 'stab' } \\ \text { sí-y-e[ßóólool-e] tá } & \text { 'untie' } & \text { sí-y-e[léxuul-ire] tá } & \text { 'release' } \\ \text { ś-y-e[língaal-ire] tá } & \text { 'watch' } & \text { sí-y-e[y-ándiik-iir-e] tá } & \text { 'write for' }\end{array}$

(206) Hodiernal Perfective Negative 'he did not ..., 32

$\begin{array}{llll}\text { s-áa[l-iire] tá } & \text { 'eat' } & \text { s-áa[kon-ere] tá } & \text { 'sleep' } \\ \text { s-áa[reeß-ere] tá } & \text { 'ask' } & \text { s-áa[teex-ere] tá [O] } & \text { 'cook' } \\ \text { s-áa[ßukuul-e] tá [O] } & \text { 'take' } & \text { s-áa[karaang-ire] tá } & \text { 'fry' } \\ \text { s-áa[fuundiix-e] tá } & \text { 'knot' } & \text { s-áa[liingeer-ere] tá } & \text { 'watch' }\end{array}$

(207) Hodiernal Perfective Negative V-initial stems [O] 'he did not ...'
sí-y[eemb-ere] tá
'sing' sí-y[eexaal-e] tá
'sit'
sí-y[aasyaak-ire] tá
'split' ś-y[eeßiriir-e] tá
'forget'

(208) Hodiernal Perfective Negative $+O P[\mathrm{O}]$ 'they did not ... him'

\begin{tabular}{|c|c|c|}
\hline 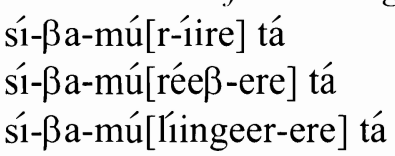 & $\begin{array}{l}\text { 'fear' } \\
\text { 'ask' } \\
\text { 'watch' }\end{array}$ & 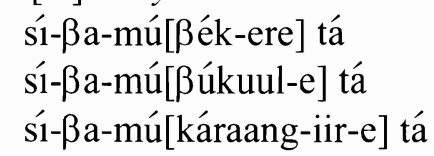 \\
\hline
\end{tabular}

\footnotetext{
32 These forms were collected once from Wabala. The elicited examples have the same stem tone patterns as Okumu, but the tone on the prefix sounds inexplicably like level $\mathrm{H}$ and not the expected falling tone from underlying $\mathrm{H}+\varnothing$.
} 
(209) Hodiernal Perfective Neg. + OP V-initial [O] 'they did not ... him'

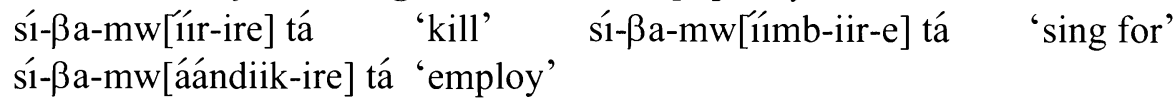

(210) Hodiernal Perfective Negative $+O P_{\text {Refl }}[\mathrm{O}]$ 'he did not ... himself'

sí-y-ee[r-írre] tá

sí-y-ee[réé $\beta$-ere] tá

sí-y-ee[ßóólool-e] tá

sí-y-ee[língaal-ire] tá 'fear'

'ask'

'untie'

'watch' sí-y-ee[ßék-ere] tá

sí-y-ee[fúmiir-e] tá

sí-y-ee[léxuul-ire] tá

ś-y-ee[y-ándiik-iir-e] tá 'shave'

'stab'

'release'

'write for'

\section{REFERENCES}

Bickmore, Lee. 2000. "Downstep and fusion in Namwanga". Phonology 17: 297333.

Bird, Charles. 1966. Aspects of Bambara Syntax. UCLA, PhD. dissertation.

Clements, George N. \& Kevin Ford. 1979. "Kikuyu tone shift and its synchronic consequences". Linguistic Inquiry 10: 179-210.

Crane, Thera. 2009. "Phrase formation and downstep in Shekgalagari." Paper presented at the $83^{\text {rd }}$ Annual Meeting of the Linguistic Society of America, San Francisco.

Dalgish, Gerald M. 1986. “/-a-/ reduction phenomena in Luyia". Studies in African Linguistics 17: 155-176.

Hyman, Larry. 2001. "Privative tone in Bantu". Cross-linguistic studies of Tonal Phenomena, ed. by Shigeki Kaji. Tokyo: ILCAA. Pp. 237-257. 
Hyman, Larry. 2003. "Segmental phonology". The Bantu Languages, ed. by Derek Nurse \& Gérard Philippson. New York: Routledge. Pp. 42-58.

Isac, Daniela \& Charles Reiss. 2008. I-Language: An Introduction to Linguistics as Cognitive Science. New York: Oxford University Press.

Kim, Yuni \& Mary Paster. 2007. "Downstep in Tiriki”. UC-Berkeley \& Pomona College, Ms.

Leung, Elizabeth. 1991. The Tonal Phonology of Llogoori: A Study of Llogoori Verbs (Working Papers of the Cornell Phonetics Laboratory, 6). Ithaca, NY: CLC Publications.

Marlo, Michael. 2007. The verbal tonology of Lumarachi and Lunyala: two dialects of Luluyia (Bantu, J.30, Kenya). University of Michigan, PhD. dissertation.

Marlo, Michael. 2008. "Reversal and predictability in Luyia verbal tone systems". Paper presented at the Annual Conference on African Linguistics 39, University of Georgia.

Marlo, Michael. to appear. "Khayo verbal tonology”. Africana Linguistics XV.

Odden, David. 1982. "Tonal phenomena in Kishambaa". Studies in African Linguistics 13: 177-208.

Odden, David. 1989. "Predictable tone systems in Bantu". Autosegmental studies on pitch accent systems, ed. by Harry van der Hulst \& Norval Smith. Dordrecht: Foris. Pp. 225-251.

Odden, David. 2000. "Opacity and ordering: H-deletion in Kikerewe". The Linguistic Review 17: 323-335.

Odden, David. 2009. "Tachoni verbal tonology". Language Sciences 31: 305324. 
Schuh, Russell. 1998. A Grammar of Miya. Berkeley: University of California Press.

Stevick, Earl. 1969. "Tone in Bantu”. International Journal of American Linguistics 35(4): 330-341.

Center for Advanced Study of Language Box 25

College Park, MD 20742-0025

michaelrmarlo@gmail.com [received November 13, 2008, accepted December 27, 2008] 
